\title{
Conceptual Models of Flow through a Heterogeneous, Layered Vadose Zone under a Percolation Pond
}

\author{
Kristine Baker \\ Larry Hull \\ Jesse Bennett \\ Shannon Ansley \\ Gail Heath
}

February 2004 
INEEL/EXT-03-01679

\title{
Conceptual Models of Flow through a Heterogeneous, Layered Vadose Zone under a Percolation Pond
}

\author{
Kristine Baker \\ Larry Hull \\ Jesse Bennett \\ Shannon Ansley \\ Gail Heath
}

February 2004

Idaho National Engineering and Environmental Laboratory

Environmental Monitoring Program

Idaho Falls, Idaho 83415

Prepared for the

U.S. Department of Energy

Assistant Secretary for Environmental Management

Under DOE Idaho Operations Office

Contract DE-AC07-99ID13727 



\begin{abstract}
Understanding how water and solutes move through the vadose zone is necessary to make effective remedial action decisions where contaminants were spilled or leaked at the ground surface or were buried in shallow land-disposal sites. In layered, heterogeneous systems, high contrasts in hydraulic conductivity can lead to formation of perched water zones, and enhanced lateral spread of contamination. Two conceptual models are considered solute for migration through the vadose zone. In the diffuse flow conceptual model, perched water zones accumulate until the head over the perching layer becomes sufficient to drive the infiltration through the perching layer. In the preferential flow conceptual model, perched water moves laterally until a path around the perching layer is encountered. Preferential flow paths can enhance contaminant migration because greater moisture saturation leads to higher advective velocities, and the preferential flow paths bypass low permeability layers with higher sorption capacity. Monitoring wells and instrumented boreholes were installed around a newly constructed industrial-waste percolation pond and an ephemeral river that lie over a 150-m-thick layered vadose zone. Background data gathered before discharge to the pond began show the presence of at least one, and possibly two, deep perched zones. The shallower zone, at approximately $45-\mathrm{m}$ below land surface (bls), extends $800-\mathrm{m}$ south of the river to the vicinity of the pond. There is a deeper zone at $90-\mathrm{m}$ bls, southeast of the pond, in the direction away from the river. The river last contained water in May 2000, two years before data collection began in the summer of 2002. Two significant implications of this are (1) perched water persists for several years in the absence of surface recharge, and (2) lateral migration of perched water extends on the order of a kilometer from the river. Hydrological data collected and analyzed since discharge to the pond began in October 2002 indicate a high degree of spatial variability within the shallow subsurface, resulting in directional flow in a southern direction from discharge to the south cell and a northern direction from discharge to the north cell. Water arrival was observed at deeper locations before shallower ones, and lateral transport was observed not only at basalt/interbed interfaces but also within thick basalt layers. Recharge was observed as deep as $87-\mathrm{m}$ bls and as far away as the Big Lost River 860-m to the north. New perched zones formed at the first alluvium/basalt interface on the southern end of the pond after discharge began to the south cell and at deeper lithologic interfaces where monitoring wells were completed on the northern, southern, and western perimeter of the pond. Preferential flow was found to be the most prevalent type of flow at the Vadose Zone Research Park, in contrast to the current INEEL conceptual model of vadose zone transport that adopts the diffuse flow model for contaminant transport predictions
\end{abstract}




\section{ACKNOWLEDGEMENTS}

Construction and operation of the research park resulted from the work of many. Thanks to Carolyn Bishop and Tim Kaser for calibration and installation of instruments, setting up the data loggers, and the communication system. Thanks to Rick Phillips for developing the data management system. Thanks for field sampling support from Ben Beus, Jeremy Wall, Dave Hawley, Joe Lord, and Amy Millward. Finally, and most significantly, the authors thank Leah Street, manager of INEEL Environmental Monitoring Programs for supporting the VZRP construction and monitoring activities. 


\section{CONTENTS}

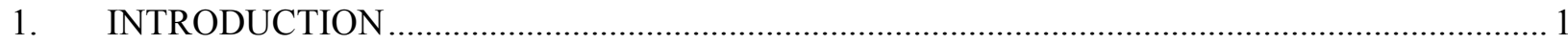

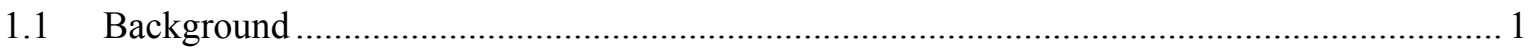

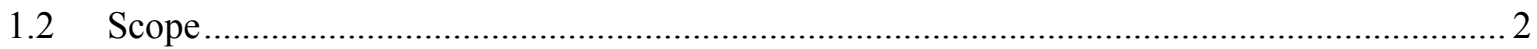

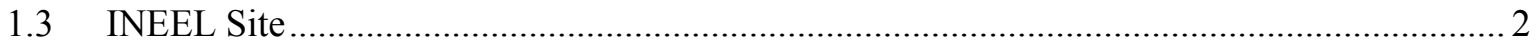

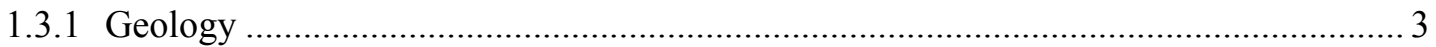

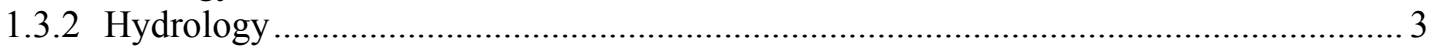

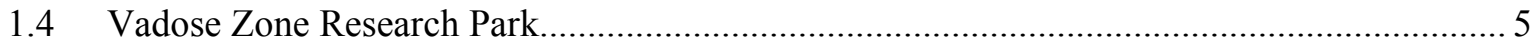

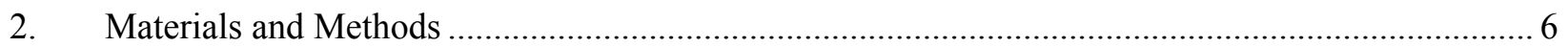

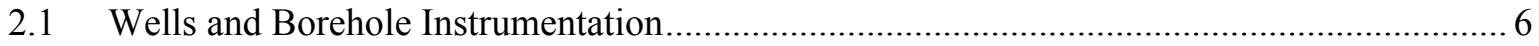

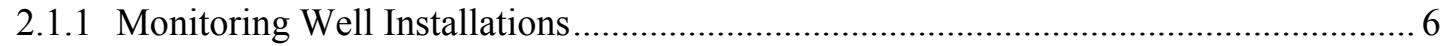

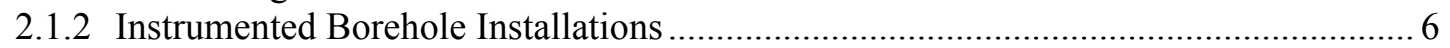

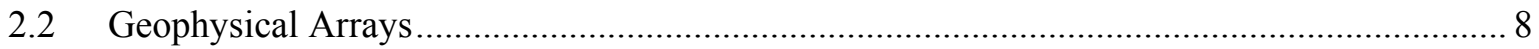

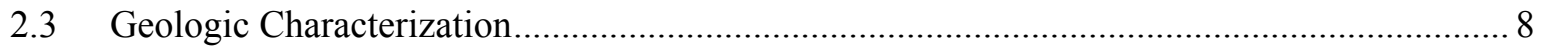

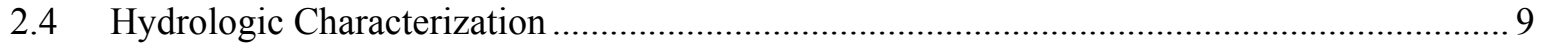

2.4.1 Basic Concepts and Theory of Unsaturated Flow …….............................................. 9

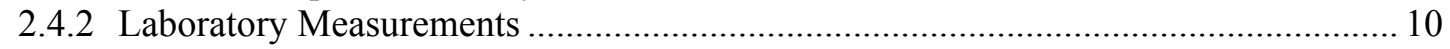

2.5 Hydrology Data Collection and Management................................................................. 10

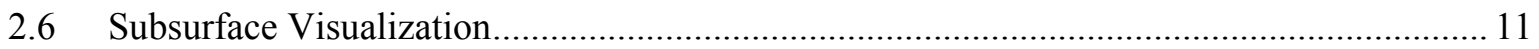

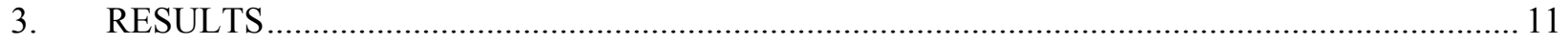

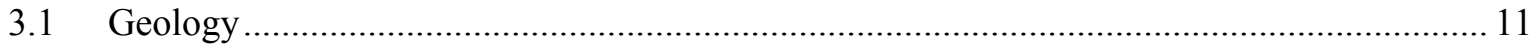

3.1.1 Description of VZRP Site Specific Stratigraphy and Lithology ................................. 11

3.2 Laboratory Measured Interbed Properties....................................................................... 12

3.2.1 Physical Properties ............................................................................................ 12

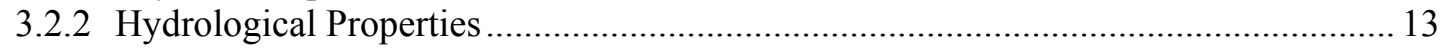

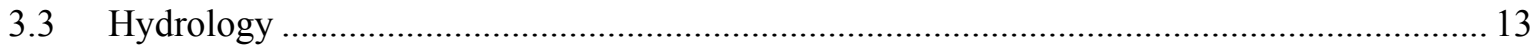

3.3.1 Preinfiltration Subsurface Conditions..................................................................... 13

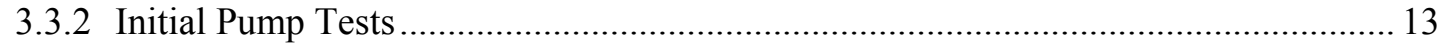

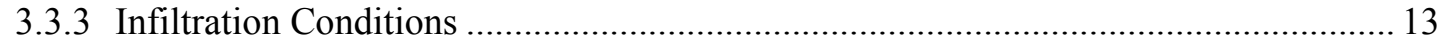

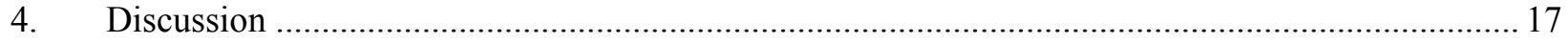

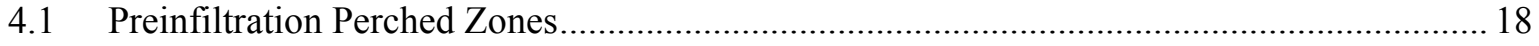

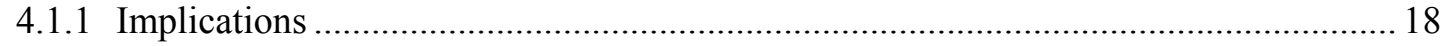

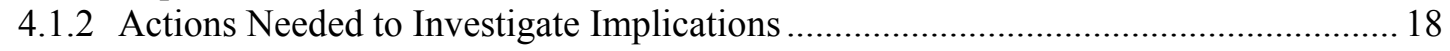

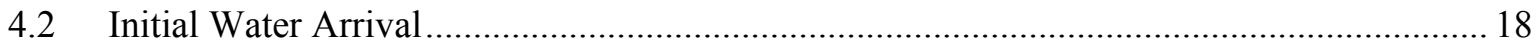

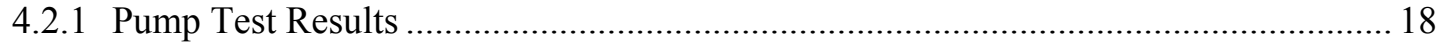

4.2.2 Water Arrival Sequences and Travel Times .......................................................... 19

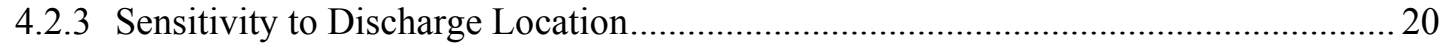




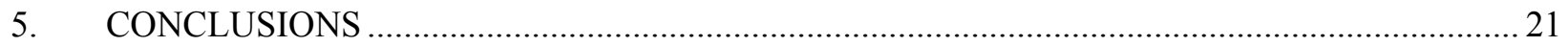

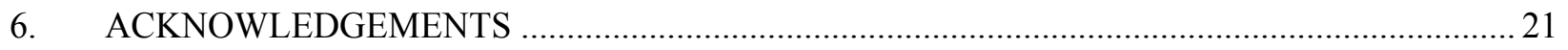

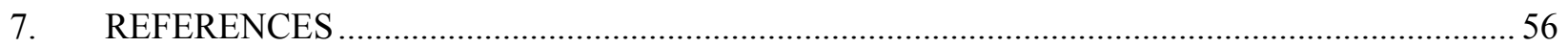

\section{FIGURES}

1. Map of the INEEL, showing the locations of major facilities and the Vadose Zone Research Park at the new INTEC (Idaho Nuclear Technology and Engineering Center) Perc Pond.

2. Map of the INEEL, showing the location of facilities, river gauging stations, and weather stations near the vadose zone research park.

3. Annual total discharge in the Big Lost River at the INEEL diversion dam, upstream from the Vadose Zone Research Park, and at Lincoln Blvd., downstream from the park.

4. Average monthly discharge at the INEEL diversion dam from July 1984 through September 2001.

5. Correlation of infiltration rate with Big Lost River discharge at the INEEL diversion dam

6. Discharge to north and south cells of the new INTEC percolation pond during initial system testing and initial production use of the pond in the summer of 2002 .......

7. Map of the Vadose Zone Research Park, showing the location of aquifer wells and core holes.....26

8. The new percolation pond, showing the extent of ponding in the south cell. .26

9. Instrument bundles were assembled on the land surface and inspected before installation.

10. Instrument strings were measured to ensure that instruments would be installed at the depths selected by the project hydrologist.

11. Instrument packages installed in boreholes at various locations to measure moisture content, potential, and collect water and gas samples from the vadose zone.

12. Moisture sensors planned for installation in sedimentary interbeds were calibrated using INEEL sediments (left).

13. Stratigraphic correlation between instrumented boreholes at the Vadose Zone Research Park. .... 29

14. Subsurface lithology of the Vadose Zone Research Park, visualized using the Environmental Visualization System.

15. Preinfiltration subsurface moisture conditions.

16. Tensiometer data for well 207 , showing first water arrival from early discharge during June 18 through June 27, 2003 while testing pumps 
17. Well 204 tensiometer response to initial water arrival and changes in discharge location for the months of August through October 2002

18. Well 205 tensiometer responses to initial water arrival and changes in discharge location for the months of August through October 2002.

19. Well 198 tensiometer responses to initial water arrival and changes in discharge location for the months of August through October 2002.

20. Well 215 tensiometer responses to initial water arrival and changes in discharge location for the months of August through October 2002..

21. Well 189 advanced tensiometer pressure readings at 31-m bls.

22. Tensiometer and water content sensors, showing response to first water arrival in well 198 at 37-m below land surface within the C-D interbed on September 11, 2002.

23. Tensiometer and water content sensors, showing response to first water arrival in well 204 at 46-m below land surface in the C-D interbed on September 10, 2002.

24. Tensiometer and water content sensors showing response to first water arrival in well 205 at approximately 40-m below land surface in the C-D interbed on September 2, 2002.

25. Comparison between tensiometer (AT) pressure head data and water level (WL) sensor data in the instrumeneted borehole 205 and the perched water monitoring well 200 during rapid infiltration.

26. Comparison between tensiometer (AT) and water level (WL) sensor pressure head data in the instrumented borehole 198 and vadose zone monitoring well 197 during slow infiltration.

27. Hydraulic conditions after one month (October 31, 2002) of continuous discharge to the south cell at the Vadose Zone Research Park percolation pond.

28. Perched water levels measured in vadose zone monitoring wells at the Vadose Zone Research Park March 2003.

29. Water arrival sequence beneath the Vadose Zone Research Park percolation pond for borehole 204, based on tensiometer data collected from July 1, 2002 through October 31, 2002.

30. Water arrival sequence beneath the Vadose Zone Research Park percolation pond for borehole 215, based on tensiometer data collected from July 1, 2002 through October 31, 2002.

31. Grouped lithology water arrival dates as a function of lateral distance from the center berm of the pond for the alluvium/basalt interface, the B-BC interbed, and the C-D interbed for wells $198,204,205$, and 215 .

32. Example of changes in hydraulic pressure possibly due to flushing of fines from large pores during rapid infiltration or encountering fast pathways.

33. Example of changes in hydraulic pressure possibly due to flushing of fines from large pores during rapid infiltration or encountering fast pathways. 
34. Example of changes in hydraulic pressure possibly due to flushing of fines from large pores during rapid infiltration or encountering fast pathways.

35. Example of changes in hydraulic pressure possibly due to flushing of fines from large pores during rapid infiltration or encountering fast pathways.

\section{TABLES}

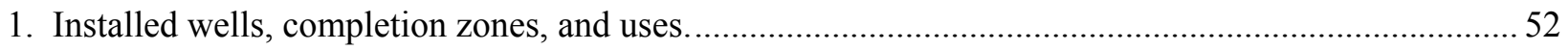

2. Water arrival times to various instruments installed at depth near the percolation pond. ....................54 


\section{ACRONYMS}

$\begin{array}{ll}\text { AT } & \text { tensiometer, or advanced tensiometer } \\ \text { 2-D } & \text { 2-dimensional } \\ \text { bls } & \text { below land surface } \\ \text { ERT } & \text { electrical resistivity tomography } \\ \text { EVS } & \text { Environmental Visualization System } \\ \text { INTEC } & \text { Idaho Nuclear Technology and Engineering Center } \\ \text { ID } & \text { inside diameter } \\ \text { OD } & \text { outside diameter } \\ \text { TRA } & \text { Test Reactor Area } \\ \text { DOE } & \text { U.S. Department of Energy } \\ \text { UZF } & \text { unsaturated-zone flow } \\ \text { VZRP } & \text { Vadose Zone Research Park } \\ \text { VEA } & \text { vertical electrode array } \\ \text { WC } & \text { water content } \\ \text { WL } & \text { water level }\end{array}$




\section{Conceptual Models of Flow through a Heterogeneous, Layered Vadose Zone under a Percolation Pond}

\section{INTRODUCTION}

Past industrial practices at U.S. Department of Energy (DOE) facilities included discharge of liquid wastes to infiltration ponds and cribs, burial of solid wastes in landfills, and inadvertent spills and leaks of contaminants. These planned and unplanned disposal activities have resulted in the presence of contaminated soil and perched water in the vadose zone. Over the past decade or more, DOE has worked to remediate these contaminated areas so that they do not pose a risk to future generations. The only apparent options available for much of the radionuclide and metal contamination in the vadose zone are to leave it in place, or to excavate and move it to a subsurface repository. Either way, the contamination remains in the vadose zone where long-term stewardship is required. We currently lack understanding of movement of water and contaminants through heterogeneous, layered unsaturated sediment and rock so that protective remedial actions can be selected (National Research Council 2000). Of particular concern is water transport through perched water zones and fast pathways in fractured rock. Sedimentary deposits can retard contaminant transport by sorbing chemicals onto the solid matrix. Fractured rock presents much less surface area for sorption, and consequently less ability to retard contaminant movement. In addition, there is not yet a widely accepted theory or model for preferential flow in the vadose zone, which causes major disagreements between model predictions and measurements (Nimmo et al. 2002). Formation of perched water increases hydraulic conductivity within these deposits, reducing chemical residence time and sorption. Perched water zones have the potential to enhance lateral spreading of contaminants from source areas. Fracture networks within rock layers are difficult to characterize using traditional methods and are often neglected in transport predictions. Hence, current vadose zone transport models fail to capture the potential for rapid transport through fractured rock. Long-term stewardship requires better understanding of mechanisms contributing to the formation, longevity, and transport within perched water zones and a means to characterize and incorporate fracture networks into vadose zone transport models.

\subsection{Background}

Understanding the processes involved in the formation of perched water in the unsaturated zone is important in predicting contaminant transport in the subsurface. Perched water in the vadose zone occurs in regions where the vertical flux of water exceeds the ability of the formation to transmit the water. Movement of water through perched zones takes place either by (a) increasing the hydraulic head enough to force water through the underlying perching layer, or by (b) creating a hydraulic gradient permitting lateral flow of water on top of the perching layer until the low permeability layer pinches out or becomes more permeable. We refer to these two conceptual models as the diffuse flow model and the preferential flow model, respectively. The preferential flow model is of particular concern in subsurface contaminant transport because it can lead to extensive spreading of contamination as water moves laterally in search of more permeable zones, and can accelerate transport along preferential flow paths because water content is closer to saturation and materials with higher sorbing capacity are bypassed.

The conceptual model most prevalent at the INEEL adopts diffuse flow for vadose zone flow and transport. In a computer model of the vadose zone under the Idaho Nuclear Technology and Engineering Center (INTEC) facility, a large number of discontinuous interbeds were grouped into three effective interbeds continuous under the INTEC facility (Schafer et al. 1997). The model predicted significant lateral spread of perched water zones under INTEC to develop sufficient hydraulic gradient to drive recharge through the interbed. At the Radioactive Waste Management Complex (RWMC), two 
sedimentary interbeds underlie most of the facility and represent a fairly continuous barrier to vertical flow and transport (Magnuson and Sondrup 1998). Risk management decisions at the INEEL are based on a conceptual model of diffuse flow through the vadose zone with significant contact between sedimentary interbeds and infiltration.

A number of recent investigations have been conducted at the INEEL, however, that suggest that water may move along more preferential flow paths. These studies suggest a plume of water flowing through the vadose zone primarily in a vertical direction until reaching the first alluvium/basalt interface, at which time lateral transport occurs until encountering preferential flow paths within the basalt. Transport through the subsequent intermittent layers of sedimentary interbeds and fractured basalt layers is conceptualized as a complex mixture of vertical transport through high permeability fractured basalt and lateral transport along interbed/basalt interfaces. Vertical water flow along preferential flow paths within fractured basalt has resulted in water arrival at deep zones befoe arrival in shallower zones (Dunnivant et al. 1997). Perched zones within both interbed and basalt layers have formed as a result of rapid infiltration from natural and artificial recharge, wastewater disposal, or aging pipelines. The perched zones are in most cases associated with sedimentary interbeds or dense basalt layers within individual basalt facies. Lateral transport has been observed within the perched zones on the order of meters per day under both natural and artificial recharge. Lateral transport within these zones has been observed to be as extensive as 100-m from the recharge location at the RWMC (Hull and Bishop 2003), 800-m from the source area at Test Reactor Area (Arnett et al. 1996), and over a kilometer at spreading areas west of the RWMC (Nimmo et al. 2002). Short-range lateral flow has also been observed at vesicular lenses, central fracture zones, and at rubble zones within basalt layers (Faybishenko et al. 2000). It is assumed that once rapid infiltration into the subsurface is discontinued, perched zones will rapidly drain, suspending extensive lateral transport from the recharge locations (DOE/ID 1999).

\subsection{Scope}

In this report, we describe the Vadose Zone Research Park, a research site built at the INEEL (VZRP), developed and instrumented to gather data on the movement of water and solutes through the vadose zone. Monitoring wells have been installed to record water levels and collect water samples from perched water zones. Boreholes have been instrumented with tensiometers, water content sensors, and suction lysimeters to record matric potential, water content, and to collect water samples from unsaturated basalt and sediment. Changes in water distribution in a complex, layered, vadose zone were studied as the subsurface wetted up when discharge to a new infiltration pond began. We discuss hydrologic changes that were measured at the site during the first year of operation, compare results to our current conceptual model for vadose zone transport at the INEEL, and discuss implications of the results and actions needed to investigate these implications further.

\subsection{INEEL Site}

The INEEL is located in Southeast Idaho (Figure 1) and occupies $2,305 \mathrm{~km}^{2}$ in the northeast region of the Snake River Plain. The surface of the INEEL is a relatively flat, semiarid, sagebrush desert. Elevations on the INEEL range from 1,460-m in the south to $1,802-\mathrm{m}$ in the northeast, with an average elevation of 1,524-m above sea level. The INEEL's climate is arid to semiarid, with average annual precipitation of $22 \mathrm{~cm}$ (Clawson et al. 1989). Winter snowfall normally occurs from November through April and ranges between 17.3 and $151.6 \mathrm{~cm}$ per year, with an annual average of $70.1 \mathrm{~cm}$. Potential annual evaporation is $109 \mathrm{~cm}$, with about $80 \%$ of this occurring between May and October. Evapotranspiration is estimated to be between 15 and $23 \mathrm{~cm}$ per year, or four to six times less than the

\footnotetext{
${ }^{\text {a }}$ All figures are presented in Section 6, beginning on page 22.
} 
potential evaporation. Periods when the greatest quantity of precipitation water is available for infiltration (late winter to spring) coincide with periods of relatively low evapotranspiration rates.

\subsubsection{Geology}

The INEEL is on the Eastern Snake River Plain, a north-east trending structural basin about $325 \mathrm{~km}$ long and 80 to $110 \mathrm{~km}$ wide. The plain is underlain by a layered sequence of Tertiary and Quaternary volcanic rocks and sedimentary deposits (Anderson and Lewis 1989). Volcanic rocks in this sequence consist of basaltic lava flows and cinder beds. During periods of volcanic quiescence, fluvial, lacustrine, and eolian sediments were deposited. Alternating periods of volcanic activity and sediment deposition formed a complex sequence of layers. The basalt units range from vesicular to massive with horizontal and vertical fracture patterns.

\subsubsection{Hydrology}

\subsubsection{Surface Water}

Surface water at the INEEL consists mainly of streams originating in intermountain valleys to the northwest that flow out onto the Snake River Plain. Most of the INEEL lies in a closed topographic basin into which these surface streams drain, and the streams terminate in playas where the water infiltrates to the Snake River Plain Aquifer. The Big Lost River is the major surface water feature on the INEEL. Its upstream waters are impounded and regulated by Mackay Dam, $6 \mathrm{~km}$ north of Mackay, Idaho. Below the dam, the river flows southeastward past Arco, Idaho and onto the Eastern Snake River Plain. The Big Lost River enters the INEEL from the west (Figure 1), and then flows northeast across the site to terminate in the Big Lost River playas near Test Area North. The Big Lost River is an intermittent stream, and flow in the stream is significantly affected by irrigation usage. In 1958, a diversion dam was constructed on the INEEL to divert part of the flow out of the main channel to spreading areas (playa lakes) to reduce the threat of floods to INEEL facilities. The river passes about $800-\mathrm{m}$ north of the new INTEC percolation pond (Figure 2).

Stream flow gauging stations are maintained by the U.S. Geological Survey along the Big Lost River upstream of the VZRP but below the diversion dam (Station 13132520) and downstream of the VZRP at Lincoln Boulevard Bridge (Station 13132535) (Figure 2). Flow in the river on the INEEL site is irregular, reflecting significant upstream irrigation consumption, particularly in dry years. Since 1984, there have been two periods when the river has flowed at least part of the year (Figure 3), from July 1984 to July 1987, and again from June 1995 to May 2000. Between July 1987 and June 1995, there were only two months, in 1993, when there was water in the river at the Diversion Dam. The average monthly discharge shows that the highest monthly flows are in the late spring and early summer, with the lowest flow in August, during the peak irrigation season (Figure 4). In wet years, flow again picks up in the river after the end of the irrigation season.

Discharge at the Lincoln Boulevard bridge is lower than the discharge at the INEEL Diversion Dam (Figure 2) due to infiltration along the 17.22-km stretch of river between these two gauging stations (Figure 3). Infiltration rates along this stretch were estimated to range from 61,324 to $64,925 \mathrm{~m}^{3} \mathrm{month}^{-1}$ $\mathrm{km}^{-1}$ by the U. S. Geological Survey (Bennett 1990). When the flow is very low at the Diversion Dam, it does not reach the Lincoln Boulevard bridge, and there is a 1 to 1 correlation between flow at the Diversion Dam and infiltration (Figure 5). Once river flow exceeds the infiltration capacity of the channel, water begins to arrive at Lincoln Boulevard bridge. Infiltration increases slightly with discharge, with an increase of $0.004 \mathrm{~m}^{3}$ month $^{-1} \mathrm{~km}^{-1}$ for a $1 \mathrm{~m}^{3}$ month $^{-1}$ increase in discharge. The base infiltration rate of the channel is on the order of $51,000 \mathrm{~m}^{3} \mathrm{month}^{-1} \mathrm{~km}^{-1}$ (Figure 5).

The variation in flow in the Big Lost River indicates that there should be a highly variable input to the vadose zone from this source. There will be short-term fluctuations within the year during wet years, 
and long-term fluctuations between periods of wet years and dry years. This will provide a large amount of information over time on the dynamics of perched water formation and drainage.

\subsubsection{INTEC Percolation Pond}

A new percolation pond was constructed at the INEEL in 2000 as part of a remedial action to prevent the migration of contaminants in the vadose zone under the INTEC to the aquifer (DOE/ID 1999). The existing industrial wastewater pond was located immediately adjacent to the INTEC facility, and received between 3,785 and $5,700 \mathrm{~m}^{3}$ day $^{-1}$. The new pond was constructed $3 \mathrm{~km}$ southwest of the facility (Figure 2) to permit the vadose zone under INTEC to drain, thus removing a significant driving force for migration of contaminants through the vadose zone. The pond consists of two square cells, a south cell, and a north cell, each 76-m on a side. Approximately on an annual basis, flow is alternated between cells to permit algae and plant growth in the ponds, which slows infiltration, to die off and reestablish hydraulic conductivity.

Periodic releases to the pond occurred while testing pump performance in the summer of 2002 (Figure 6). These periodic discharge events lasted from one to four days and alternated between cells (north and south) at flux rates ranging from 114 to $3,785 \mathrm{~m}^{3} \mathrm{day}^{-1}$. Continuous high volume discharge of water to the south cell of the pond from the INTEC facility began October 5, 2002 at a rate of approximately $3,785 \mathrm{~m}^{3}$ day $^{-1}$. After about a year of operation, continuous discharge was switched from the south cell to the north cell on July 31,2003. Water discharged to the percolation pond is mainly cooling water, but it also contains wastewater generated from regeneration of ion exchange columns and reverse osmosis units. The water chemistry changes significantly, depending on the process activities in the plant. Electrical conductivity of the discharge water varies from approximately $300 \mu \mathrm{S} \mathrm{cm}^{-1}$ to spikes as high as $3,000 \mu \mathrm{S} \mathrm{cm}^{-1}$ every 10 to 12 hours when the INTEC reverse osmosis units are regenerated. Mean water temperature of the INTEC wastewater at the discharge point in the pond is $21^{\circ} \mathrm{C}$.

The infiltration pond receives water from an industrial waste stream with fairly constant water use throughout the year. The water flow to the pond is expected to be fairly constant in time and in volume. We expect annual switches between the north and south cells, which may have some effect on perched water zones as the location of surface recharge changes slightly. The steady-state infiltration at the pond provides a constant input to the vadose zone and provides opportunity to perform tracer tests and validate field instrumentation under relatively static conditions.

\subsubsection{Vadose Zone}

An extensive vadose zone exists at the INEEL, ranging in thickness from $61-\mathrm{m}$ in the north at Test Area North to greater than 274-m near the southern INEEL boundary. The vadose zone consists of surficial sediments, relatively thin horizontal basalt flows, and occasional inter-bedded sediments (Irving 1993). Surface sediments in the vadose zone include clays, silts, sands, and gravels. Thick surficial deposits of clays and silts are found in the northern part of the INEEL, but the deposits decrease in thickness to the south where basalt is exposed at the topographic surface in some locations. Approximately $90 \%$ of the vadose zone is composed of thick sequences of inter-fingering basalt flows. These sequences are characterized by large void spaces resulting from fissures, rubble zones, lava tubes, undulatory basalt-flow surfaces, and fractures. Sedimentary interbeds found in the vadose zone consist of sands, silts, and clays and are generally thin and discontinuous. Sediments may be compacted because of subsequent overburden pressures.

\subsubsection{Perched Vadose Zone Water}

Perched water at the INEEL forms when a layer of dense basalt or fine sedimentary materials occurs with a hydraulic conductivity that is sufficiently low, so that downward movement of infiltrating 
water is restricted. Once perched water develops, lateral movement of the water can occur, perhaps by up to hundreds of meters. When perched water accumulates, the hydraulic pressure head increases, and water flows through the less permeable perching layer and continues its generally vertical descent. If another restrictive zone is encountered, perching again may occur. The process can continue, forming several perched water bodies between the land surface and water table. The volume of water contained in perched bodies fluctuates with the amount of recharge available from precipitation, surface water, and anthropic sources such as evaporation ponds. Perching behavior tends to slow the downward migration of percolating fluids that may be flowing rapidly under transient near-saturated conditions through the vadose zone. Historically, perched water has been found beneath the RWMC, ANL-W, Test Reactor Area (TRA), and INTEC.

\subsection{Vadose Zone Research Park}

A new wastewater percolation pond was constructed approximately $3-\mathrm{km}$ southwest of the INTEC facility. The 3-km² Vadose Zone Research Park (VZRP) surrounding the pond was established in 2001 to study the subsurface hydrology and geochemistry of a relatively undisturbed and uncontaminated area. The research park includes the INTEC percolation pond and the Big Lost River, providing a continuous recharge source from the pond and an intermittent recharge source from the river. Monitoring wells and instrumented boreholes were installed around the perimeter of the pond, on both sides of the Big Lost River, and along a transect between the two (Figure 7). Figure 8 is an aerial view of the VZRP percolation pond (south cell), showing initial ponding shortly after discharge began October 5, 2002 to the south cell of the pond.

The VZRP provides researchers with a unique opportunity to conduct field scale experiments to develop improved and innovative theories and techniques for describing fluid and contaminant movement in partially saturated media. Because the geology at the VZRP is similar to INTEC and the TRA where contaminant migration through the vadose zone is of concern for making remedial action decisions, knowledge gained from the VZRP will be directly applicable to INEEL cleanup. Some important research needs that can be addressed at the VZRP are (a) hydraulic spreading mechanisms in the alluvium and at the alluvium/basalt interface, (b) mechanisms causing perched water at sedimentary interbeds, (c) contributions of fast flow paths for water and contaminant movement in the vadose zone, (d) contribution of deep infiltration to aquifer recharge, (e) contaminant retardation capacity of alluvium, basalt, and sedimentary interbeds, and (f) vadose zone fluid travel time estimates as a function of flow rate in the Big Lost River.

Work began on developing the VZRP in January 2000 and was completed in August 2001. Well construction included five aquifer-monitoring wells, ten perched-water monitoring wells completed in alluvium, thirteen vadose-zone monitoring wells, nine instrumented boreholes, and three geophysical boreholes (Table 1). Most of the holes were drilled using a Foremost DR 24 dual-rotary reverse circulation Barber-style drilling rig with down-hole air hammer. Other drilling rigs included a Schramm drill reverse circulation rig, a Borart-Longyear portable core rig, and an Acker Soil Max Drill. Three holes were continuously cored from the shallowest basalt flow (approximately 20 -m below land surface) to the top of the aquifer (150-m below land surface) to collect geological characterization information. Split spoon samples were collected from a sedimentary interbed approximately $45-\mathrm{m}$ below land surface (bls) in the boreholes completed with instrumentation. Most wells were video logged, and some of the wells were logged with natural gamma and neutron logging instruments. Table 1 lists the well names, completion zones, primary use, and annular seal of all monitoring wells and instrumented boreholes. Well names in this document correspond to the "alias" name listed in column 2 of Table 1. 


\section{MATERIALS AND METHODS}

This section discusses the monitoring installations in the field, the instruments used to collect data, and other investigations conducted to characterize the vadose zone near the new INTEC percolation pond.

\subsection{Wells and Borehole Instrumentation}

Well installation began in January 2000 with installation of aquifer-monitoring wells to support the Waste-Water Land Application Permit for the pond. Installation of vadose zone monitoring wells and instrumented boreholes began in September 2000. Most of the wells were installed by June 2001. Additional wells have been installed for various purposes since then. Well completion reports for most of the wells drilled at the site have been previously published (INEEL 2002).

\subsubsection{Monitoring Well Installations}

Monitoring wells were constructed at various levels in the vadose zone and in the aquifer. The aquifer monitoring wells were completed at depths between 166 and 172-m bls to provide up-gradient and down-gradient water quality monitoring to assess the impact of the new percolation pond on the aquifer. The vadose zone monitoring wells were installed to observe the development of perched water in the vadose zone. Vadose zone monitoring wells were completed with open casing and a well screen. The wells were completed near interbed/basalt interfaces where perched zones were considered likely to develop. Seven of the 16 wells were completed in alluvium immediately above the first basalt flow at a depth of about 15 to $18-\mathrm{m}$ bls. Eight of the vadose zone wells were completed in basalt, immediately above a laterally extensive sedimentary interbed at a depth of about 43 to $46-\mathrm{m}$ bls. One vadose zone monitoring well is completed at a depth of 76-m bls through the center berm between the north and south pond cells. Three monitoring wells were completed at a depth of about $80-\mathrm{m}$ near the river. Most of the monitoring wells were equipped with an electrode array attached to the outside of the PVC casing for geophysical cross-borehole electrical resistivity tomography (ERT) measurements. MiniTROLL water level sensors (In-Situ, Inc., Laramie, Wyoming) or Druck PDCR submersible pressure transducers (Campbell Scientific, Logan, Utah) were installed in many of the monitoring wells (aquifer and vadose zone) to monitor periodic changes in water pressure and formation of perched zones above the water table. Pressure transducers (Honeywell, Freeport, Illinois) thermocouples (Campbell Scientific, Logan, Utah) and electrical conductivity sensors (Global Water, Gold River, California) were installed in some of the shallow monitoring wells to measure short time-scale changes in perched water.

Additional monitoring wells were installed in the north cell of the ponds at 5.8, 3.5, and 2.0-m bls in July 2003. The boreholes were designated as ICPP-1891, ICPP-1892, and ICPP-1893, respectively. An Acker Soil Max Drill rig with a 10.8-cm hollow stem auger with a wire line sampling system was used to drill the boreholes. The wells were cased with $5.08 \mathrm{~cm}$ inside diameter (ID) PVC, capped on the bottom and screened $30.48 \mathrm{~cm}$ up from the cap to allow water to enter the casing for analysis. Bentonite was poured every $1.5-\mathrm{m}$ from the bottom of the borehole around the borehole annulus as the auger was removed, to seal the casing. The top of the casing was sealed near the surface $(15.2 \mathrm{~cm} \mathrm{bls})$ with bentonite followed by cuttings. Pressure transducers, thermocouples, and electrical conductivity sensors were installed in each of these monitoring wells.

\subsubsection{Instrumented Borehole Installations}

Instrumented boreholes contain multiple packages of instruments to monitor the vadose zone water pressure, moisture, chemistry, and gases near the new percolation pond and Big Lost River. The boreholes were completed with nested bundles of vadose zone monitoring instrument packages that consisted of a water content sensor, suction lysimeter, tensiometer assembly, and gas sampling ports (Figure 9). Specific depths for instrument installation were relative to moisture zones associated with 
fractures, interbeds, and alluvium. Instrument strings were assembled on the surface, and depths were verified before installation to make sure that instruments were installed at planned depths (Figure 10). The tensiometers and lysimeters were completed in a silica sand/silica flour mixture (Figure 11), and the gas probe openings were completed in an adjacent layer of coarse silica sand or alluvial gravel. Granular bentonite was poured down the borehole between each instrument package to provide a seal between lithologic layers and moisture zones. Seven boreholes were drilled to depths ranging from 45 to $52-\mathrm{m}$ bls. Each borehole was equipped with up to 10 bundles of vadose zone monitoring instrument packages. Two deep core holes drilled by the U.S. Geological Survey (214 and 215) were equipped with similar bundles of instrument packages ranging in depth from the first alluvium/basalt interface (approximately $20-\mathrm{m}$ bls) to the capillary fringe (approximately $137-\mathrm{m} \mathrm{bls).} \mathrm{All} \mathrm{sensors} \mathrm{were} \mathrm{calibrated} \mathrm{before} \mathrm{installation.} \mathrm{The}$ sensors are connected to data loggers (Campbell Scientific, Logan, Utah) at data acquisition stations installed at each of the nine vadose zone instrumented boreholes.

\subsubsection{Instrument Packages}

Instrument packages consist of up to four components. Moisture is monitored with tensiometers and water content sensors. Geochemical samples are collected through gas ports and suction lysimeters. The pressure transducer installed in the tensiometer contains a thermocouple permitting the measurement of temperature as well.

\subsection{Advanced Tensiometers}

The tensiometer assembly (also referred to as the Advanced Tensiometer or AT) consists of 2 sections: the pressure sensor assembly and the ceramic cup assembly (Hubbell and Sisson 1998; Sisson et al. 2000). The pressure sensor assembly (Advanced Tensiometer Pressure Sensors, Electronic Engineering Innovations, Las Cruces, NM) consists of a $1.8 \mathrm{~kg}$ weighted $0.9-\mathrm{m}$ long by $1.25 \mathrm{~cm}$ diameter tube that houses a silicone diaphragm $0.72-\mathrm{kPa}$ differential pressure transducer and an analog device temperature chip. A rubber stopper is attached at the bottom of the pressure assembly to seat it in the ceramic cup assembly down borehole. This allows easy removal of the pressure assembly for maintenance and calibration. The ceramic cup assembly is constructed by attaching a 1-bar ceramic porous cup to the bottom of a $15-\mathrm{cm}$-long by $2.5-\mathrm{cm}$-diameter PVC tube. A $2.5-\mathrm{cm}$ inner diameter (ID) access tube (PVC) extending to the surface is attached to the ceramic cup assembly for all tensiometers, except the deepest tensiometer, in each borehole. The deepest tensiometer has a 3.8-cm ID access tube to provide access for periodic neutron logging. Because tensiometer pressure readings are sensitive to changes in barometric pressure (as a function of depth bls), a barometer was installed at the 214 data logger station to obtain data to correct tensiometer readings for barometric pressure fluctuations.

\subsection{Moisture Sensors}

The water content sensors were constructed from commercially available CS505 moisture sensors (Campbell Scientific, Logan, Utah). The sensors were modified to obtain electrode contact with the walls of an open borehole (not cased). The modifications consisted of replacing the metal wave guides with thin copper strips epoxied to Styrofoam pads (Figure 9). The pads were stabilized with PVC plates attached to the CS505 electrical terminals. Moisture sensors were calibrated for either sediment or basalt, depending on the lithology at the planned installation depth (Figure 12). In the well, the pad of each sensor was forced against the borehole wall using a lever arm activated at the surface (Figure 11). The sensors and the lever arms were attached to 12 of the total 76 tensiometers installed to collect moisture retention properties (coupled water content and matric potential data) of the vadose zone material at these depths. 


\subsection{Suction Lysimeters and Gas Sampling Ports}

The suction lysimeters (SoilMoisture Equipment Corp., Goleta, California) consist of a 2-bar porous ceramic cup attached to 5-cm outside diameter (OD) PVC tubing. Two 6.4-mm polyethylene tubes extend from the top of the lysimeter assembly to land surface for sample collection. A vacuum is applied to the air tube, and water migrates into the lysimeter over a period of hours to days. Pressure is applied to the air tube, using nitrogen or argonne gas, to force the water to the surface out of the water tube for sample collection and analysis. The gas sampling ports were also constructed of 6.4-mm polyethylene tubing. Several small-diameter holes $(1.6-\mathrm{mm})$ were drilled in the bottom $0.6-\mathrm{m}$ of the tubing for gas induction.

\subsection{Geophysical Arrays}

Two additional monitoring wells were drilled to approximately $76-\mathrm{m}$ bls, concurrently with installation of the instrumented boreholes. Well 209 was drilled on the west berm of the new percolation pond, while well 201A was drilled on the east berm, both adjacent to the southern cell of the pond. These wells were initially designed to monitor water levels, water quality, and to collect wetting front geophysical data in the subsurface near the new percolation pond. Unfortunately, the casing in these two wells collapsed during well completion; therefore, these wells can only be used to measure ERT data using a vertical electrode array (VEA) attached to the outside of the PVC well casing. A third VEA is installed in well 212, in the center berm of the pond.

Before flooding the site, two surface electrode arrays were installed, extending out from the VEA at well 212 between the cells. Each surface array included 30 electrodes at 6-m intervals. The other VEAs in wells 201A and 209 are located approximately 150-m apart in an east-west direction and 30-m south of the east-west line formed by the surface arrays. This positioned the VEA one on each side of the south percolation pond, approximately $30-\mathrm{m}$ distant from the pond, and at approximately $1 / 3$ of the south extent of the pond. The depths of all three VEA were $70-\mathrm{m}$, and electrodes were placed at $2.5-\mathrm{m}$ intervals.

Various electrical data were available for collection. The significant data that were collected during each time period include Schlumberger sounding/profiling along the surface arrays, common-well and cross well dipole-dipole data, and cross-well horizontal transmitters with vertical dipole receivers. Pole-dipole-like data were also collected, which used a vertical dipole in one VEA, a single electrode in a second well, and the reference electrode was the bottommost electrode in the third VEA. The data collection schedules included a preflood background dataset collected the morning of June 18, 2002. Subsequently data collection intervals were approximately every 5 hours. Continuous cycling over each 24-hour period resulted in 5 to 6 collection intervals per day. Each collection interval started and ended autonomously.

\subsection{Geologic Characterization}

A good understanding of the subsurface geology of the site is necessary to provide the framework for the hydrologic model. Several sources of information were used to construct a 3-D geologic conceptual model of the subsurface. The sources included lithologic logs, paleomagnetic inclination data, down-hole video logs, and borehole geophysical logging techniques that include natural gamma, gammagamma, neutron, and caliper logs. Lithologic logs, borehole geophysical logs, details of well completions, and instrument locations are compiled in the VZRP End of Well Report (INEEL 2002).

Duane E. Champion and Theodore C. Herman of the U.S. Geological Survey, Menlo Park, California measured paleomagnetic inclination in basalt from three core holes within the VZRP $(213,214$, 
and 215). ${ }^{\mathrm{b}}$ Lithostratigraphic descriptions of the complete core record with particular attention given to morphological features representing the upper and lower surfaces of individual basalt flows or flow units defined individual sample locations. Within each basalt flow or flow unit, seven 2.5 -cm subcores oriented perpendicular to the primary core axis were collected and measured for inclination and magnetization intensity. Direction of inclination could not be measured because original core material was not oriented. After removal of secondary magnetization components, remnant inclinations of magnetic minerals within the basalt material of each sample were measured. The mean inclination values and the $95 \%$ confidence limits about the mean formed the basis of basalt flow unit boundaries and consequent correlation of units between the boreholes (McFadden and Reid 1982). Petrographic characteristics visible in hand-sample also aided definition of significant basalt flow boundaries.

\subsection{Hydrologic Characterization}

Once the geologic structure of the site has been determined, material properties relevant to controlling the movement of water must be determined. This section discusses laboratory investigations conducted to gather material property data for unsaturated flow parameters.

\subsubsection{Basic Concepts and Theory of Unsaturated Flow}

Just as in aquifers, vadose zone water flows from areas of high potential energy to areas of low potential energy. The change in potential energy with direction in space determines the magnitude of the driving force acting on the fluid. Mathematically, the total water potential is expressed as

$\Psi_{T}=\Psi_{f}+\Psi_{g}$

where $\Psi_{\mathrm{f}}$ is the fluid potential $(\mathrm{Pa})$ and $\Psi_{\mathrm{g}}$ is the gravitational potential $(\mathrm{Pa})$. Fluid potential includes capillary (matric) potential $\left(\Psi_{\mathrm{m}}\right)$, hydraulic potential $\left(\Psi_{\mathrm{h}}\right)$, chemical potential, temperature potential, and electrical potential. When considering the movement of water in the vadose zone, chemical, temperature, and electrical potentials are often considered negligible, thus total potential is typically determined from measurements of matric potential under unsaturated conditions, hydraulic potential under saturated conditions, and gravitational potential under both unsaturated and saturated conditions (Stephens 1995). Since the density of water $\left(\rho_{\mathrm{w}}\right)$ and the gravitational constant $(\mathrm{g})$ are considered to remain constant in the vadose zone, total potential is often converted to units of length by dividing pressure units ( $\left.\rho_{\mathrm{w}} \mathrm{gh}\right)$ by $\rho_{\mathrm{w}} \mathrm{g}$, describing total water potential as total hydraulic head $(\mathrm{H})$

$$
H_{T}=h_{w}+h_{g}
$$

where $h_{w}$ is the pore water potential head, which is negative under unsaturated conditions and positive under saturated conditions. Gravitational potential head (or elevation head), $h_{g}$, is typically represented relative to an arbitrary reference head, such as the elevation of the ground water table, mean sea level, or ground surface.

Unsaturated water transport is typically described using Richard's Equation:

$$
\frac{\partial \theta}{\partial t}=\nabla \cdot K(H) \nabla H
$$

\footnotetext{
${ }^{\mathrm{b}}$ Written communication from D. E. Champion (US Geological Survey, Menlo Park, California) to S. L. Ansley (Idaho National Engineering and Environmental Laboratory), May 2003.
} 
where $K(H)$ is unsaturated hydraulic conductivity as a function of hydraulic head and $\nabla$ represents directional gradients. Because Richard's Equation is non-linear and difficult to solve by analytical means, numerical models are often used to solve Equation (3) to describe water transport in the vadose zone. In many instances, the motivation for vadose zone characterization is to provide quantitative information and parameters required by these numerical models. The model parameters include saturated hydraulic conductivity, unsaturated hydraulic conductivity as a function of matric potential, hydraulic gradient, and porosity. While hydraulic head measurements in the vadose zone are readily obtained in situ, field measurements of unsaturated hydraulic conductivity are cumbersome and often associated with a high degree of uncertainty. Thus, parameter estimation models such as the Mualem Model (Mualem 1976) are often employed to estimate $K(H)$ from moisture retention curve fitting parameters (Van Genuchten, et al. 1991) and measurements of saturated hydraulic conductivity. Pedotransfer function models (Haverkamp and Parlange 1986; Arya et al. 1999), often used by researchers to predict hydraulic properties from physical properties of a porous medium, require measurements of dry bulk density and sediment particle-size distribution. Laboratory techniques are typically used to measure hydrological parameters required by these models due to ease of measurement, environmental controls, and a higher degree of precision compared to field techniques.

\subsubsection{Laboratory Measurements}

To obtain hydrological parameters necessary for unsaturated transport modeling beneath the percolation ponds, sections of core were collected from the VZRP during borehole instrumentation and sent to the U.S. Geological Survey Unsaturated-Zone Flow (UZF) laboratory in Menlo Park, California for parameter quantification. The UZF laboratory received ten 0.3 to $0.6-\mathrm{m}$ sections of sedimentary interbed material from seven boreholes, at depths ranging from 37 to $55-\mathrm{m}$ bls. Basalt and shallow alluvium core sections were not analyzed as part of this characterization. Macropore fracture networks dominate fluid transport through basalt, reducing the importance of hydrological characterization of basalt core. Core sections of near-surface alluvium were poorly consolidated and highly disturbed, making characterization difficult. Detailed characterization methods are described in Winfield (2003).

\subsection{Hydrology Data Collection and Management}

Instrument response to infiltration was recorded using advanced tensiometers, water capacitance probes, ERT electrodes, and water level sensors in vadose zone monitoring wells. Water level sensors require a minimum depth of standing water in the wells, resulting in a delayed response and, therefore, are not ideal for monitoring first water arrival times. Water content sensors and ERT arrays are not as extensive throughout the VZRP as the advanced tensiometer packages, and therefore the data cannot be used to monitor water arrival as comprehensively as the tensiometer data. The advanced tensiometers respond very rapidly to minor changes in matric and hydraulic potentials (negative and positive pressures, respectively) and are not sensitive to minor changes in pore water chemistry, reminiscent of the water content sensors and ERT arrays. Therefore, tensiometer data were selected to represent water arrival associated with discharge events discussed in this report. Matric potential, moisture content, subsurface ambient temperature, perched water pressures, and electrical conductivity measurements are recorded on CR23X data loggers located at each instrumented borehole station. Data collected every 15 minutes are averaged using a 9-point running average. The running average is recorded every 4 hours for each instrument, with exception of data logger station 212. Measurements recorded at this station are collected every 15 minutes (unaveraged), because the majority of the measurements are used for monitoring very rapid changes in chemical tracer transport. A narrow-band very-high-frequency telemetry radio system (Campbell Scientific, Logan, Utah) is used to transmit the data every 6 hours to a base-station computer located at the Central Facilities Area of the INEEL. The data are transferred every 3 to 4 days to a database (Microsoft Access) for long-term storage and data management. 


\subsection{Subsurface Visualization}

The Environmental Visualization System (EVS) (CTECH Development Corporation, Huntington Beach, California) was used to construct 2-D cross-sections and fence diagrams of the VZRP subsurface. The visualization system can display multiple layers of information simultaneously with correlation interpolations between data points and wells. The EVS interpolates between data points using a unique three-dimensional kriging model developed specifically for $3 \mathrm{D}$ visualization. The krigged volume is based on a semivariogram created in three-dimensional space resulting in a semivariogram cloud. The model is driven by an expert system that analyzes the input sample pairs to determine the sill, range, reach, lattice size, and cell size. Given a limited set of geohydrological information for a particular random field, the semivariogram created by the expert system is the best choice for parameter interpolations. Model input data for the VZRP cross-sections included lithology, paleomagnetics, electromagnetic resistivity, water temperature, and pore water pressure. For the VZRP images, the measure of error was set at the $80 \%$ confidence level to allow some freedom, yet spatial limitation, during the kriging process. Specific kriging parameters assigned for the VZRP geology representations included the convex hull grid option and a minimum layer thickness of 0.5 , so that the system would pinch out layers in a similar manner to what was actually observed in the paleomagnetic data set. Additional adjustments to the degree of resolution, as well as modifications to the vertical-to-horizontal anisotropy ratio helped obtain the best possible representations and correlations of the spatial relationship of geologic layers.

\section{RESULTS}

Vadose zone lithology, hydrological characterization of interbed sediments, and hydrological data subsurface monitoring of INTEC wastewater infiltration are presented in this section. Three-dimensional subsurface lithology of the vadose zone beneath the VZRP is represented in a cross-well correlation diagram and a 2-dimensional (2-D) EVS diagram showing interpolated lithology between monitoring wells. Laboratory-measured values for saturated hydraulic conductivity and porosity are presented for three major interbeds, denoted as the B-BC interbed (20 to 35-m bls), the C-D interbed (40 to $45-\mathrm{m}$ bls), and the DE-1-2 interbed (55 to $65-\mathrm{m}$ bls), along with an overall physical description of the sediments and geologic depositional environments. Preinfiltration pore water pressure conditions are presented to show the presence and location of preexisting perched water zones before pond discharge. Subsurface infiltration conditions during preliminary pump test discharge and initial high-volume discharge are presented to show water arrival times and arrival sequences. Static conditions are then presented to show formation and locations of perched water zones and recharge locations after several months of discharge to the pond.

\subsection{Geology}

\subsubsection{Description of Vadose Zone Research Park Site-Specific Stratigraphy and Lithology}

The U.S. Geological Survey, Menlo Park, California identified 41 lava flows separated by eolian and alluvial sedimentary interbeds from analysis of core collected from geophysics well 213, and boreholes 214 and 215. ${ }^{\circ}$ These flows were then grouped into nine distinct basalt eruptive events based on paleomagnetic inclination measurements (Figure 13). Basalt flows associated with these events range in thickness from 2.7-m to greater than 60-m and are usually composed of one or more inter-fingering flow units. Basalt flow units are typically 1.5 to $6-\mathrm{m}$ thick. Thin basalt flow units are characteristic of vent-

\footnotetext{
${ }^{\mathrm{c}}$ Written communication from D. E. Champion to S. L. Ansley, May 2003.
} 
proximal eruptions, while units 9-m thick or more are most likely a ponded basalt flow accumulated in a closed topographic depression. Most of the basalt flows do not have significant amounts of cinder, breccia, or rubble at or near their uppermost surfaces, suggesting that most of the basalt flows are pahoehoe or smooth-surface flows. Most basalt and sedimentary units across the VZRP can be subhorizontally correlated. Deeper units exhibit a north to south dip, probably representing subsidence along the axis of the Snake River Plain with lesser rates along the margins (Champion et al. 2002). The uppermost easily correlated unit beneath the VZRP is the C-D interbed, located between 40 and $45-\mathrm{m}$ bls, increasing in depth from north to south. A deeper unifying interbed (DE-1-2) exists between 55 and 65 $\mathrm{m}$ bls. Two well-defined basalt flows occur between these interbeds. The uppermost flow (C basalt flow) is characterized by steep magnet inclinations. The lower basalt flow ( $\mathrm{D}$ basalt Flow) exhibits high gamma signals in borehole geophysical logs, which is associated with the high $\mathrm{K}_{2} \mathrm{O}$ basalt flow of Reed and others (Reed et al. 1997). Beneath the DE-1-2 interbed, basalt flow units provide clear correlation through the entire line of section with the strongest correlations provided by basalt flow tops at depths of 91, 95, and 104-m bls.

The 2-D lithologic cross-section created using EVS represented as a north-south slice through the center of the ponds (viewed from the east) also shows the continuous and discontinuous nature of the interbeds and basalt units across the area, the apparent inter-fingering of basalt flows, and the topographic variability typical of basalt flow surfaces (Figure 14). This slice shows that most of the interbeds are laterally continuous; however, the B-BC interbed pinches out to the north toward the Big Lost River channel. Another interbed at approximately $20-\mathrm{m}$ bls identified near the river pinches out to the south somewhere between well 214 and the southern boundary of the pond. The basalt unit between this interbed and the shallow alluvium pinches out in a similar fashion.

\subsection{Laboratory Measured Interbed Properties}

\subsubsection{Physical Properties}

Laboratory characterization of core samples also identified three major interbeds identified at approximately 20, 40, and 55 meters bls, denoted as the B-BC, C-D, and the DE-1-2 interbeds, respectively. Baked zones were identified in core samples from wells 189 and 213 in the B-BC interbed, well 215 in the C-D interbed, and wells 214 and 215 in the DE-1-2 interbed. The cores examined at the UZF laboratory indicate that the B-BC interbed ranges in thickness from 0.6 to $8.5-\mathrm{m}$, pinching out toward the north end of the pond, then reappearing near the river. The B-BC interbed was present in all 25 boreholes drilled to this depth or deeper. The C-D interbed ranges from 0.6 to $10-\mathrm{m}$ in thickness and is present in 7 of the 18 holes drilled to this depth. The DE-1-2 interbed ranges in thickness from 0.3 to $14-\mathrm{m}$ and is encountered in 9 of the 10 boreholes drilled to this depth. The B-BC interbed is laterally extensive to at least 900-m within the VZRP between the Big Lost River and the new percolation pond

area. Because most of the boreholes were drilled to DE-1-2 or less, it is difficult to make inferences about the lateral continuity of the C-D and DE-1-2 interbeds.

General textural class for the interbed material analyzed from all holes and depths in this study was silt loam. The mean particle size for all interbed intervals ranges from 0.0034 to $0.1992 \mathrm{~mm}$. The mean particle size for the baked zone sediments did not differ significantly from the means of the underlying non-baked intervals. The B-BC interbed is vertically more uniform and is finer than the other two interbeds. The fine texture of this interbed suggests a low-energy depositional environment, possibly of floodplain or lacustrine origin. The mean grain size in the $\mathrm{B}-\mathrm{BC}$ interbed ranged from 0.0034 to $0.0160 \mathrm{~mm}$. The C-D interbed coarsens upward both locally and over a distance of $200-\mathrm{m}$, suggesting a low-energy fluvial system followed by a higher energy system. The greatest spread in particle size was near the top of the C-D interbed, with mean grain sizes ranging from 0.0038 to $0.1715 \mathrm{~mm}$. The DE- $1-2$ interbed shows the most textural variation, with the mean diameter ranging from 0.0081 to $0.1992 \mathrm{~mm}$. 
No clear gradation trends were observed in the DE-1-2 interbed, indicating a more prominent depositional layering within this interbed, possibly from a braided fluvial environment. Mineralogy of interbed sediments in the vicinity are similar to the modern Big Lost River deposits (Perkins 2003), suggesting that the silt-rich interbeds underlying the VZRP may be flood plain deposits of a river containing sediment similar to the current Big Lost River deposits.

\subsubsection{Hydrological Properties}

In general, the laboratory measurements of saturated hydraulic conductivity $\left(\mathrm{K}_{\mathrm{sat}}\right)$ followed the same trend as the particle size data for the interbed sediments examined by the U.S. Geological Survey UZF Laboratory. The range of $\mathrm{K}_{\text {sat }}$ values for the three major interbeds were from $1.66 \times 10^{-7} \mathrm{~cm} \mathrm{~s}^{-1}$ to $1.42 \times 10^{-3} \mathrm{~cm} \mathrm{~s}^{-1}$. The B-BC interbed samples had $\mathrm{K}_{\text {sat }}$ values in the low to middle range of the spectrum with a mean $\mathrm{K}_{\text {sat }}$ value of $1.53 \times 10^{-6} \mathrm{~cm} \mathrm{~s}^{-1}$. Mean porosity of the B-BC interbed was 0.468 . Measured $\mathrm{K}_{\text {sat }}$ values for the C-D interbed decreased with depth, consistent with the downward fining of particle sizes, with a mean hydraulic conductivity of $6.67 \times 10^{-5} \mathrm{~cm} \mathrm{~s}^{-1}$ and a mean porosity of 0.496 . For the DE1-2 interbed, $\mathrm{K}_{\text {sat }}$ generally increased with depth. The mean hydraulic conductivity for the DE-1-2 interbed was $3.64 \times 10^{-4} \mathrm{~cm} \mathrm{~s}^{-1}$ with a mean porosity of 0.514 . Although aggregation was observed in well 215 baked zone sediments, a comparison between hydraulic property data for the baked zone and the non-baked zoned sediments examined is this study showed only subtle differences (Winfield 2003).

\subsection{Hydrology}

\subsubsection{Preinfiltration Subsurface Conditions}

Initial laboratory moisture content measurements of cores at the UZF laboratory indicate that interbed deposits were relatively dry $(<20 \%$ volumetric moisture content). An exception is core collected from the C-D interbed in wells 213 and 214. Volumetric moisture content from core collected from these wells was 40 and $51 \%$, respectively. Field measurements collected before discharge support these findings, showing unsaturated conditions at depths ranging from 13 to $147-\mathrm{m}$ bls. An exception was the C-D interbed, which showed saturated conditions in wells 204 and 198, and basalt at approximately the same depths (45 to 50-m bls) in 214, 195, and 189. Saturated conditions were also observed in well 215 at a depth of 87-m bls (Figure 15).

\subsubsection{Initial Pump Tests}

While testing pump performance, approximately $10,000 \mathrm{~m}^{3}$ of water was discharged to the pond (primarily in the south cell; Figure 6) over a 10-day period from June 18 through June 27, 2002. Tensiometer data collected for well 207 (directly south of the pond) during these initial pump tests show rapid response to recharge at the C-D interbed (Figure 16, 207-41m-I) and at overlying basalt interface (Figure 16, 207-39m-I) about the first of July 2002. Ponding occurred at the interface, reaching nearly a meter of saturated pore water until testing was completed. The saturated water above the interface began to drain rapidly once discharge ceased; however, recharge to the C-D interbed continued as the overlying column of water drained, taking several months to drain. Slow infiltration was observed at the underlying basalt interface (Figure 16, 207-41m-B) about the end of July 2002, leveling off at 0-cm pressure head in early August 2002. None of the other tensiometers in this well (located at 19, 20, 28, and 37-m bls) or at any other well in the proximity of the pond responded to water arrival from this event.

\subsubsection{Infiltration Conditions}

High-volume discharge ( $\left.>4000 \mathrm{~m}^{3} \mathrm{day}^{-1}\right)$ to the south cell began August 27, 2002 and continued through September 20, 2002 (Figure 6). Discharge was switched from the south cell to the north cell on September 21, 2002, then switched back to the south cell October 5, 2002. During this time period, tensiometer data, water content sensor data, and water level data show rapid response to infiltration and 
changes in discharge locations. Moisture sensor measurements are presented to validate the reliability of advanced tensiometer data for representing initial water arrival. Water level measurements from vadose zone monitoring wells are presented to validate the reliability of advanced tensiometers for monitoring positive hydraulic head in the vadose zone.

\subsubsection{Tensiometer Measurements}

All tensiometer data presented in this section represent daily averages. Although barometric data are available, the tensiometer data presented in this documents have not yet been corrected for the effects of barometric pressure. Extreme fluctuations in pressure head during initial water arrival (August through October) reflect sensitivity to discharge location and flux, while fluctuations in hydraulic pressure after the end of October 2002 reflect either significant changes in discharge volume or times when transducers were pulled for calibration. Sensor depths below land surface are based on geologic logs collected during drilling and sensor installation. Table 2 lists tensiometer depths below land surface, lateral distances from the pond (relative to well 212 at the center berm), and estimated flow rates. The flow rates were calculated assuming a lateral principal flow direction from the pond.

Tensiometer data from instrumented boreholes around the perimeter of the ponds show rapid response to infiltration once high-volume discharge began to the pond in August 2002. Unfortunately, the data logger battery at station 207 failed during the month of September and data were not recorded for well 207 until October 2002. Tensiometers in wells 204, 205, and 215 began responding to water infiltration at the end of August 2002. Most of the shallow tensiometers in wells 204 and 205 responded very quickly to initial infiltration and changes in discharge location that occurred from August 27 through October 4, 2002 (Figure 17 and Figure 18). A delayed rapid response to infiltration was observed in well 198 (Figure 19), also showing response to changes in discharge location. Tensiometers in well 215 show rapid infiltration near the C-D interbed and slow infiltration near the DE-1-2 interbed (Figure 20). The only sensors that appeared to respond to changes in discharge location in well 215 are located near the interface of the C-D interbed (Figure 20, 215-43m-B and 215-45m-I).

\subsection{Well 204}

Well 204 is instrumented with ten advanced tensiometers to a depth of 51-m bls. The well is located approximately 120-m northwest of the center berm of the pond (Figure 7). Shortly after high volume discharge began to the south pond August 27, 2002, rapid infiltration was observed at the alluvium / basalt interface 14-m bls (Table 2), eventually reaching a peak thickness of nearly $50 \mathrm{~cm}$ of saturated pore water in the region above the interface (Figure 17, 204-14m-A). The saturated pore water quickly drained once the water was diverted to the north cell of the pond September 21, 2002. The alluvium re-saturated once the north cell water reached the interface, eventually reaching nearly $2-\mathrm{m}$ in thickness. After switching discharge back to the south cell October 5, 2002, the alluvium quickly drained again and remained unsaturated, never returning to the saturated thickness observed during initial infiltration to the south cell.

The tensiometer located in the middle of the shallowest basalt layer at 18-m bls (Figure 17, 204-18m-B) reached a peak of 3-m saturated pore water during initial infiltration to the south cell. This saturated zone quickly drained almost 1-m when discharge was switched to the north cell. The region resaturated and reached a peak of more than 4-m during north cell discharge. Once water was routed back to the south cell, the basalt drained and stabilized near 2-m pore water pressure, slightly lower than observed during initial infiltration to the south cell.

Response to infiltration within the B-BC interbed at 19-m bls (Figure 17, 204-19m-I) was similar to observations in the overlying basalt; however, the saturated region was not as thick. Rapid infiltration was observed in a thin interbed located at 27-m bls (Figure 17, 204-27m-I), stabilizing at about 30-cm 
pore water pressure within only a few days after first water arrival. The tensiometer at this location did not appear to respond to changes in discharge location.

Slow infiltration was observed at 31-m bls Figure 17, 204-31m-B), near the top of a 20-m-thick basalt unit. Pore water pressure at this depth reached a stable value in December 2002, only slightly above saturation $(0 \mathrm{~cm})$. Alternatively, rapid infiltration was observed in this thick basalt unit at 39 and 45-m bls (Figure 17, 204-39m-B and 204-45m-B). The tensiometer at 39-m bls responded slightly to changes in discharge location and reached a peak of about $5-\mathrm{m}$ pore water pressure during discharge to the north cell. The pressure stabilized near 4-m pressure after switching discharge back to the south cell, similar to the pressure reached during initial infiltration to the south cell of the pond. Pore water pressure rose to as high as 9-m at the 45-m tensiometer; however, response to changes in discharge location was not observed at this depth. Similar behavior was observed in the C-D interbed at 46-m bls (Figure 17, 204-46m-I), with pore water pressure also reaching nearly 9-m and no apparent response to changes in discharge location. Alternatively, the tensiometer at 48-m bls in the C-D interbed (Figure 17, 204-48m-I) only reached a peak of $5-\mathrm{m}$ pore water pressure during initial infiltration. This may reflect instrument malfunction, however, since the upper limit for transducer operation is approximately 8-m positive pressure. Excessive scatter in the data for this sensor supports this premise, suggesting the data for this sensor is questionable. The tensiometer at 51-m bls (Figure 17, 204-51m-B), also located in a thick basalt unit, showed slow infiltration with slight response to changes in discharge location. Recharge to this basalt unit appeared to increase sharply about the end of October 2002.

\subsection{Well 205}

Well 205 is instrumented with ten advanced tensiometers to a depth of $45-\mathrm{m}$ bls. It is located approximately $120-\mathrm{m}$ north of the center berm of the pond near the edge of the north cell (Figure 7). Similar behavior was observed in well 205, with tensiometers showing rapid infiltration at the alluvium/ basalt interface (Figure 18, 205-15.5m-A), the underlying basalt (Figure 18, 205-16.5m-B), the B-BC interbed (Figure 18, 205-17m-I), and in the center of a thick basalt layer at 29 and 32-m bls (Figure 18, 205-29m-B and 205-32m-B). Rapid infiltration and high pore water pressures were also observed in the C-D interbed (Figure 18, 205-39m-I, and 205-40m-I) and at the overlying basalt interface (Figure 18, 205-38m-B); however the saturated region at this location was not as thick as the perched zone observed in well 204 at the same depth (6-m thick compared to 9-m observed in well 204). Pore water pressures stabilized after switching discharge back to the south cell in October, 2002 at lower pressures than observed during initial infiltration for the shallow sensors (Figure 18, 205-15.5m-A, 205-16.5m-B, and 205-17m-I) and slightly lower at 29-m bls (Figure 18, 205-29m-B). Responses to infiltration in the C-D interbed and at the overlying basalt interface were much sharper than responses observed in well 204 at similar depths.

\subsection{Well 198}

Well 198 is instrumented with nine advanced tensiometers to a depth of $47-\mathrm{m}$ bls. It is located approximately 215-m north of the center berm of the pond (Figure 7). A delayed rapid response to infiltration was observed in well 198 for tensiometers located at 37 and 38-m bls in the C-D interbed (Figure 19, 198-37m-I and 198-38m-I), showing water arrival about 2 weeks after initial discharge began to the south cell. Both tensiometers showed sensitivity to changes in discharge location, stabilizing at pore water pressures about 3 to $4-\mathrm{m}$ after the final switch back to the south cell. The stabilized pressures were about one $\mathrm{m}$ higher than the pressures observed during initial infiltration. Slower infiltration was observed at 32, 33, 34, and 43-m bls in both interbed and basalt layers (Figure 19, 198-32m-B, 198-33mI, 198-34m-B, and 198-43m-I, respectively). Tensiometer responses to changes in discharge were not as distinct for these sensors relative to the C-D interbed sensors. Pore water pressure at the alluvium basalt interface (Figure 19, 198-16m-A) only increased slightly, and water did not arrive at this depth until much 
later than the other sensors (mid-October 2002). Water arrival was never observed at the $21-\mathrm{m}$ depth sensor (Figure 19, 198-21m-B) located in the middle of a thick basalt layer (roughly 30-m thick).

\subsection{Well 215}

Well 215 is instrumented with seven tensiometers to a total depth of 147-m bls (Figure 20). It is located approximately 138-m from the center berm of the pond (Figure 7). Rapid infiltration was observed at the alluvium/basalt interface (Figure 20,215-24m-B) about the end of August 2002, shortly after discharge began to the south cell; however, the pore water pressure only increased $10-20 \mathrm{~cm}$. The pressure at this interface began to drop somewhat after about a week, leveling off at about $0 \mathrm{~cm}$ at the end of September 2002. Rapid infiltration was observed at 43 and $45-\mathrm{m}$ bls near the interface of a thick basalt layer (Figure 20, 215-43m-B) and the C-D interbed (Figure 20, 215-45m-I). The pressure in both of these tensiometers leveled off at about 6-m positive pressure around mid-September 2002. At the end of September, the 43-m sensor rose sharply to nearly 8-m pressure, while the 45-m sensor dropped sharply to only 2-m pressure. Both the 58-m sensor in the DE-1-2 interbed (Figure 20, 215-58m-I) and the 87-m sensor in basalt (Figure 20, 215-87m-B) showed slow infiltration, with no apparent response to changes in discharge location. Water arrival was never observed in the deep sensors at 102 and $147-\mathrm{m}$ bls (Figure 20, 215-102m-B and 215-147m-B).

\subsection{Well 189}

Well 189 is instrumented with seven tensiomters to a total depth of $45-\mathrm{m}$ bls. It is located approximately 860-m north of the center berm of the percolation pond, on the north side of the Lost River (Figure 7). Slow infiltration was observed in well 189 at 31-m bls beginning in early September 2002. Pore water pressure head increased slowly over several months, reaching a relatively steady state condition near 70-cm positive pressure about March 2003 (Figure 21). Infiltration has not been observed in this well at any other depth.

\subsection{Wells 192, 214, and 195}

Although perched water was observed in both wells 195 and 214, both located approximately 400-m north of pond midway between the Big Lost River and the ponds, before discharge to the VZRP percolation pond (Figure 15), infiltration was not observed at any depths in these two wells. However, three of the eight tensiometers in well 195 (at 24, 33, and 41-m bls) were determined to be inoperable during calibration in October 2002; therefore, data collected at these depths during initial high volume discharge to the pond are not reliable. Water arrival has not been observed at any of the sensor depths in well 192, located south of Big Lost River, approximately 821-m north of the pond; however, there are no monitoring instruments located between 23 and $34-\mathrm{m}$ bls where perched water may be present.

\subsubsection{Water Content Sensors}

Although the water content (WC) absolute values are somewhat suspect due to possible installation problems, the sensor data can be used to validate the accuracy of the water arrival times determined from tensiometer data (AT). The water content sensors are highly sensitive to changes in dielectric constant and respond rapidly to water infiltration, particularly in initially unsaturated porous media. Water content and tensiometer data collected for sensors located in wells 198, 204, and 205 at similar depths within the C-D interbed are shown in Figure 22 through Figure 24. The tensiometer and water content sensors responded at the same time for all three of these wells during initial infiltration. Note that water arrival in the C-D interbed at well 198, 215-m away from the pond, occurred about the same time as arrival to well 204, located only 120-m from the pond. In addition, water arrived at well 205 almost a week earlier than arrival at well 204 in this interbed. Wells 204 and 205 are at the same radial distance from the center berm of the pond. 


\subsubsection{Water Level Measurements}

Water level (WL) measurements recorded in the vadose zone monitoring wells provide information on the formation and longevity of perched water zones, water chemistry, and fluid transport during tracer studies. The submersible pressure transducers installed in vadose zone monitoring wells also support tensiometer measurements of total pressure head, validating the reliability of the advanced tensiometer data for measuring saturated pore water pressures. The water level sensors are not ideal for identifying first water arrival time and hence transport times, because the sensors require buildup of a few $\mathrm{cm}$ of standing water in the well before positive pressure is recorded. The WL sensors can only detect positive pressures, unlike the tensiometers, which were designed to measure pore water suction in porous media. Comparison between water level and tensiometer measurements during initial infiltration shows waterlevel response lagged 1 to 2 days behind AT response under rapid infiltration (Figure 25) and several days behind AT response under slower infiltration (Figure 26); however, the total pressure head values [Equation (2)] are similar for sensors completed at the same depth (Figure 26) and vary by the difference in sensor depth for sensors completed at different depths (Figure 25) (values lie within the degree of uncertainty in depth measurements, which are roughly 0.5 to $0.75-\mathrm{m}$ ).

\subsubsection{Steady-State Conditions}

Figure 27 shows regions of subsurface water saturation below the VZRP percolation ponds after one month of high-volume continuous discharge to the south cell. Nearly all depths are saturated in boreholes adjacent to the pond, with the exception of a few shallow locations and thick basalt layers. Well 198 was saturated from 34 to $43-\mathrm{m}$ bls, even in the basalt layers, but was unsaturated at all locations shallower than 34-m bls. Well 215 was saturated at all sensor locations from 24 to $87-\mathrm{m}$ bls; however, water arrival has not been observed in sensors located in thick basalt at 102 and 147-m bls. The preinfiltration perched zone at $87-\mathrm{m}$ bls southeast of the pond (in well 215) increased gradually in thickness from October 2002 through July 2003 (Figure 20). The perched zone identified north of the pond at approximately 45-m bls (wells 204, 198, 214, 195, 213, and 189) has not increased significantly in thickness, except for regions in close proximity to the pond (204 and 198) and well 189, which has only changed by approximately $50 \mathrm{~cm}$.

Figure 28 shows the formation of new perched zones observed after 6 months of discharge to the percolation pond. New perched water formed at most interbed/basalt interfaces monitored around the perimeter of the pond (extending 200-m laterally to the north and vertically to a depth of 76-m bls). Water level monitoring wells 210 and 211 south of the pond had 4 to 5 meters, respectively, of water pressure after 6 months of continuous discharge to the south cell. Wells 202 and 200 on the north end of the pond had 2 and 5 meters of water pressure, respectively, after 6 months of discharge to the south pond. Well 212 had 4-m of water pressure, and well 197 had 3-m of water pressure after 6 months of discharge. All monitoring locations shown in Figure 28 were unsaturated before high volume continuous discharge began to the new percolation pond.

\section{DISCUSSION}

Hydrological data collected at the VZRP in the first year of wastewater discharge to the percolation pond cells indicate that perched water was present beneath the VZRP in the absence of local recharge, that water infiltration was non-sequential with depth and radial distance from the pond, and that flow paths were highly sensitive to discharge location and surface flux rates. The data show rapid and extensive vertical and lateral water transport within interbed sediments and basalt facies, and temporal changes in hydrologic conditions that do not appear to be related to changes in flux rates or discharge location. A discussion of these observations are included in this section, along with implications for contaminant transport within similar complex vadose zones, and actions needed to investigate these implications. 


\subsection{Preinfiltration Perched Zones}

The perched zone identified at approximately $45-\mathrm{m}$ bls north of the pond before pond discharge began increases in thickness from only a few $\mathrm{cm}$ near the river in a southern direction to the percolation pond where it is nearly a meter thick. The increase toward the pond may relate to the south dipping lithofacies that slopes toward a depression directly beneath the pond (Figure 13). The second perched region, identified southeast of the percolation pond in well 215 within a thick basalt layer at a depth of almost $90-\mathrm{m}$ bls, also had a thickness of 1 meter before discharge began to the pond. No other sensors have been installed at this depth at the VZRP, so the extent of the perched zone cannot be identified at this time. Although the Big Lost River has been identified as a source of local recharge to the C-D interbed (Nimmo et al. 2002), the river is historically intermittent, depending on upstream irrigation in the Big Lost River basin. The last recorded flow in the channel adjacent to the VZRP was in May 2000.

\subsubsection{Implications}

Recharge from the Big Lost River appears to be both laterally and vertically extensive, not only in the C-D interbed, but possibly at even deeper locations. The longevity and thickness of these zones suggest that perched water does not necessarily drain rapidly in complex vadose zones after recharge ceases. The implications for the presence, extent, thickness, and longevity of these perched water zones are that (a) extensive lateral infiltration at interbed/basalt interfaces could lead to large-scale spreading of vadose zone contaminants from sources areas, (b) the longevity of perched water in the absence of recharge could result in unexpected rapid and extensive spreading of contamination in the event of accidental spills or leaks to the subsurface, and (c) large uncertainties may be associated with contaminant transport predictions that assume rapid drainage occurs in the absence of recharge.

\subsubsection{Actions Needed to Investigate Implications}

Actions needed to investigate these implications are (a) in-depth examination of lateral water movement within perched water zones, (b) installation of additional instrumented boreholes and monitoring wells along a transect from the river to monitoring station 195 at the VZRP, (c) installation of deep monitoring wells/instruments to examine water recharge from the river to well 215 at $87-\mathrm{m}$ bls, (d) intense monitoring during flow in the Big Lost River, (e) perched water well tracer injections to monitor flow paths between wells, and (f) installation of additional monitoring wells north of the river to examine the northern extent of recharge toward TRA.

\subsection{Initial Water Arrival}

\subsubsection{Pump Test Results}

Tensiometer response from well 207 to this early discharge while testing wastewater pumps in June 2002 is significant because (a) initial moisture content at well 207 was representative of vadose zone conditions throughout the INEEL under natural recharge, (b) the infiltration rate was within the range of historical infiltration rates observed during flood and snow melt events at the INEEL (Vigil 1998), (c) rapid infiltration was observed at the basalt/C-D interbed interface at approximately $40-\mathrm{m}$ bls within a couple of weeks after initial testing began, (d) slow infiltration was observed at the underlying basalt interface at 44-m bls a month after initial testing, and (e) infiltration was not observed at any other location within this well or other wells around the perimeter of the pond during this test period. These observations suggest a fast pathway exists beneath the pond, directing flow in a vertical direction until reaching the basalt/C-D interbed interface. 


\subsubsection{Implications}

Episodic flood and snowmelt recharge could lead to rapid, deep infiltration through thick basalt layers until reaching interbed sediments. Once reaching the interbed layers, significant perching can occur, leading to extensive, rapid lateral transport. Rapid contaminant transport through interbed sediments could lead to reduced chemical sorption and transport retardation.

\subsubsection{Actions Needed to Investigate Implications}

Additional short-term infiltration tests are required to better understand the magnitude of lateral and vertical infiltration during episodic flood and snowmelt events common at the INEEL. The tests should be conducted under initial and boundary conditions analogous to complex vadose zones at the INEEL under natural recharge.

\subsubsection{Water Arrival Sequences and Travel Times}

Water transport times for each well receiving recharge, calculated from initial arrival and lateral distance from the pond, ranged from 3 to $35-\mathrm{m} \mathrm{day}^{-1}$ (Table 2). Non-sequential vertical transport was observed during initial water arrival to vadose zone sensors in four of the five observation wells that received recharge from the pond during initial infiltration (Figure 29). The only well exhibiting sequential water arrival was well 215 (Figure 30). Non-sequential lateral transport was also observed within similar lithofacies (Figure 31). Water arrived at the alluvium/basalt interface at well 215 (138-m from pond and 24-m bls) a couple days before arriving at wells 204 and 205 (both 120-m from pond and approx 15-m bls). Faster transport to well 215 may be related to the depression under the pond (Figure 13). Water arrived at the C-D interbed in well 198 at approximately the same time as wells 204, 205, and 215; all of which are nearly 100-m closer to the pond than 198. This suggests that a unique flow path may exist from the pond to the C-D interbed in well 198.

Apparent water arrival to well 189 (31-m bls, 860-m from the pond) was observed about the same time as water arrival to wells 198 (37-m bls), 204, and 205 (48 and 40-m bls, respectively) (Figure 21). Because well 189 is greater than $800-\mathrm{m}$ from the pond, instrument malfunction is a concern, particularly since infiltration was observed so soon after high volume discharge to the pond began. Assuming initial water arrival was related to discharge in August 2002, the transport time would be close to $60-\mathrm{m} \mathrm{day}^{-1}$. For this reason, the transducer at this depth was pulled for calibration in October 2002 and temporarily replaced with an alternate transducer for one month until calibration was completed. The observed pressure did not change significantly between the original transducer, the temporary transducer, or the recalibrated transducer. This suggests that the original and alternate transducers were functioning properly. Video logs recorded before well instrumentation show standing water in the borehole at approximately 33-m bls, confirming the presence of perched water at this depth before pond discharge. Recharge to the well at 31-m bls was observed during tracer studies conducted in June 2003, when the pressure transducer assembly was hung above the tensiometer cup in the access tube, allowing water to enter the tube for sample collection. Although tracer analysis has not yet been completed for water samples collected from this well, standing water was observed in the access tube within 1 to 2 days after each sampling purge. This supports the initial water arrival observations, suggesting recharge from the pond is reaching lateral distances as extensive as the Big Lost River, at least within this local region of the subsurface.

\subsubsection{Implications}

Non-sequential water arrival observations suggest that the dominant type of flow in the vadose zone beneath the VZRP is preferential type flow. This type of flow at the VZRP appears to be strongly controlled by contrasts in lithology and the presence of fast pathways in fractured basalts. The high variability in transport times to individual locations suggests complex flow pathways are present in the 
subsurface at the VZRP. This type of flow may be very difficult to predict using traditional numerical models and may not be repeatable.

\subsubsection{Actions Needed to Investigate Implications}

Utilization of a robust numerical model is required to adequately predict variably saturated fluid transport in complex vadose zones. Detailed geohydrological characterization of the subsurface materials and some understanding of the fracture networks and surface textures at basalt flow interfaces would greatly improve model predictions. Although it would be very difficult to quantify subsurface basalt fracture networks at the VZRP, it may be useful to examine fractures, columnar jointing, and surface textures visible in various basalt flows exposed at the surface. Trends in fracture types, distributions, and aperture sizes for different types of basalt flows could be used analogously to develop a more representative geohydrological conceptual model for transport at the VZRP.

\subsubsection{Sensitivity to Discharge Location}

Most shallow sensors less than 40-m bls that received rapid infiltration showed response to changes in discharge locations before October 5, 2002 (Figure 17 through Figure 20). Most of the deep sensors and sensors that received slow infiltration did not show sensitivity to changes in discharge location. The discharge location between the two cells of the pond is only 30 lateral meters apart, indicating that a great deal of spatial variability exists in the hydraulic properties of the shallow subsurface materials. The fact that not all shallow sensors responded to changes in discharge location, even ones that received rapid infiltration (e.g., Figure 17, 204-27m-I), supports the premise that flow pathways, even in the shallow subsurface, are highly complex.

\subsubsection{Implications}

Transport pathways controlled by heterogeneities in the shallow alluvium may be diverting flow in a lateral direction long before reaching the alluvium/basalt interface at approximately $20-\mathrm{m}$ bls. The alluvium has not yet been fully characterized, and sensors have not been installed in the alluvium near the percolation pond. A lack of detailed characterization and hydrologic data of the alluvium deposits may result in large uncertainties in transport predictions at the VZRP.

\subsubsection{Actions Needed to Investigate Implications}

Shallow instrumented boreholes around the perimeter of the pond, and possibly even one or both cells of the pond, are required to better understand transport behavior through the alluvium. Intact core sections collected during well installation could be used for hydrological and physical characterization of the sediments. Pore water sample collection during tracer studies would contribute greatly to our understanding of transport pathways and behavior in the alluvium as a function of discharge location and variable flux rates.

\subsubsection{Transient Hydraulic Condition Observations}

Changes in subsurface hydraulic conditions were observed after pond discharge was redirected back to the south cell October 5, 2002 in some of the instrumented boreholes. The changes were observed several weeks after continuous discharge returned to the south cell; therefore, they do no appear to be connected to changes in discharge location. The changes also do not appear to be associated with decreases in discharge flux rates (Figure 32 through Figure 35). It appears that either fine particles were flushed out of large pores during initial infiltration or fast pathways were encountered over time, decreasing the pore water pressure to values lower than those observed during initial discharge to the south cell. The changes in hydraulic conditions were observed in all facies, though they were prevalent in interbed sediments and alluvium. They were also observed at shallow and deep sensor locations. 


\subsubsection{Implications}

Changes in hydraulic properties over time can seriously complicate vadose zone transport predictions. Particle flushing due to rapid infiltration would result in non-repeatable transport; however, monitoring and identifying transient hydraulic changes would provide insight into how, where, and possibly why fast pathways form or are encountered under rapid infiltration.

\subsubsection{Actions Needed to Investigate Implications}

Again, robust numerical modeling and detailed characterization of the subsurface lithology would greatly improve our ability to understand complex transport behavior at the VZRP. Controlled infiltration tests at various flux rates would assist in isolating the cause of these changes and improve our understanding of how fast pathways influence transport in the vadose zone.

\section{CONCLUSIONS}

Water transport through perched water zones and fast pathways is of particular concern in predicting contaminant transport and long-term stewardship of contaminated vadose zones. Formation of perched water increases hydraulic conductivity, reducing chemical residence time and sorption, consequently increasing the potential for spreading contaminants great distances from source areas. Fracture networks within rock layers are difficult to characterize using traditional methods and are often neglected in transport predictions. Hence, current vadose zone transport models fail to capture the potential for rapid transport through fractured rock. Long-term stewardship requires better understanding of mechanisms contributing to the formation, longevity, and transport within perched water zones and a means to characterize and incorporate fracture networks into vadose zone transport models.

Historically, diffuse-flow conceptual models have been adopted at the INEEL for contaminant transport in the vadose zone, and risk managements decisions have been based on the assumption of diffuse type transport. Recent investigations conducted at the INEEL suggest that water may instead be moving along more preferential flow paths. Hydrological data collected in the first year of discharge at the Vadose Zone Research Park support these findings and show that preferential flow conceptual models are the most appropriate models for describing flow in the vadose zone in this region of the INEEL.

The current monitoring structure at the VZRP is providing researchers with valuable information to better understand the transport complexity in heterogeneous vadose zones. However, additional instrumentation focusing on (a) individual pathways under controlled boundary conditions and (b) the formation, longevity and extent of perched water zones would contribute greatly to improving the conceptual model for contaminant transport in complex vadose zones. 


\section{FIGURES (1-35)}
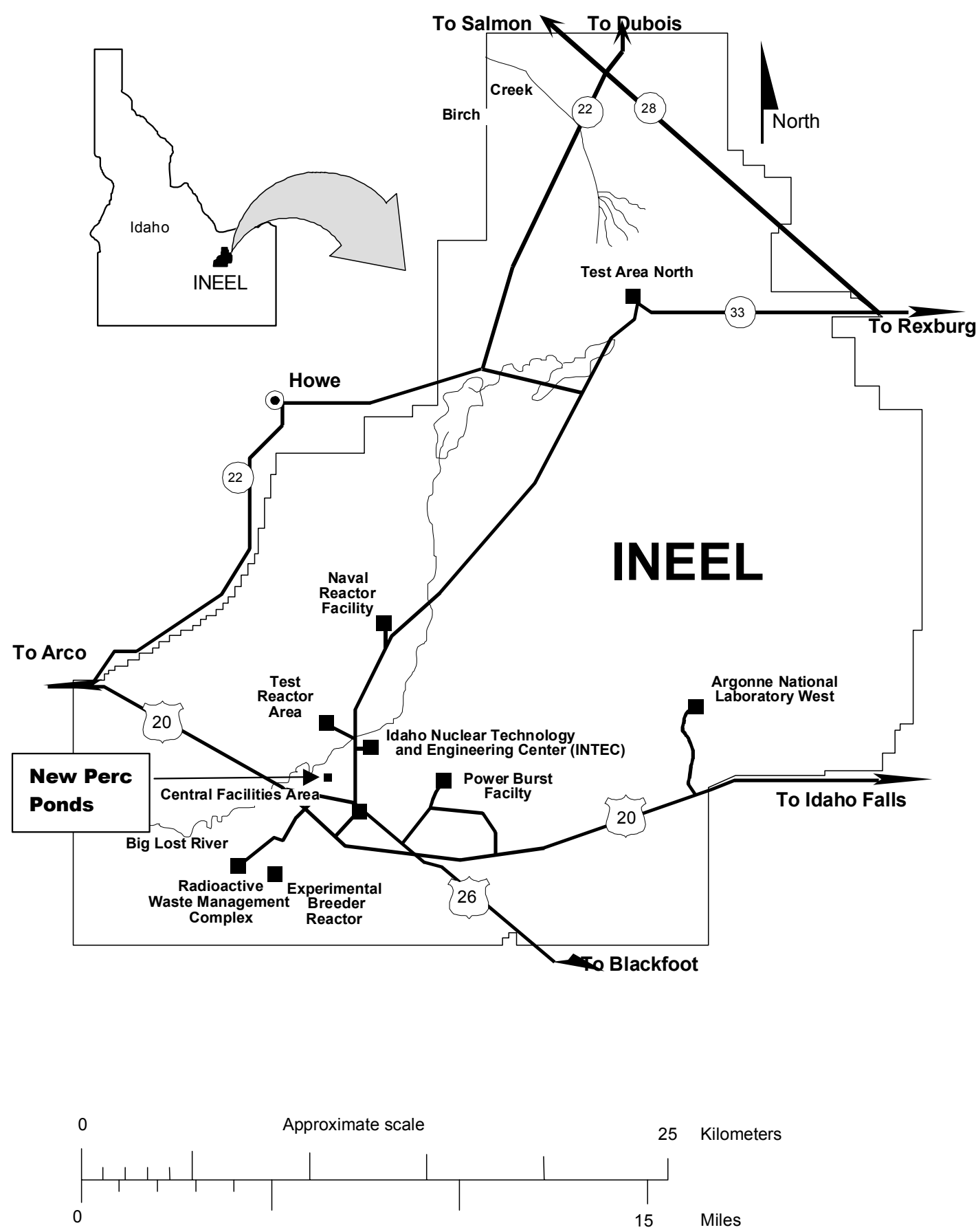

WAG7JB97-004

Figure 1. Map of the INEEL, showing the locations of major facilities and the Vadose Zone Research Park at the new INTEC (Idaho Nuclear Technology and Engineering Center) Perc Pond. 


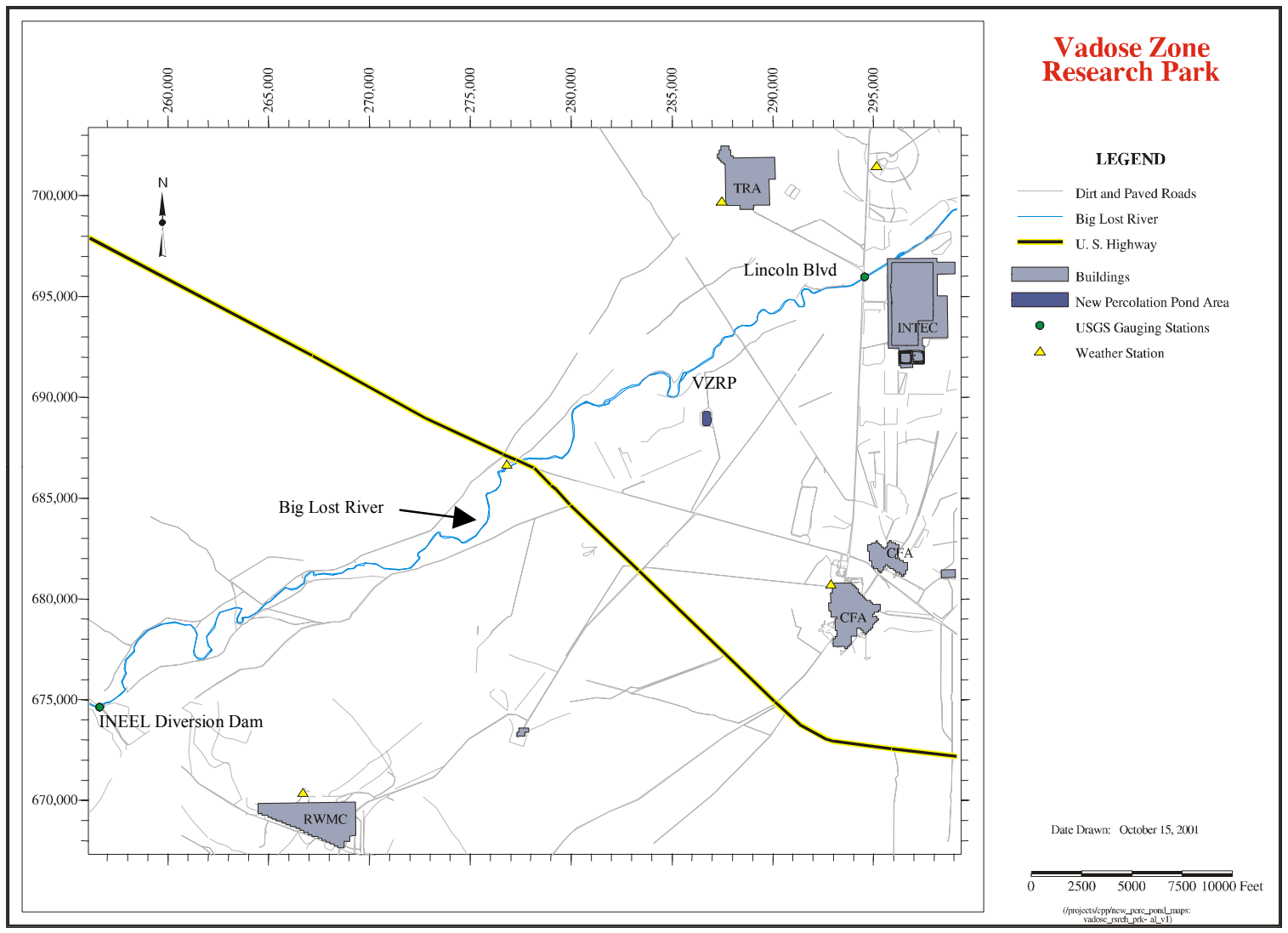

Figure 2. Map of the INEEL, showing the location of facilities, river gauging stations, and weather stations near the vadose zone research park.

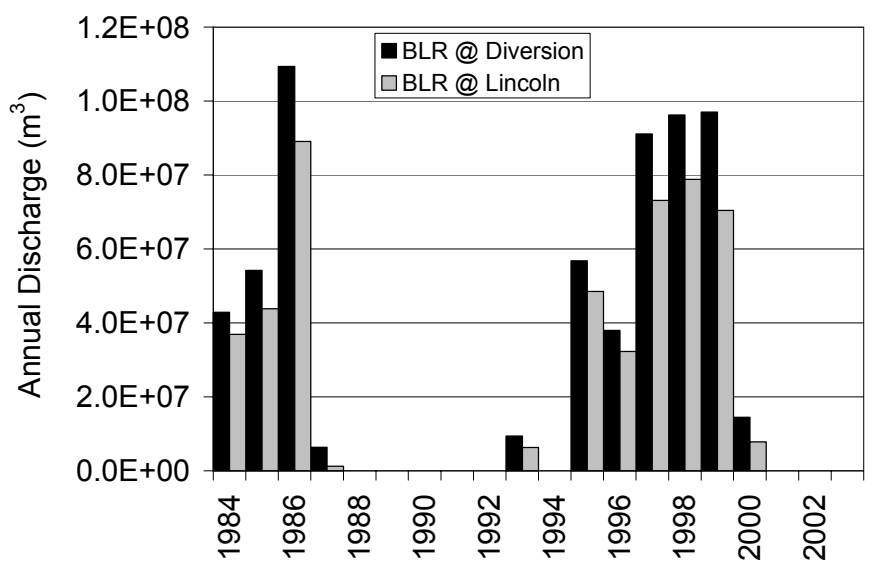

Figure 3. Annual total discharge in the Big Lost River at the INEEL diversion dam, upstream from the Vadose Zone Research Park, and at Lincoln Blvd., downstream from the park. 


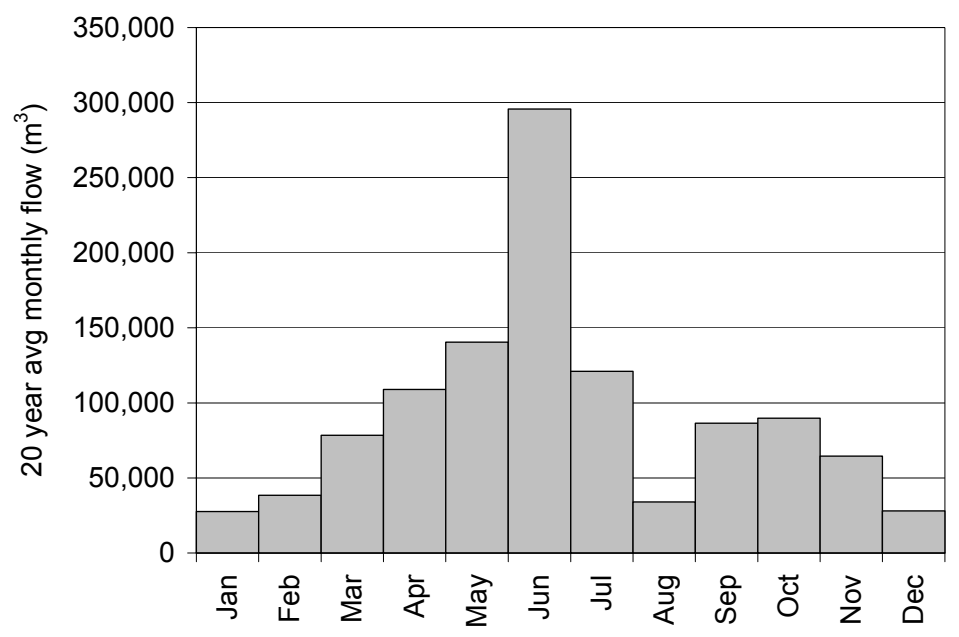

Figure 4. Average monthly discharge at the INEEL diversion dam from July 1984 through September 2001.

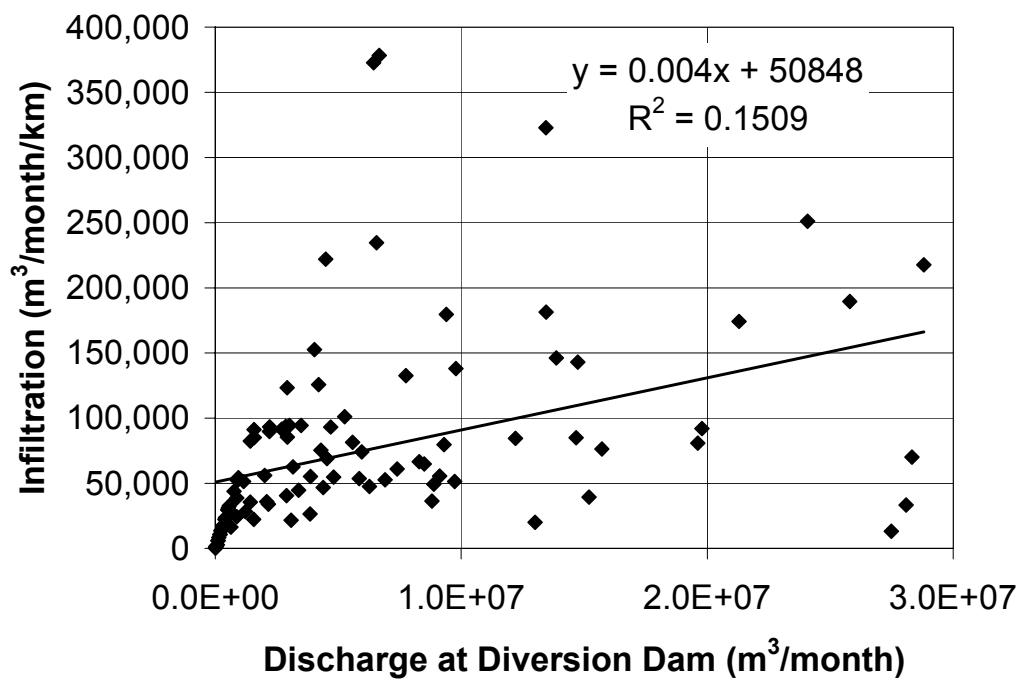

Figure 5. Correlation of infiltration rate with Big Lost River discharge at the INEEL diversion dam. 


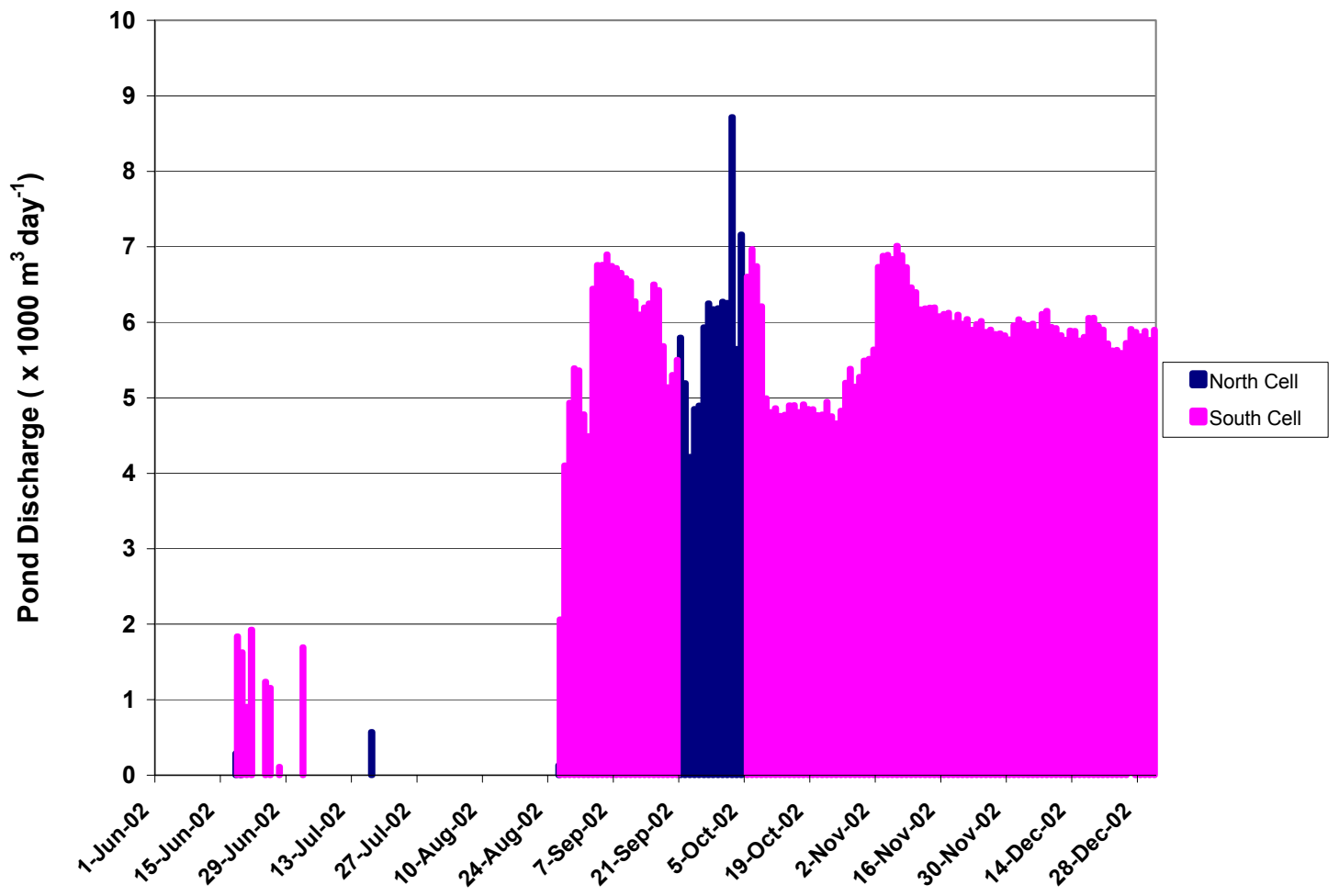

Figure 6. Discharge to north and south cells of the new INTEC percolation pond during initial system testing and initial production use of the pond in the summer of 2002. 


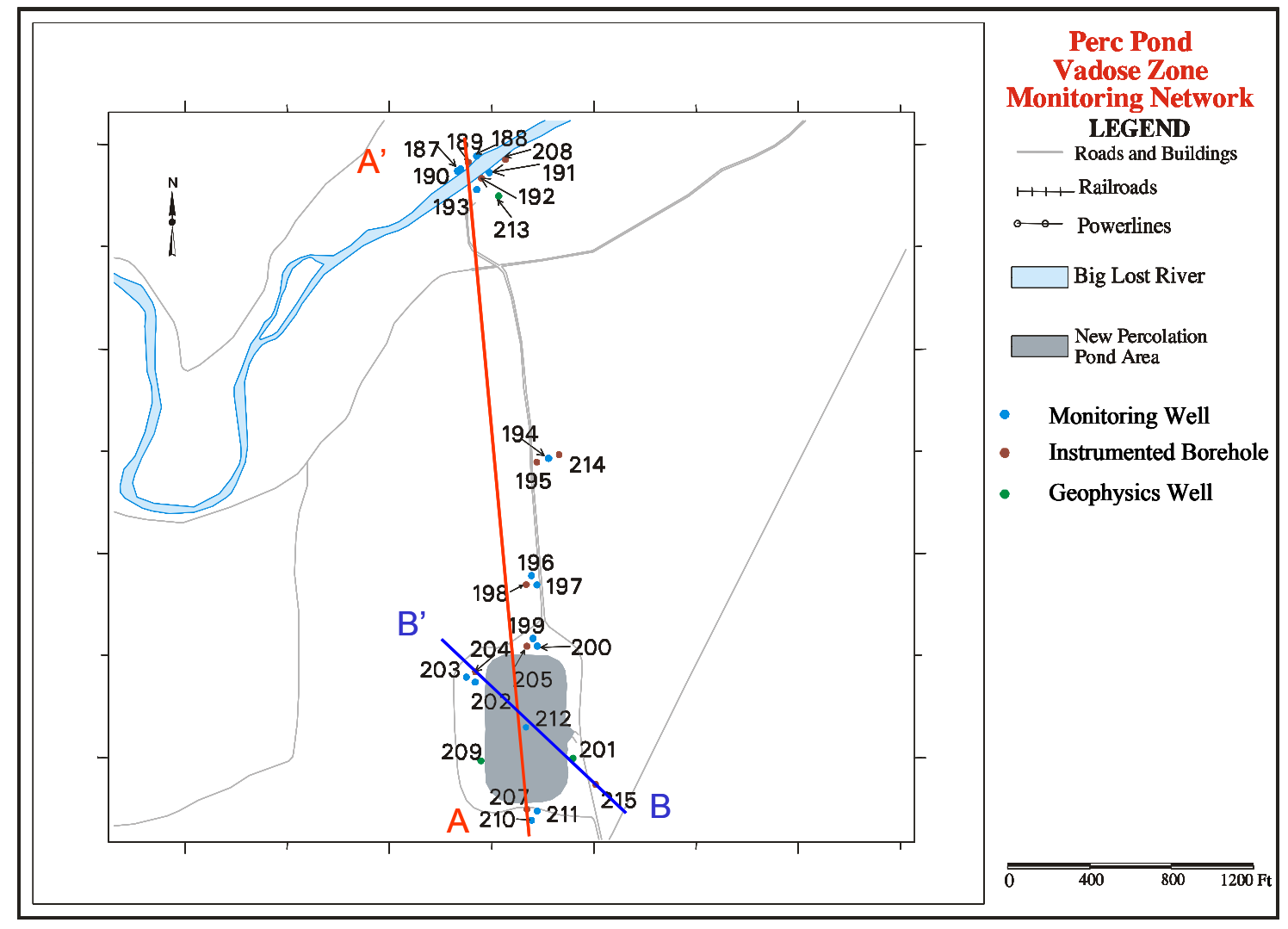

Figure 7. Map of the Vadose Zone Research Park, showing the location of aquifer wells and core holes. Cross-sections A-A' and B-B' are slices through the vadose zone used to visualize subsurface hydrological conditions in Figures 16 and 28.

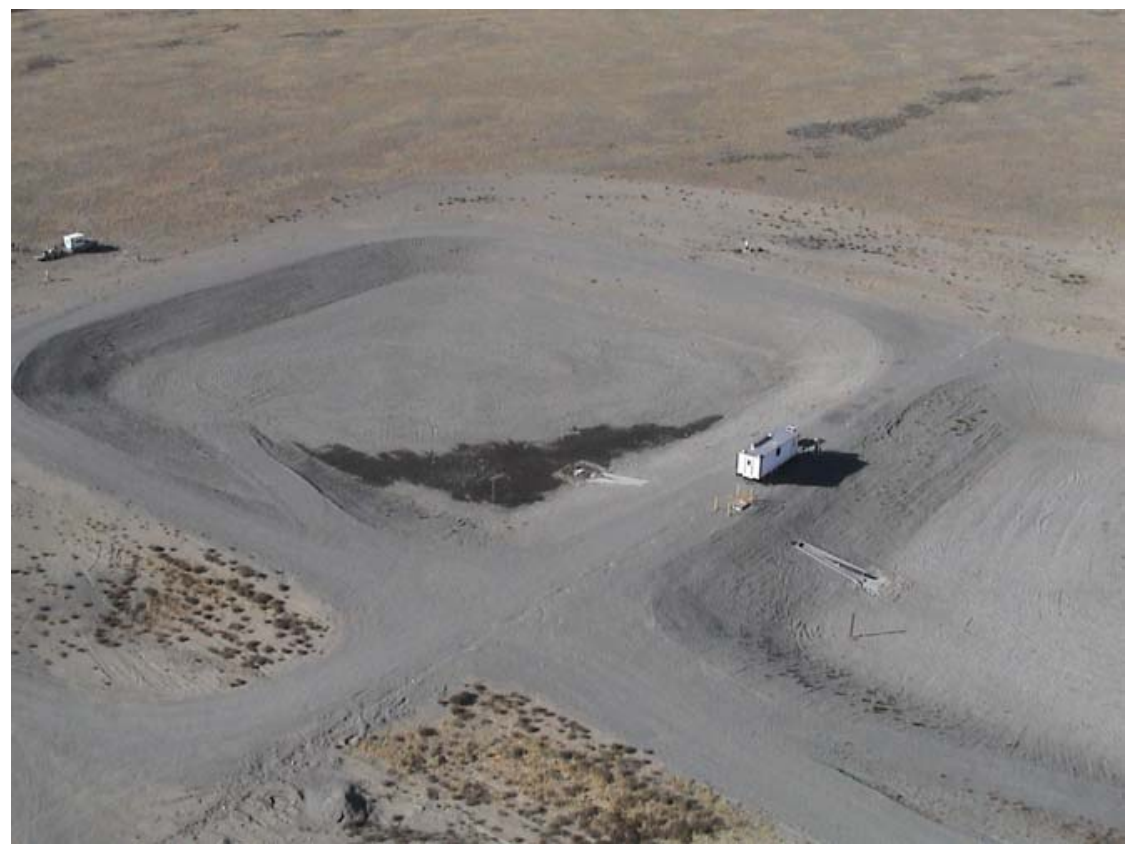

Figure 8 . The new percolation pond, showing the extent of ponding in the south cell. 


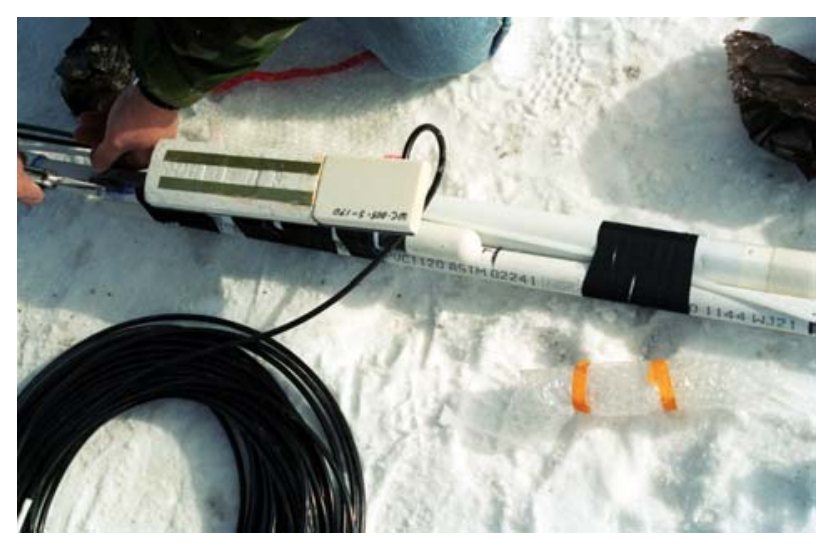

Figure 9. Instrument bundles were assembled on the land surface and inspected before installation.

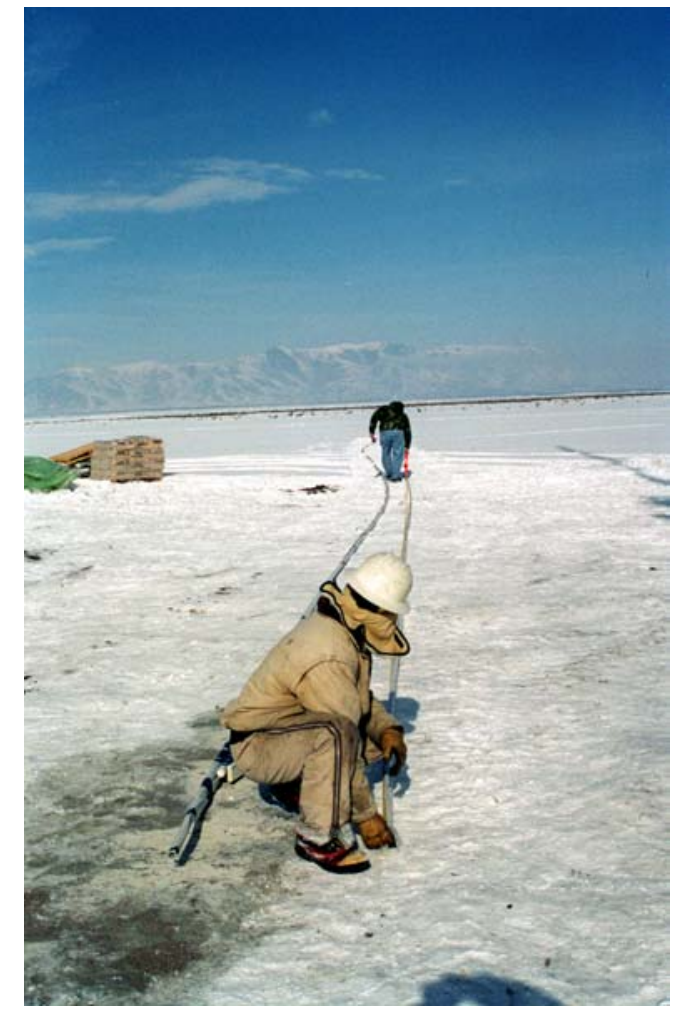

Figure 10. Instrument strings were measured to ensure that instruments would be installed at the depths selected by the project hydrologist. 


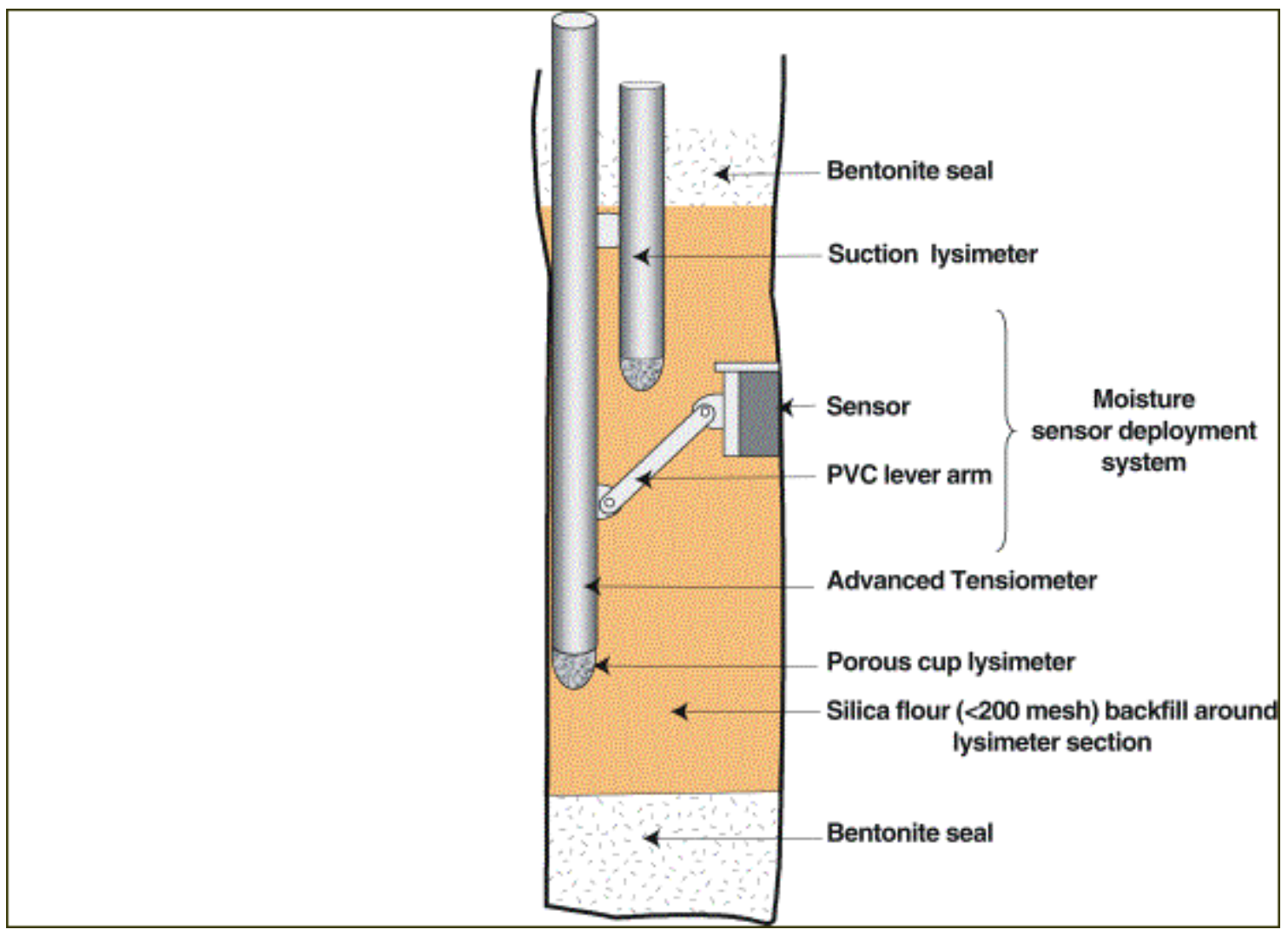

Figure 11. Instrument packages installed in boreholes at various locations to measure moisture content, potential, and collect water and gas samples from the vadose zone.
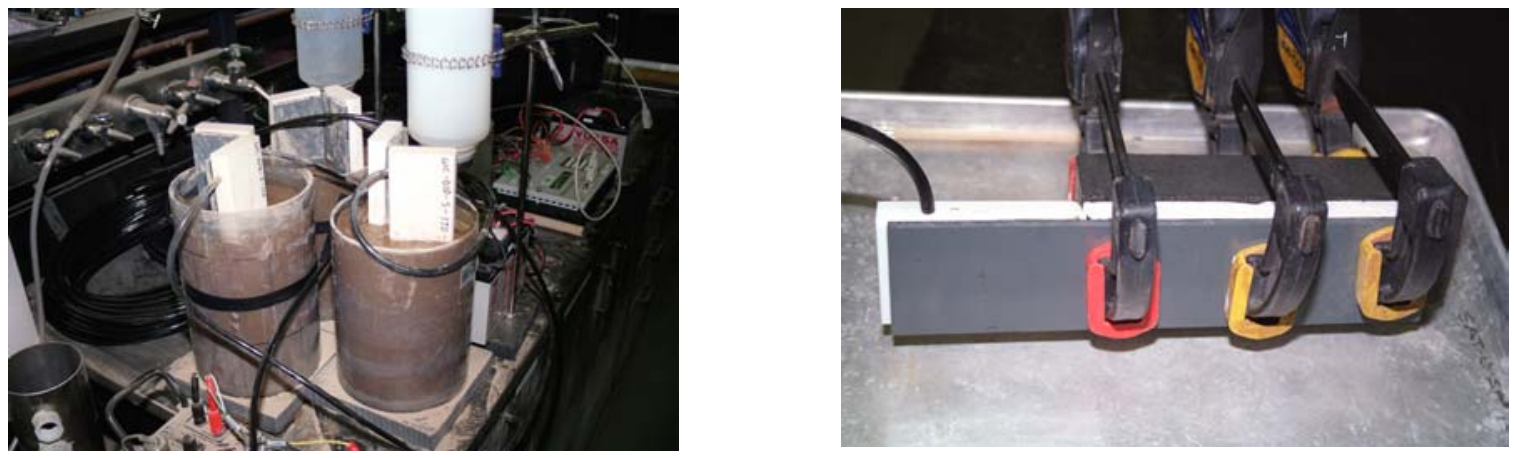

Figure 12. Moisture sensors planned for installation in sedimentary interbeds were calibrated using INEEL sediments (left). Moisture sensors planned for installation in basalt layers were calibrated using bricks of basalt (right). 


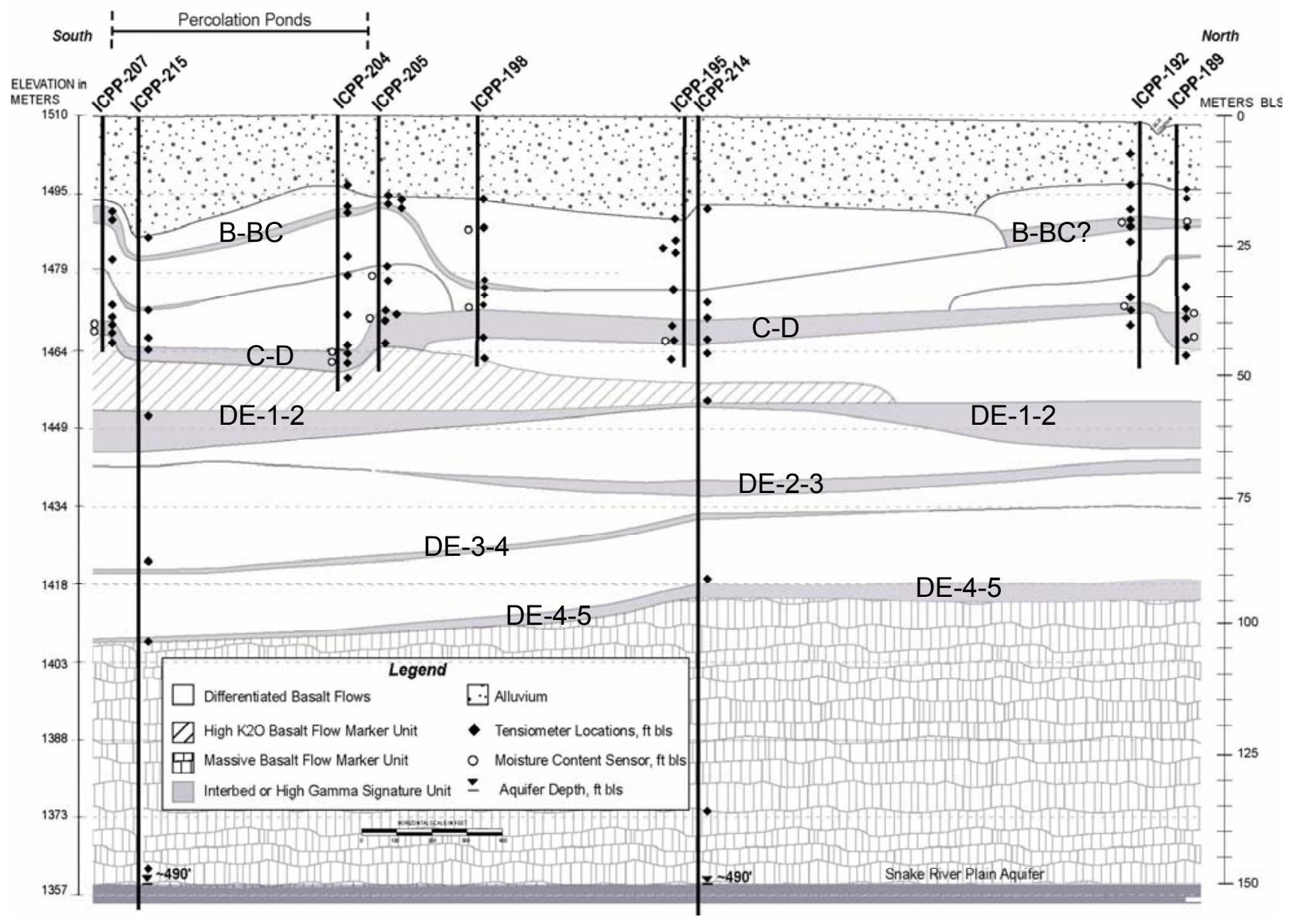

Figure 13. Stratigraphic correlation between instrumented boreholes at the Vadose Zone Research Park. Interbed names are derived from interbeds identified in nearby INEEL and U.S. Geological Survey wells at similar depths, bounded by similar marker beds. Well depth below land surface is relative to the surface datum at each well and based on driller's logs. Actual depths based on direct measurements to each sensor will be adjusted once measurements have been completed. 


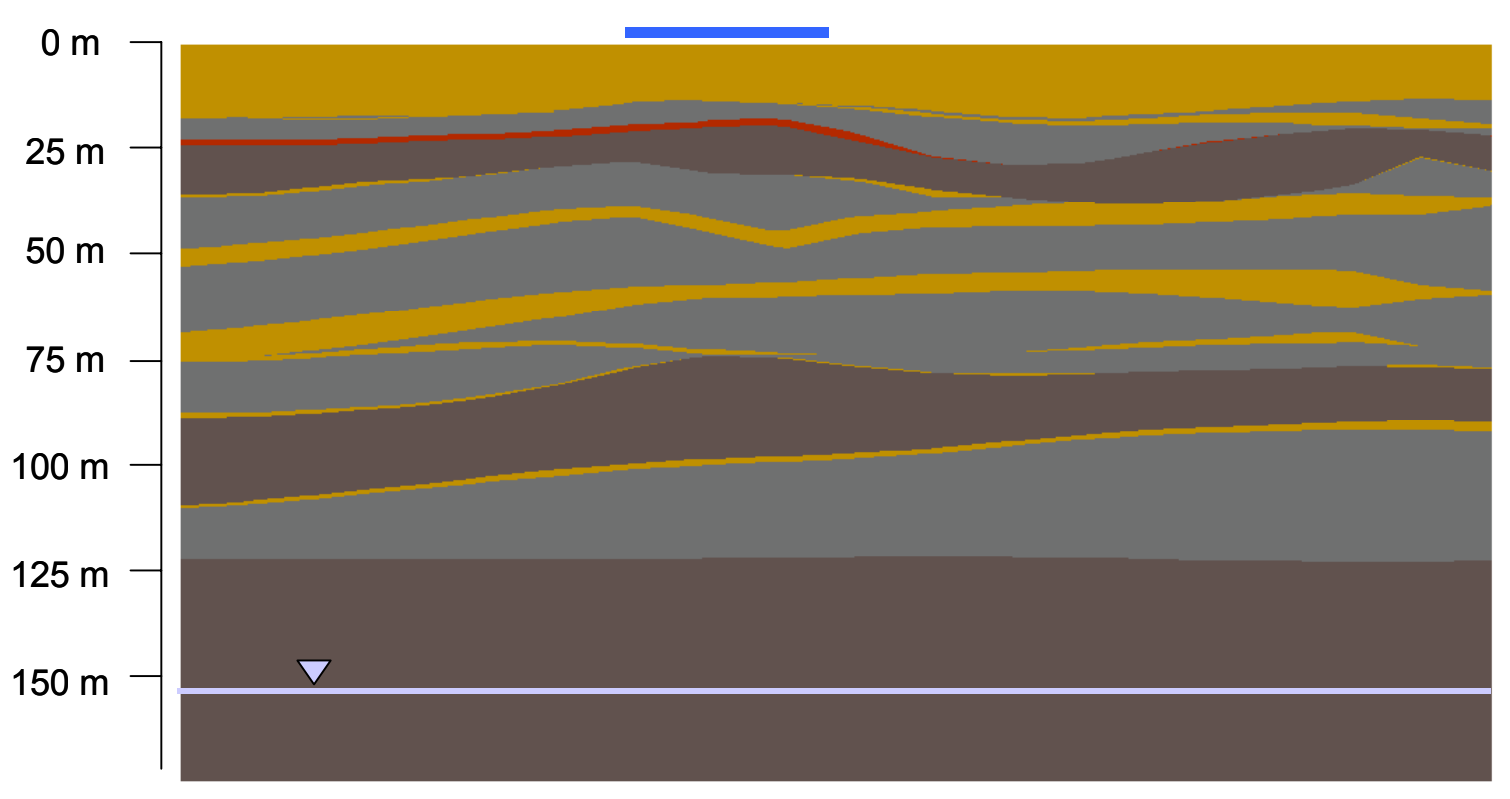

\section{Basalt Layers Sedimentary Layers}

Figure 14. Subsurface lithology of the Vadose Zone Research Park, visualized using the Environmental Visualization System. The view is a north-south slice through the center of the ponds, viewed from the east. 


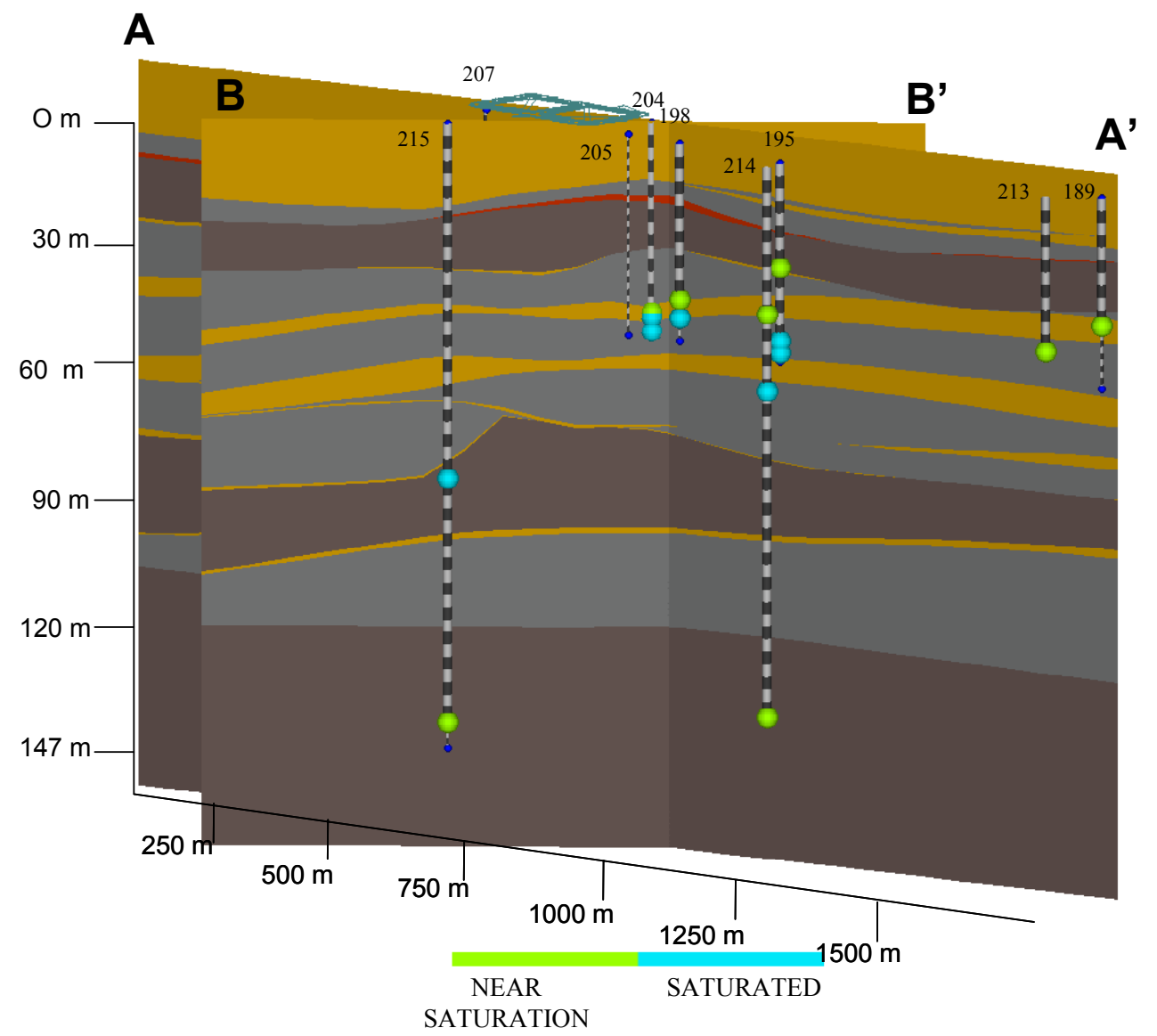

Figure 15. Preinfiltration subsurface moisture conditions. Cross Sections A-A' and B-B' are displayed in Figure 7. Blue bulbs represent saturated regions; green bulbs represent near saturation $(\sim 0$ cm hydraulic head). Borehole 207 is not visible from this angle; however, the subsurface is dry $(<0$-cm hydraulic head) within the monitoring region. 


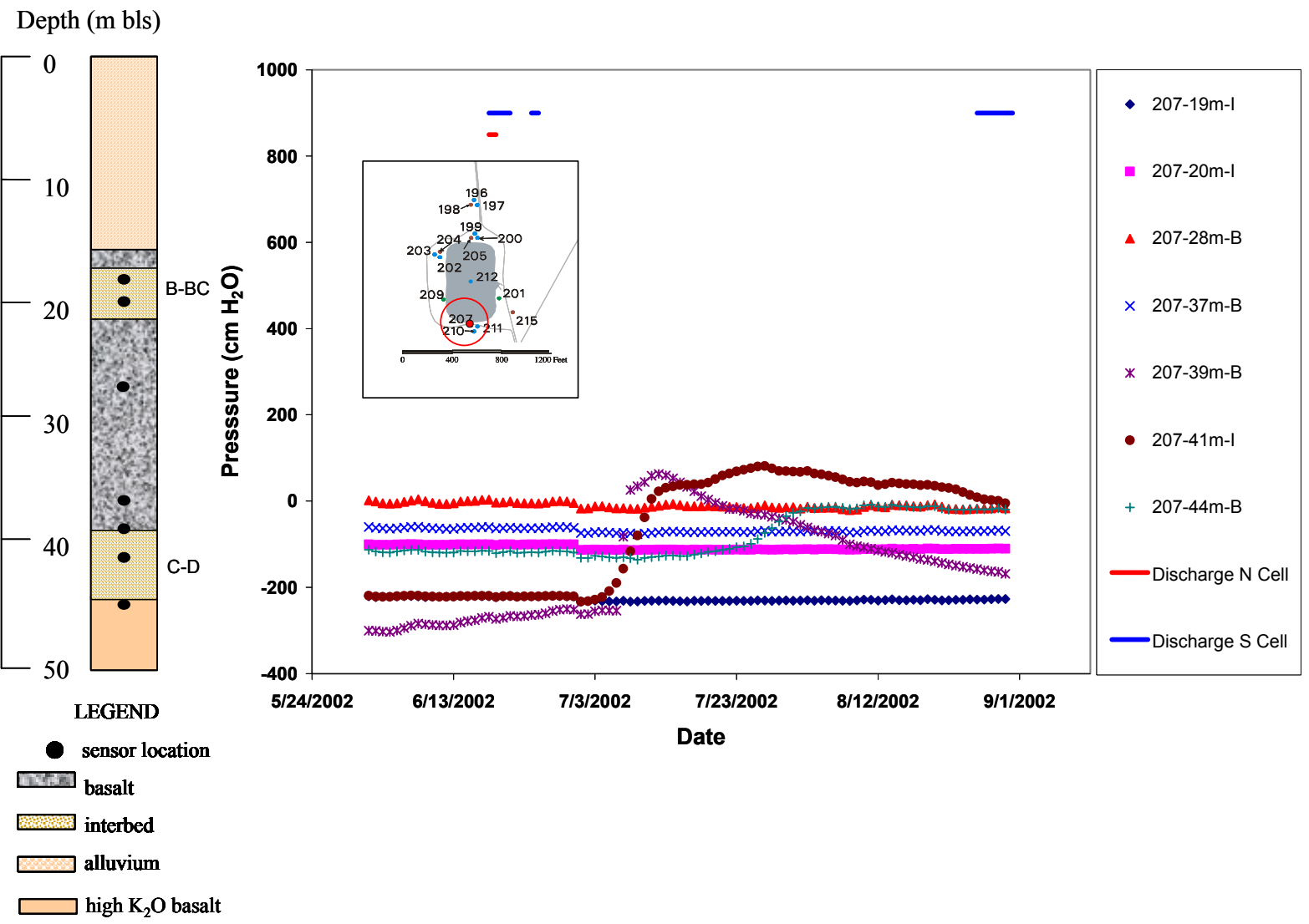

Figure 16. Tensiometer data for well 207, showing first water arrival from early discharge during June 18 through June 27, 2003 while testing pumps; B = basalt, I = interbed. 


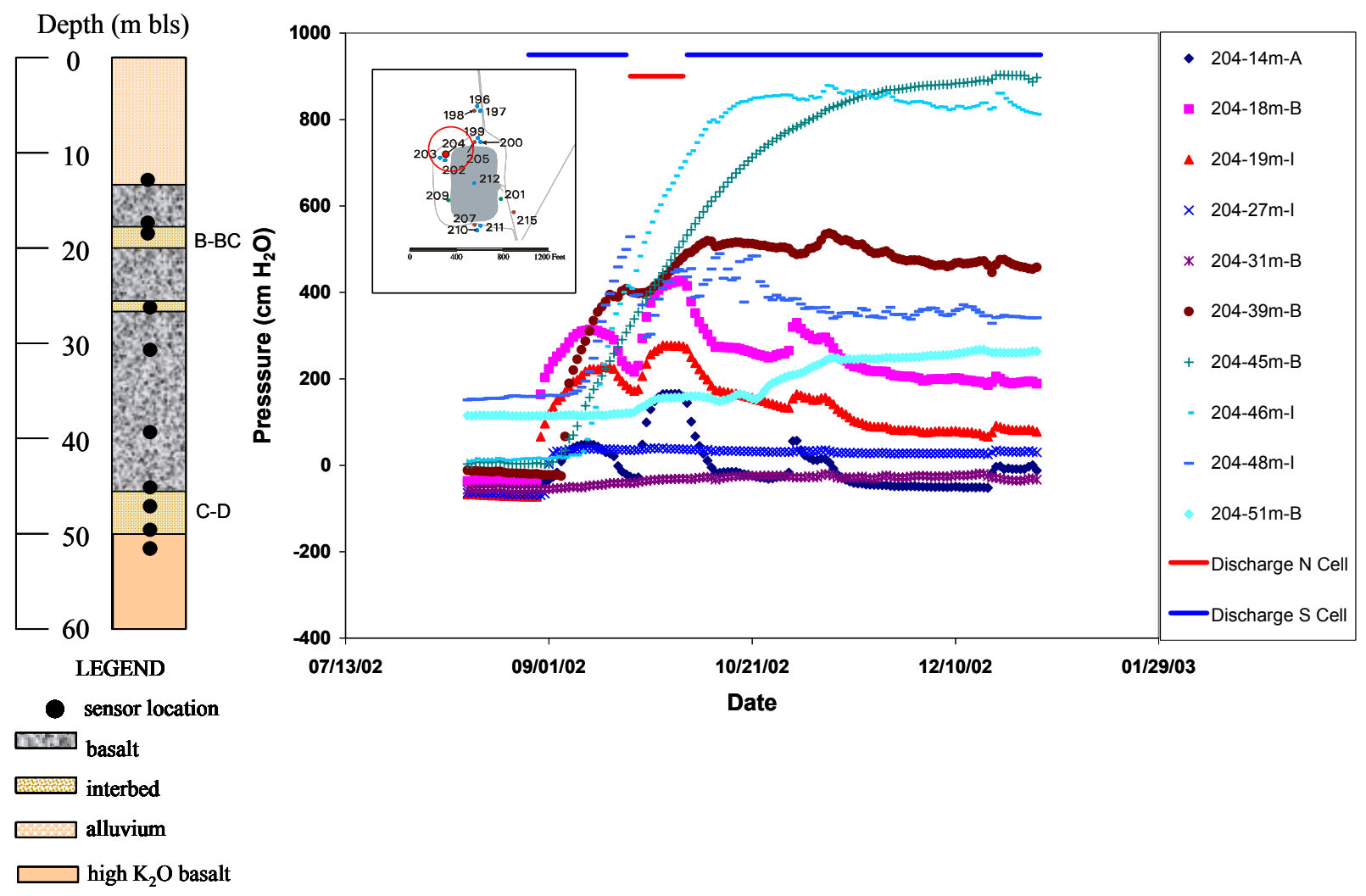

Figure 17. Well 204 tensiometer response to initial water arrival and changes in discharge location for the months of August through October 2002. Pressure spikes in early November reflect a rapid increase in discharge volume, which lasted about 4 days. Tensiometers in this well were pulled for calibration December 19, 2002, also showing a spike in pressure. $\mathrm{A}=$ alluvium, $\mathrm{B}=$ basalt, $\mathrm{I}=$ interbed. 


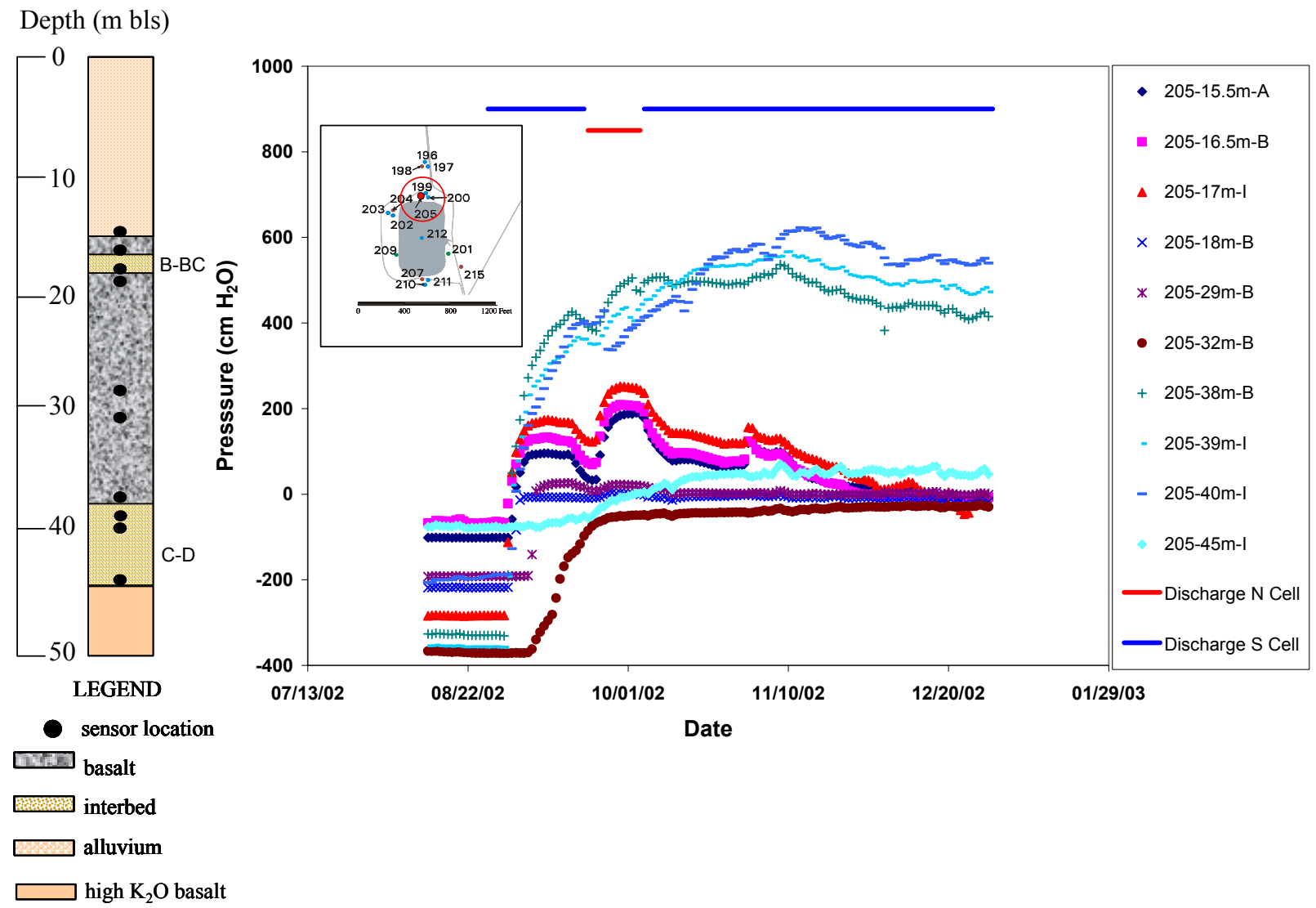

Figure 18. Well 205 tensiometer responses to initial water arrival and changes in discharge location for the months of August through October 2002. Pressure spikes in early November reflect a rapid increase in discharge volume, which lasted about 4 days. $\mathrm{A}=$ alluvium, $\mathrm{B}=$ basalt, $\mathrm{I}=$ interbed. 


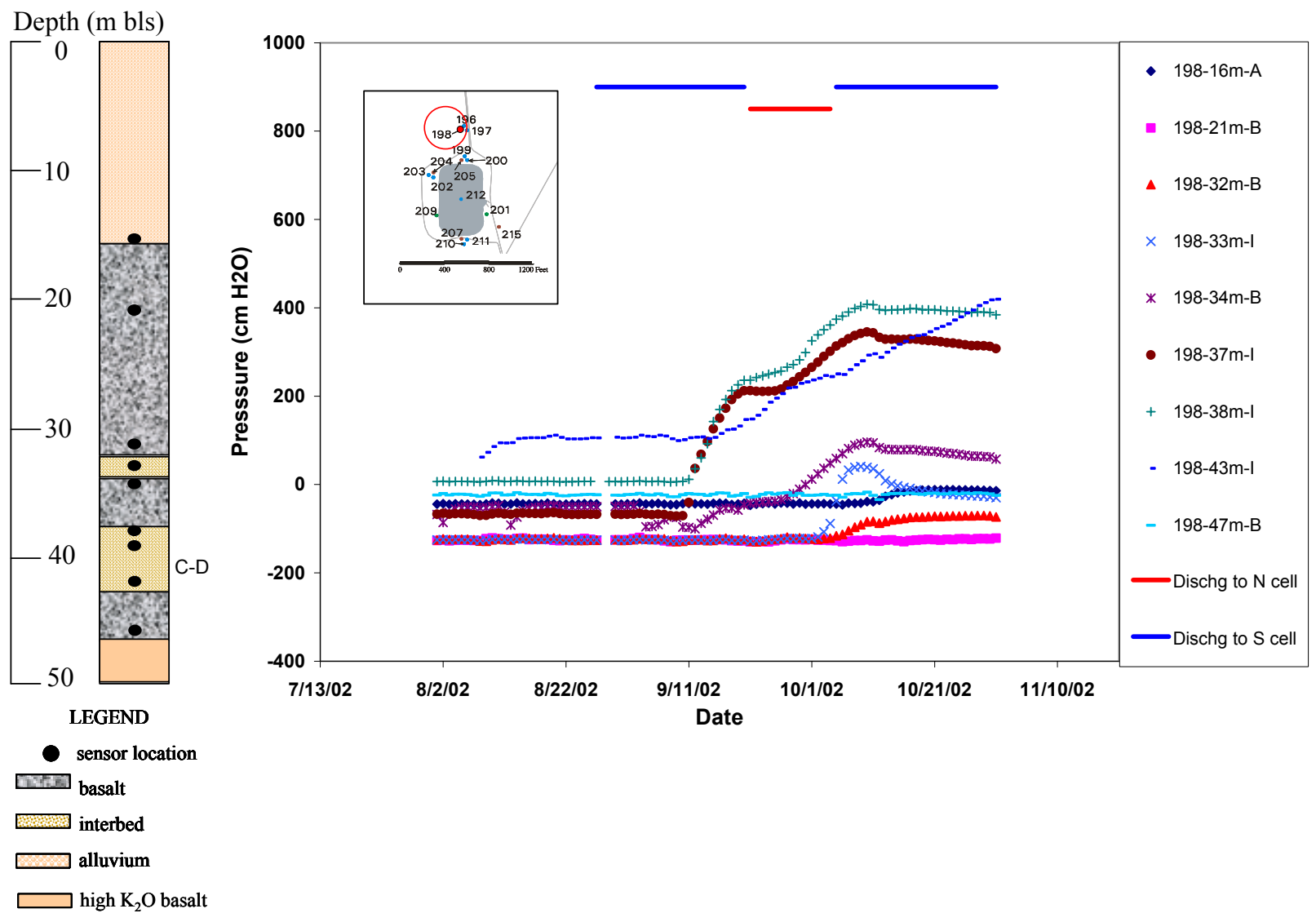

Figure 19. Well 198 tensiometer responses to initial water arrival and changes in discharge location for the months of August through October 2002. A = alluvium, B = basalt, $\mathrm{I}=$ interbed. 


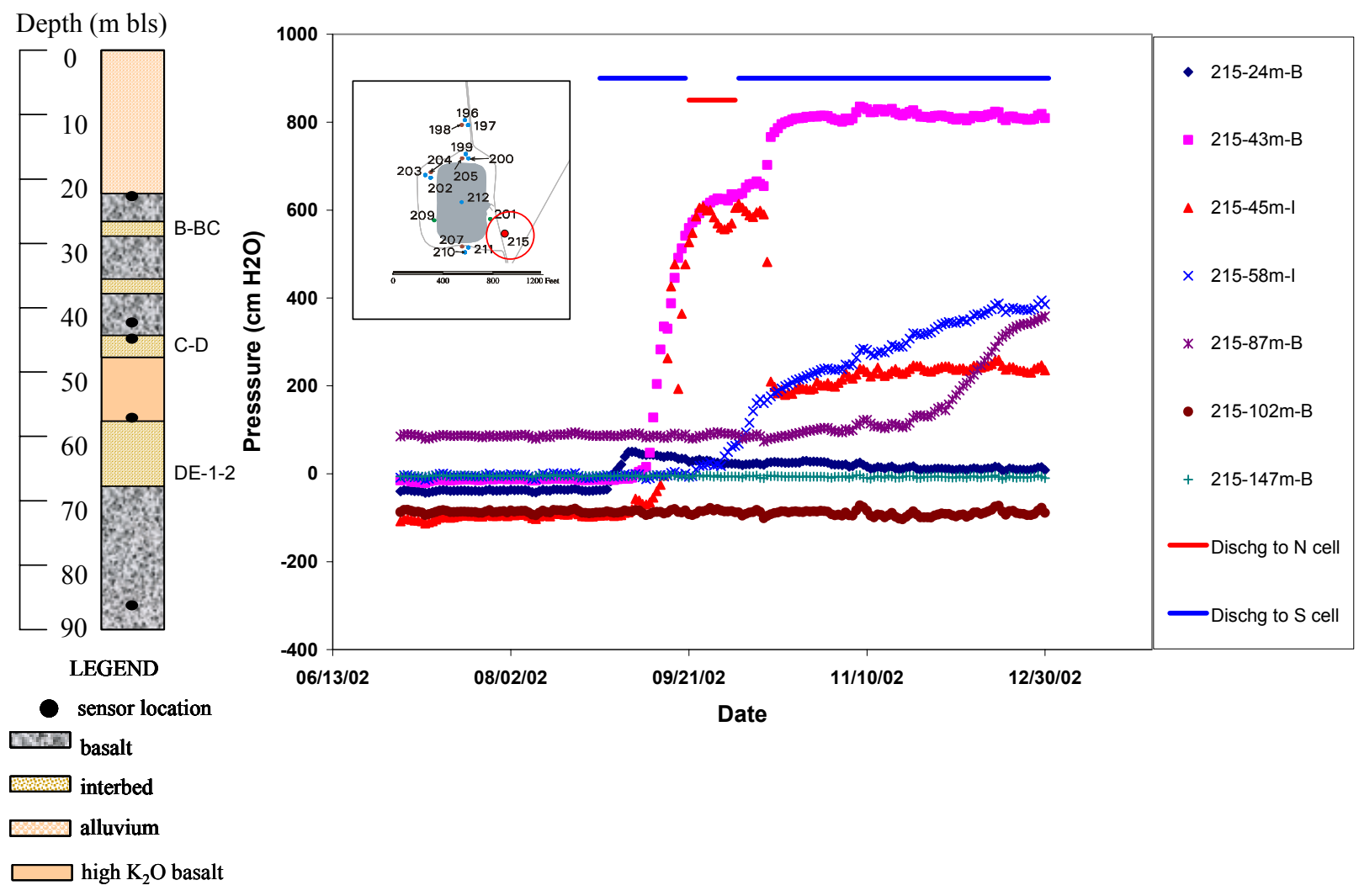

Figure 20. Well 215 tensiometer responses to initial water arrival and changes in discharge location for the months of August through October 2002. Pressure spikes in early November reflect a rapid increase in discharge volume, which lasted about 4 days. $\mathrm{A}=$ alluvium, $\mathrm{B}=$ basalt, $\mathrm{I}=$ interbed. 


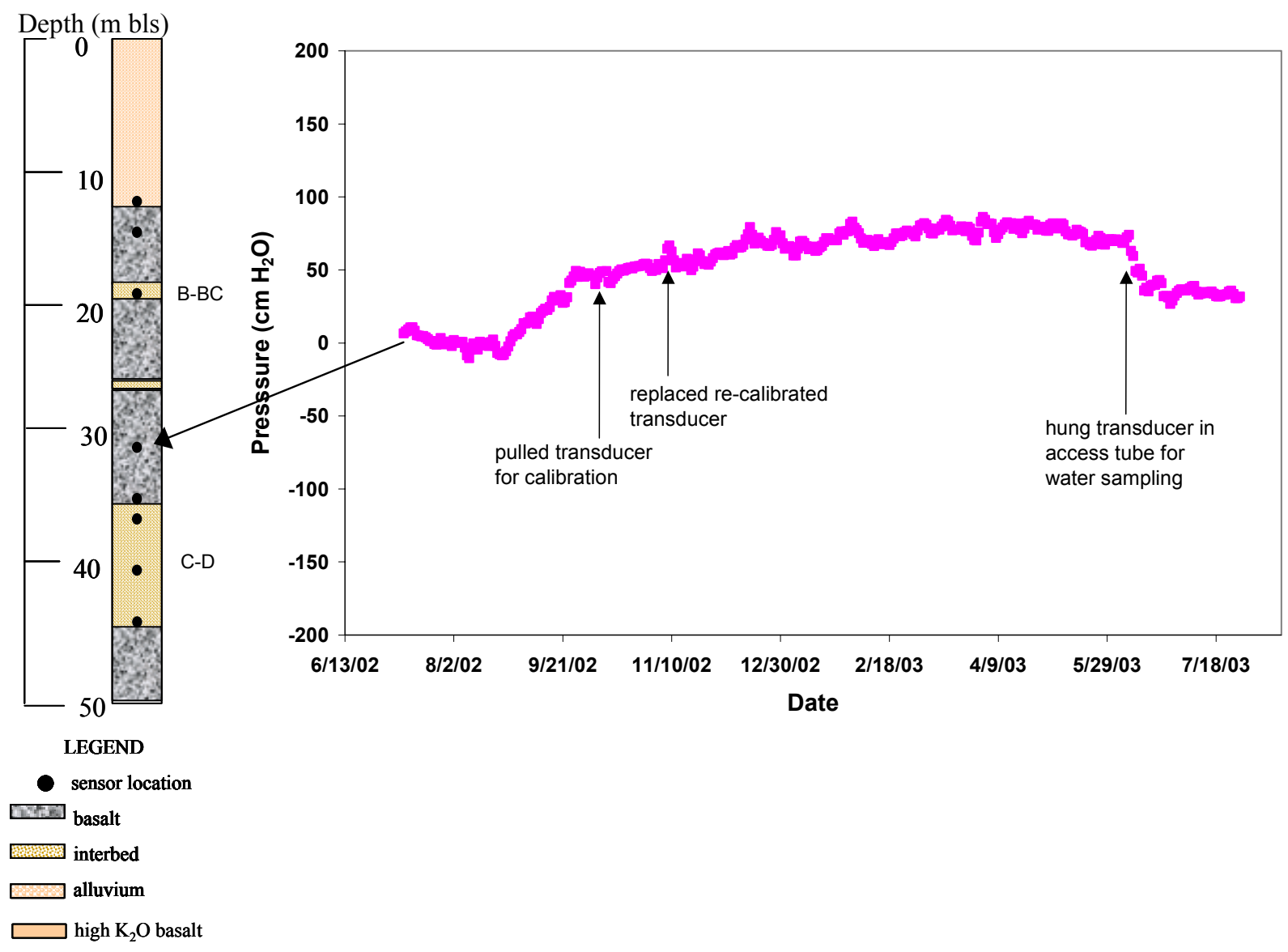

Figure 21. Well 189 advanced tensiometer pressure readings at 31-m bls. Pressure began to increase in early September 2002 and reached a steady value of approximately $70-\mathrm{cm}$ positive pressure in March 2003. 


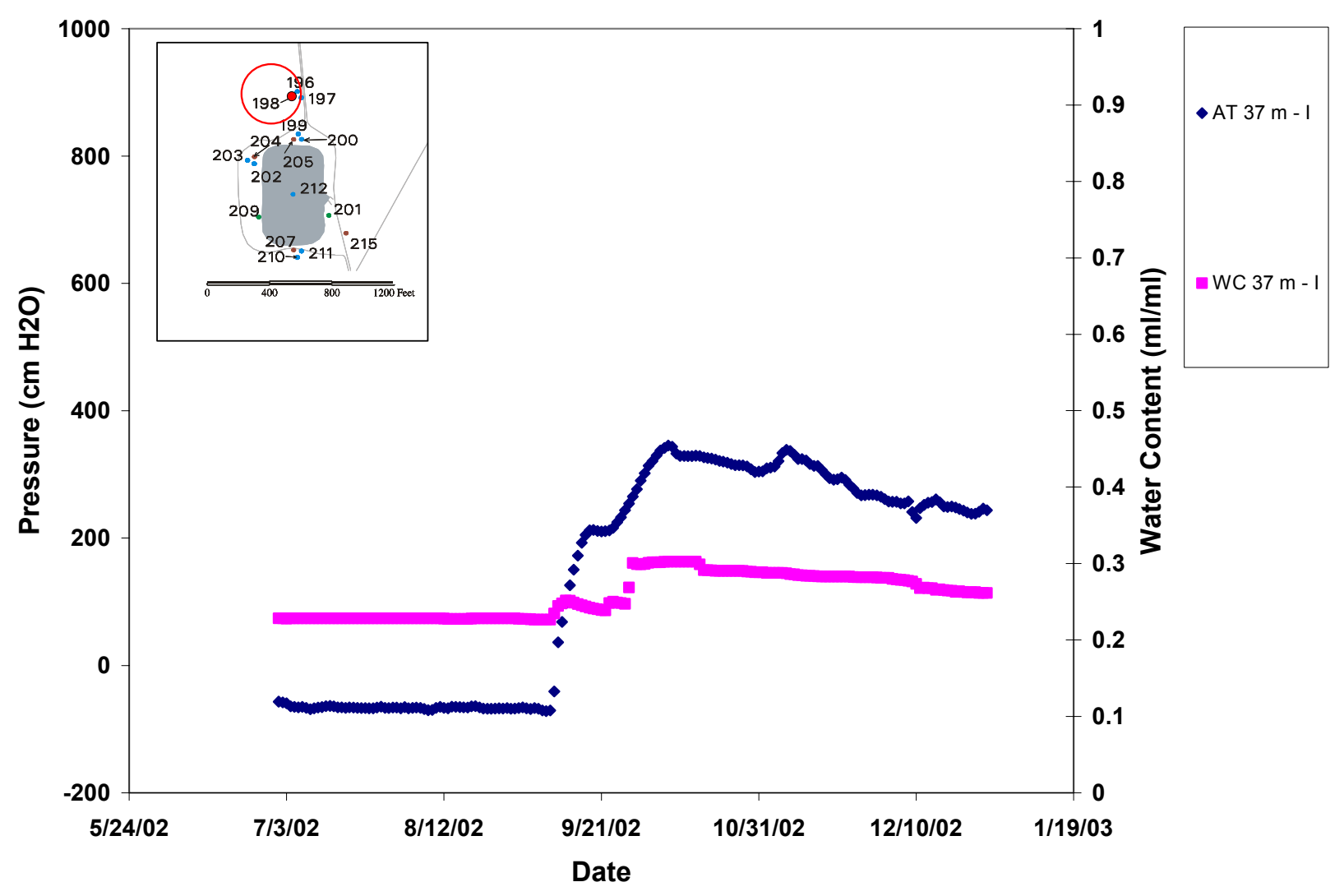

Figure 22. Tensiometer and water content sensors, showing response to first water arrival in well 198 at 37-m below land surface within the C-D interbed on September 11, 2002. 


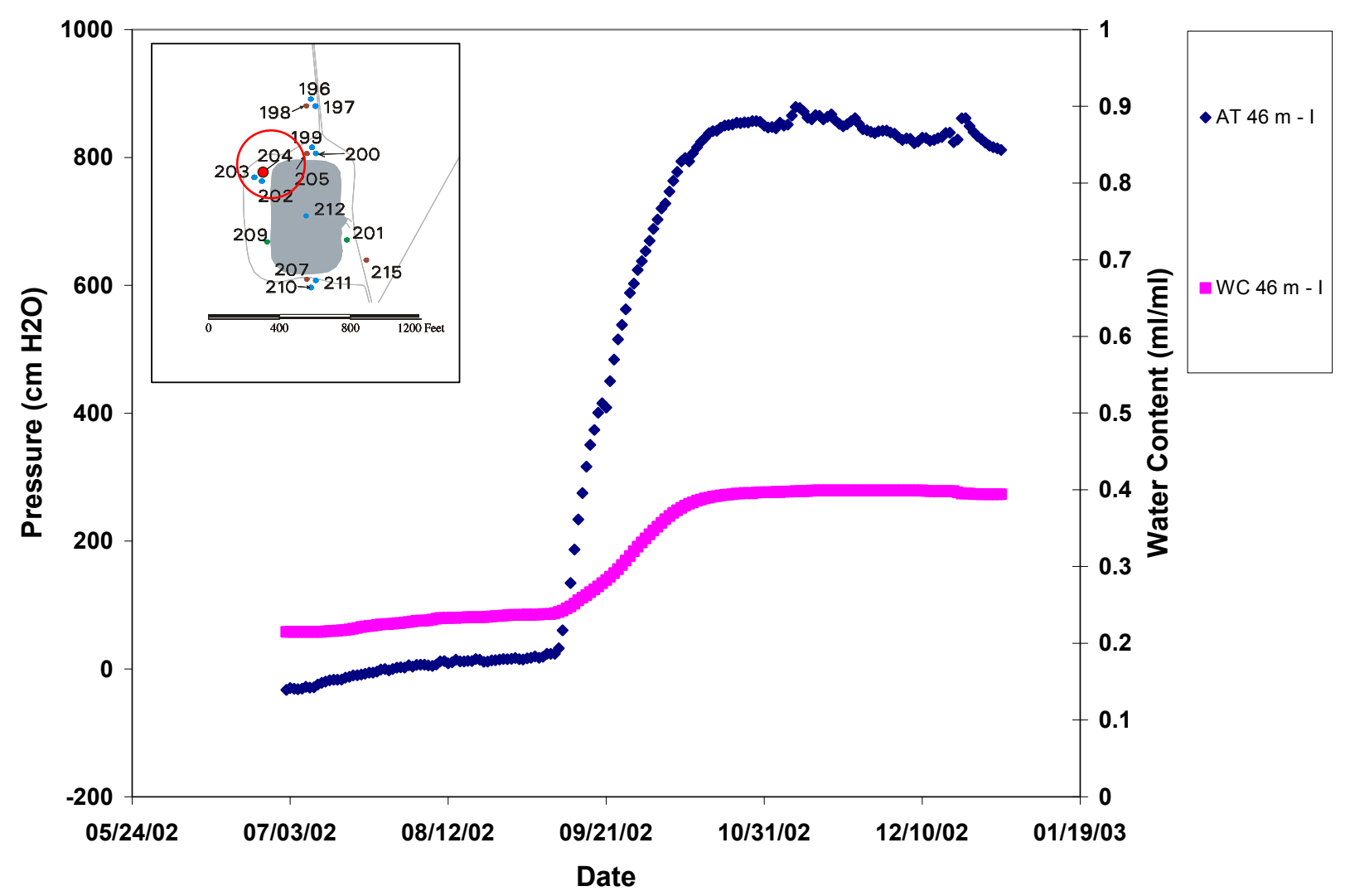

Figure 23. Tensiometer and water content sensors, showing response to first water arrival in well 204 at 46-m below land surface in the C-D interbed on September 10, 2002. 


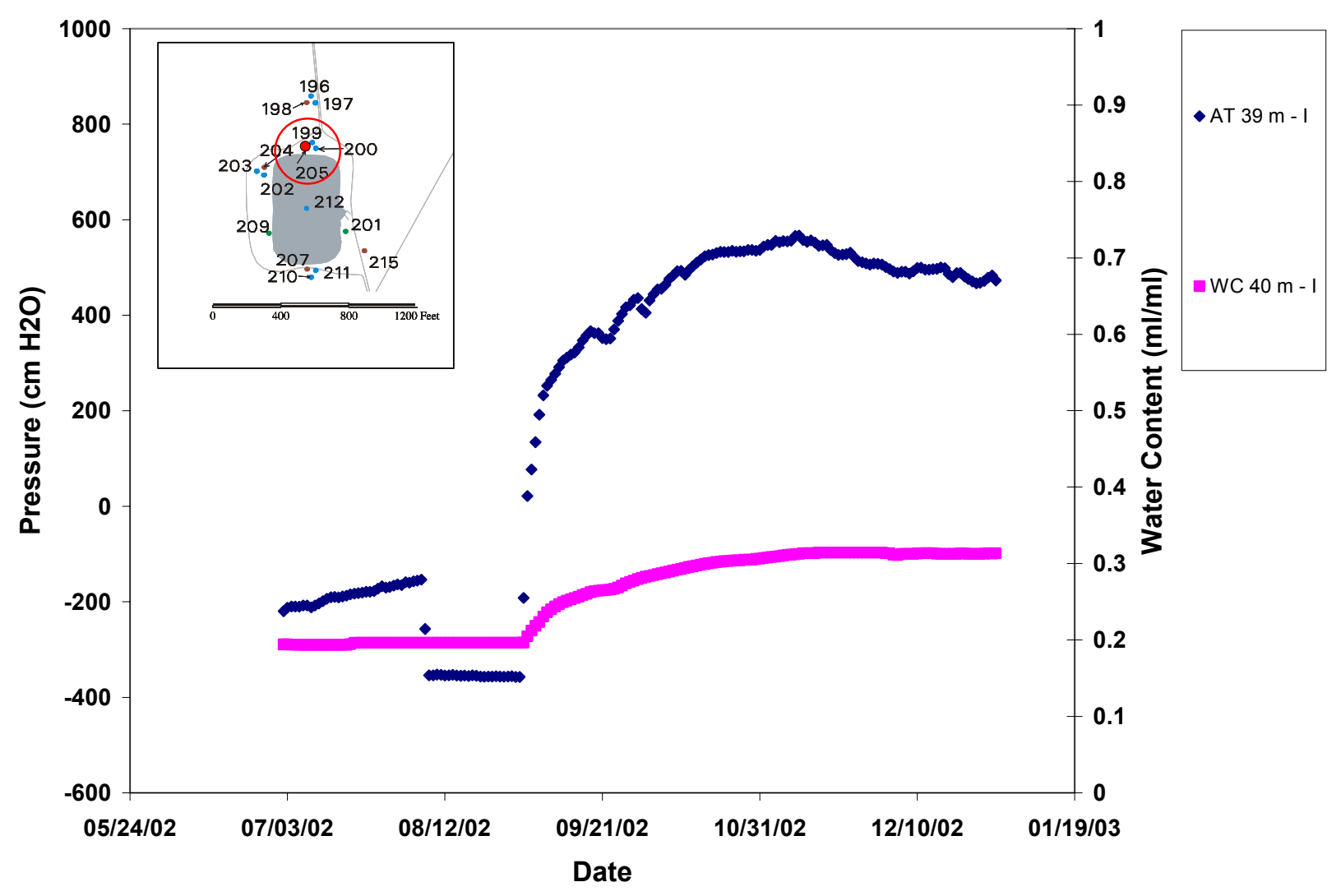

Figure 24. Tensiometer and water content sensors showing response to first water arrival in well 205 at approximately 40-m below land surface in the C-D interbed on September 2, 2002. 


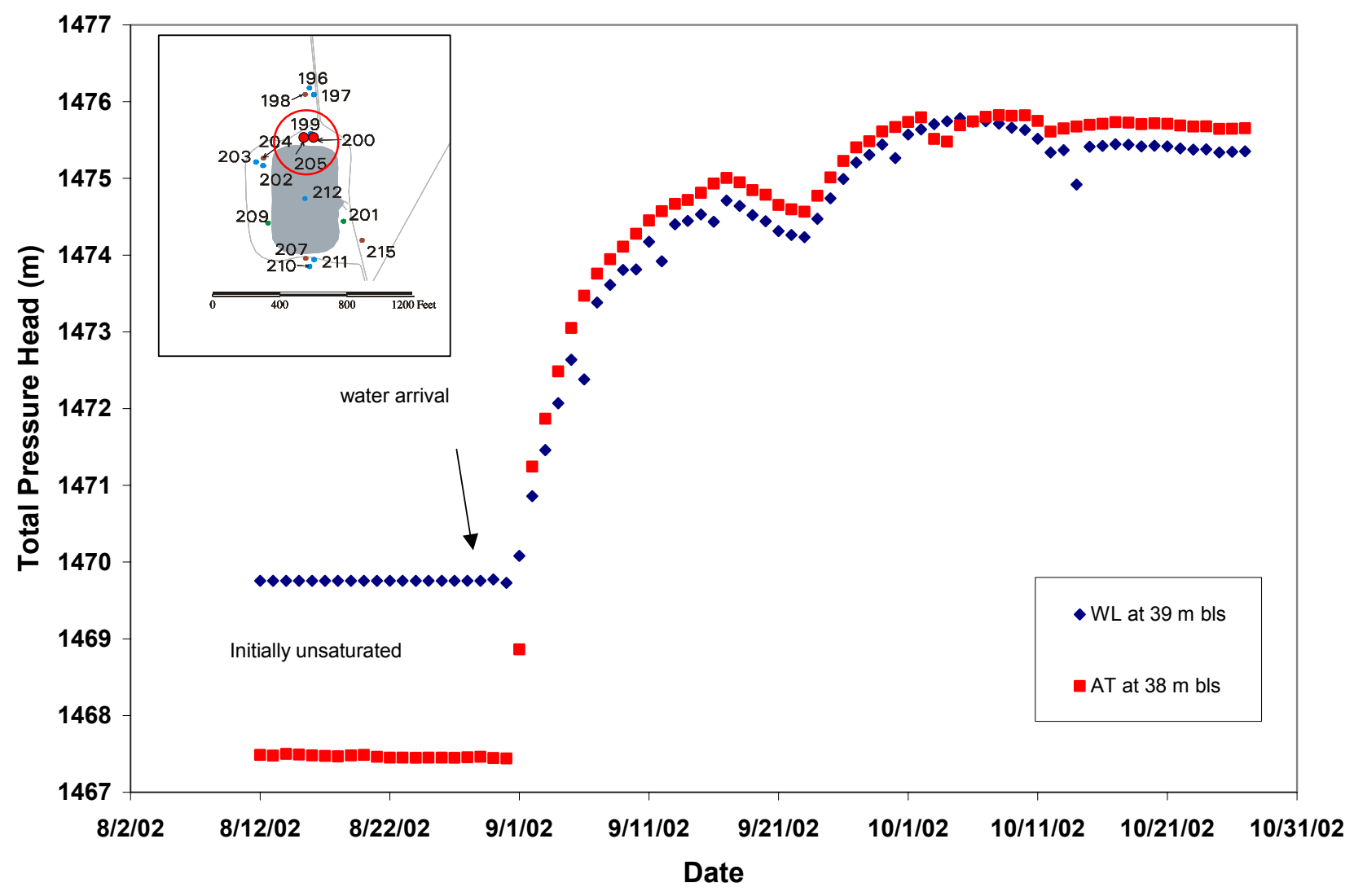

Figure 25. Comparison between tensiometer (AT) pressure head data and water level (WL) sensor data in the instrumeneted borehole 205 and the perched water monitoring well 200 during rapid infiltration. Both sensors are located a few meters apart just north of the pond in the C-D interbed at approximately 40$\mathrm{m}$ bls. The subsurface was initial unsaturated, therefore the tensiometer recorded a negative pressure before infiltration, while the WL sensor recorded zero $\mathrm{cm}$ of water pressure, since standing water was not present in the monitoring well. Difference in pressure values may be due to uncertainty in exact sensor depth below land surface. The values will be adjusted once the depths are measured for each sensor. 


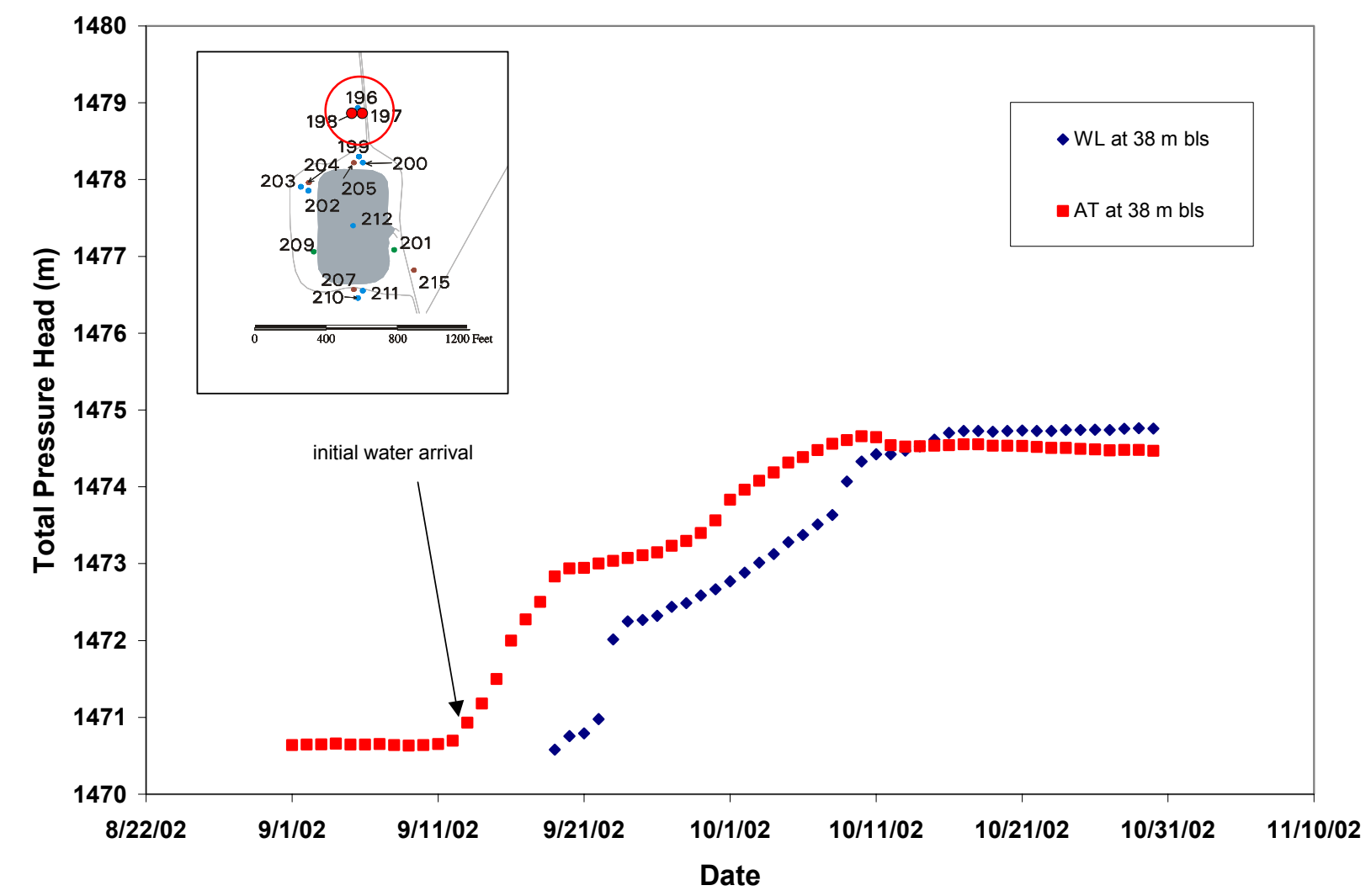

Figure 26. Comparison between tensiometer (AT) and water level (WL) sensor pressure head data in the instrumented borehole 198 and vadose zone monitoring well 197 during slow infiltration. Both sensors are located approximately $200-\mathrm{m}$ north of the pond in the C-D interbed at approximately $38-\mathrm{m}$ bls. The WL measurements lag several days behind the AT sensor in response to slow water infiltration and took almost 2 weeks to stabilize at the same pressure head as the AT. The slight difference in head values once stabilized may be due to uncertainties in actual sensor depth below land surface. The values will be adjusted once the depths are measured for each sensor. 


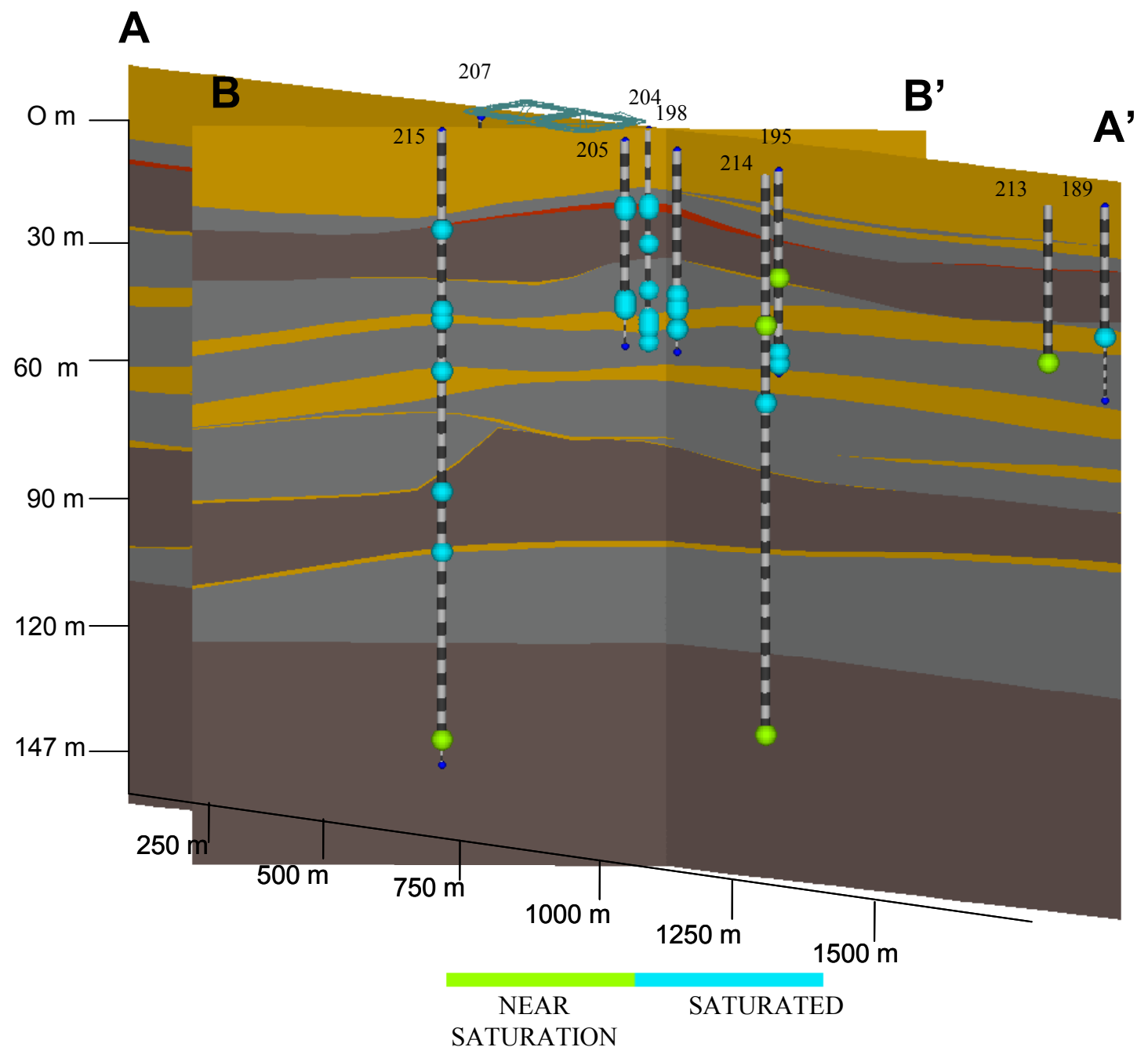

Figure 27. Hydraulic conditions after one month (October 31,2002) of continuous discharge to the south cell at the Vadose Zone Research Park percolation pond. Blue bulbs represent saturated conditions; green bulbs represent near saturation ( $\sim 0 \mathrm{~cm}$ hydraulic pressure head). 


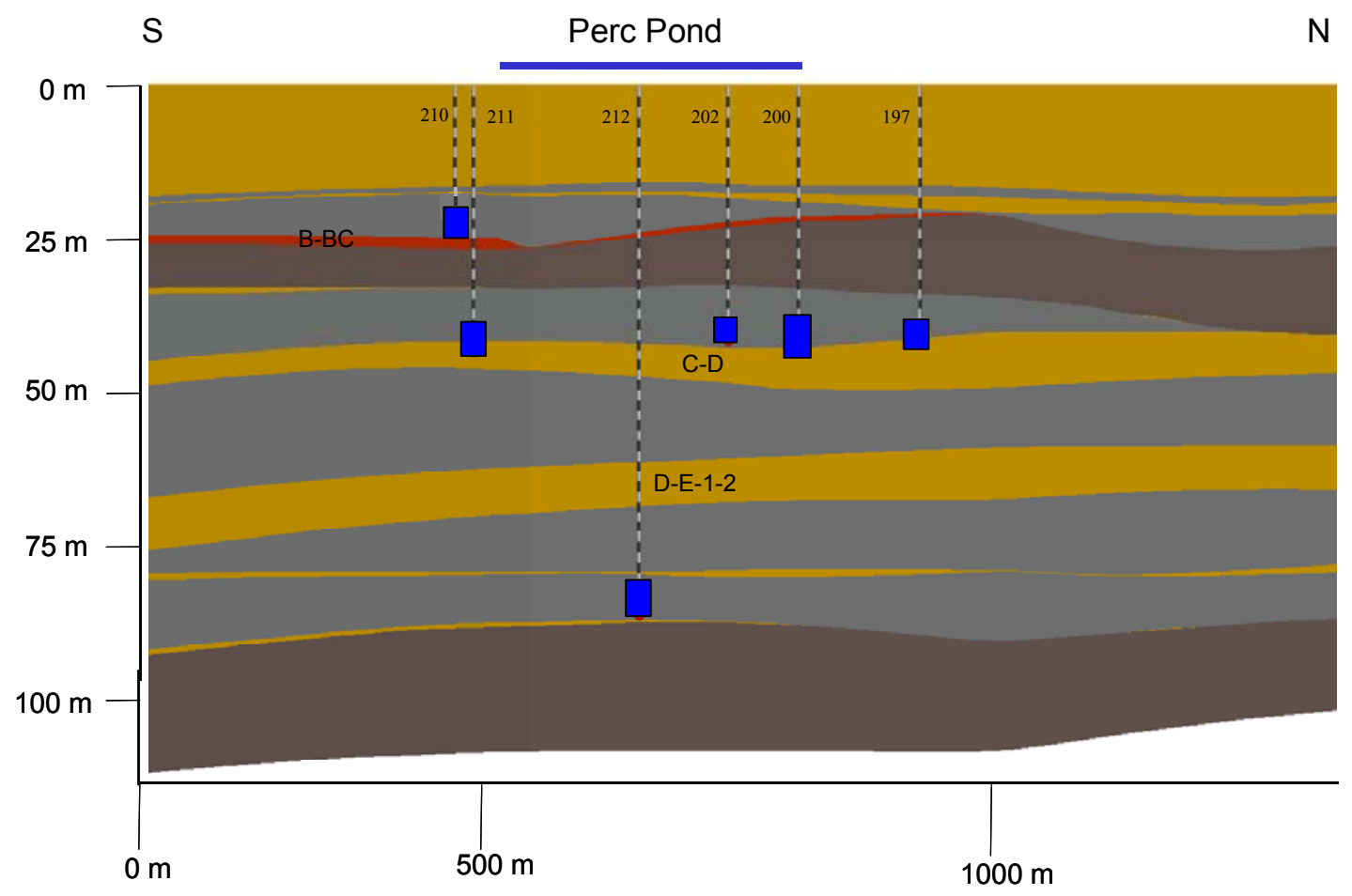

Figure 28. Perched water levels measured in vadose zone monitoring wells at the Vadose Zone Research Park March 2003. All these wells were initially dry before pond discharge. 


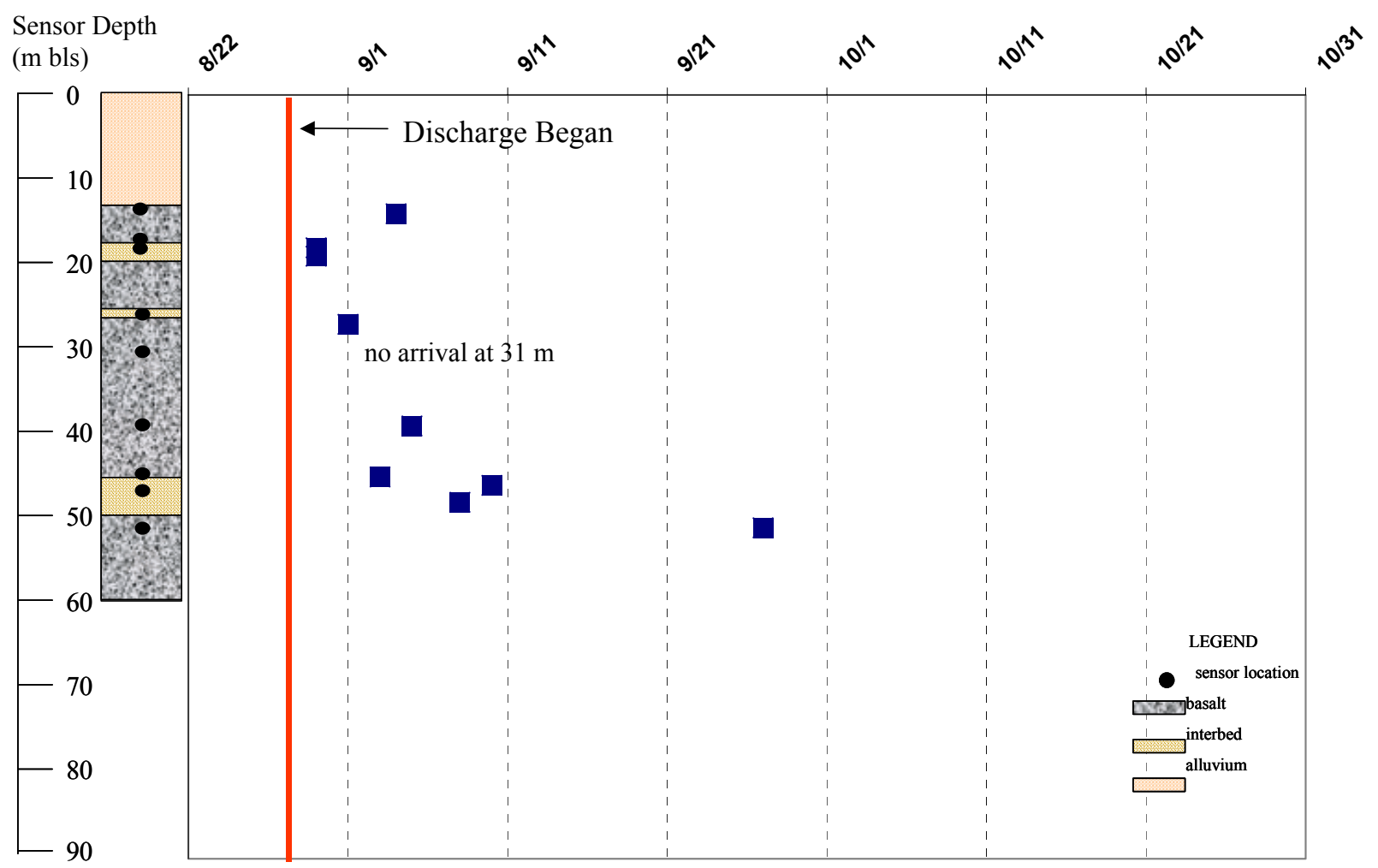

Figure 29. Water arrival sequence beneath the Vadose Zone Research Park percolation pond for borehole 204, based on tensiometer data collected from July 1, 2002 through October 31, 2002. This is an example of preferential type flow where water arrival occurred non-sequentially with depth. 


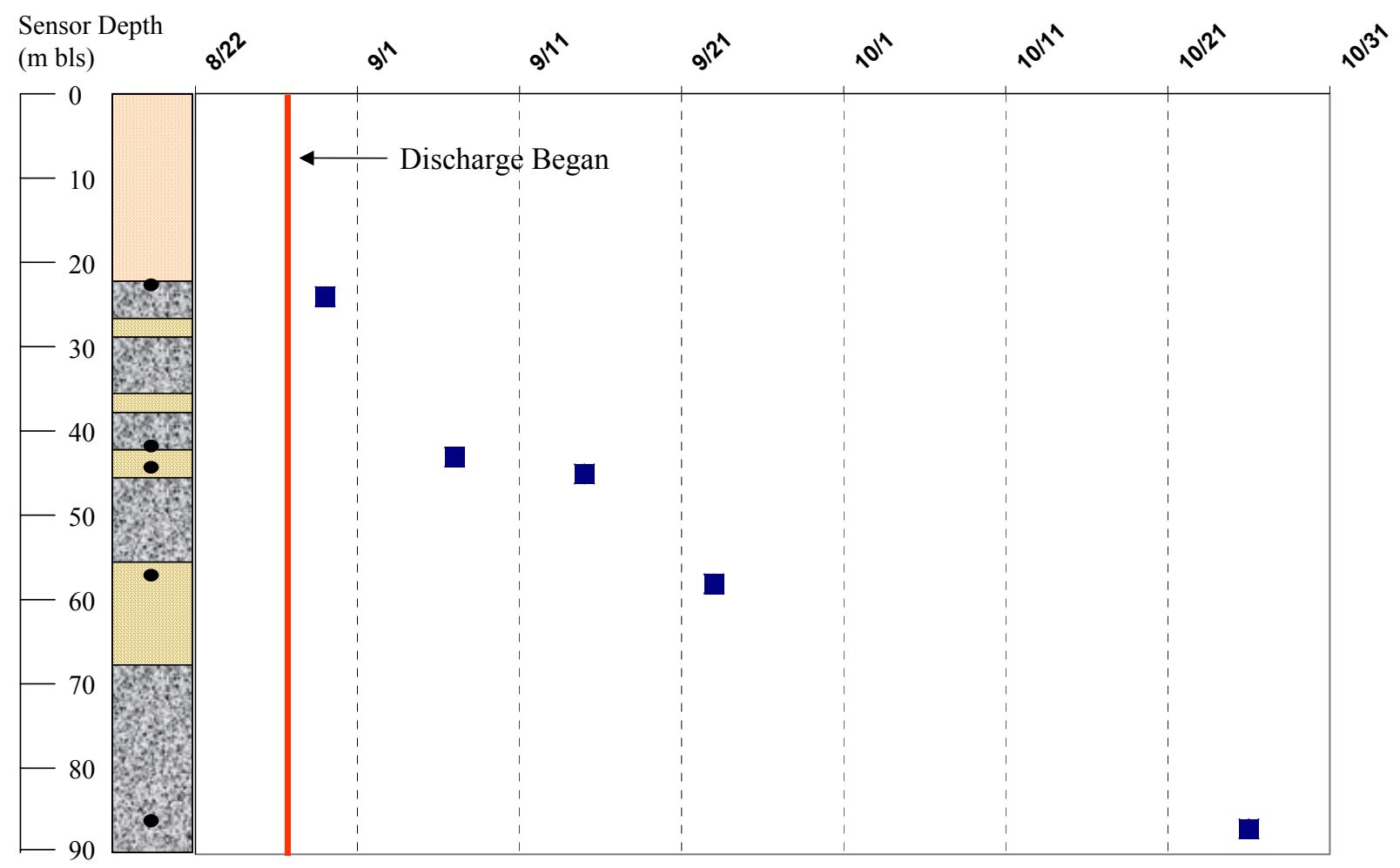

Figure 30. Water arrival sequence beneath the Vadose Zone Research Park percolation pond for borehole 215, based on tensiometer data collected from July 1, 2002 through October 31, 2002. This is an example of diffuse type flow where water arrives sequentially with depth. This was the only instrumented borehole that exhibited this type of water arrival behavior. 


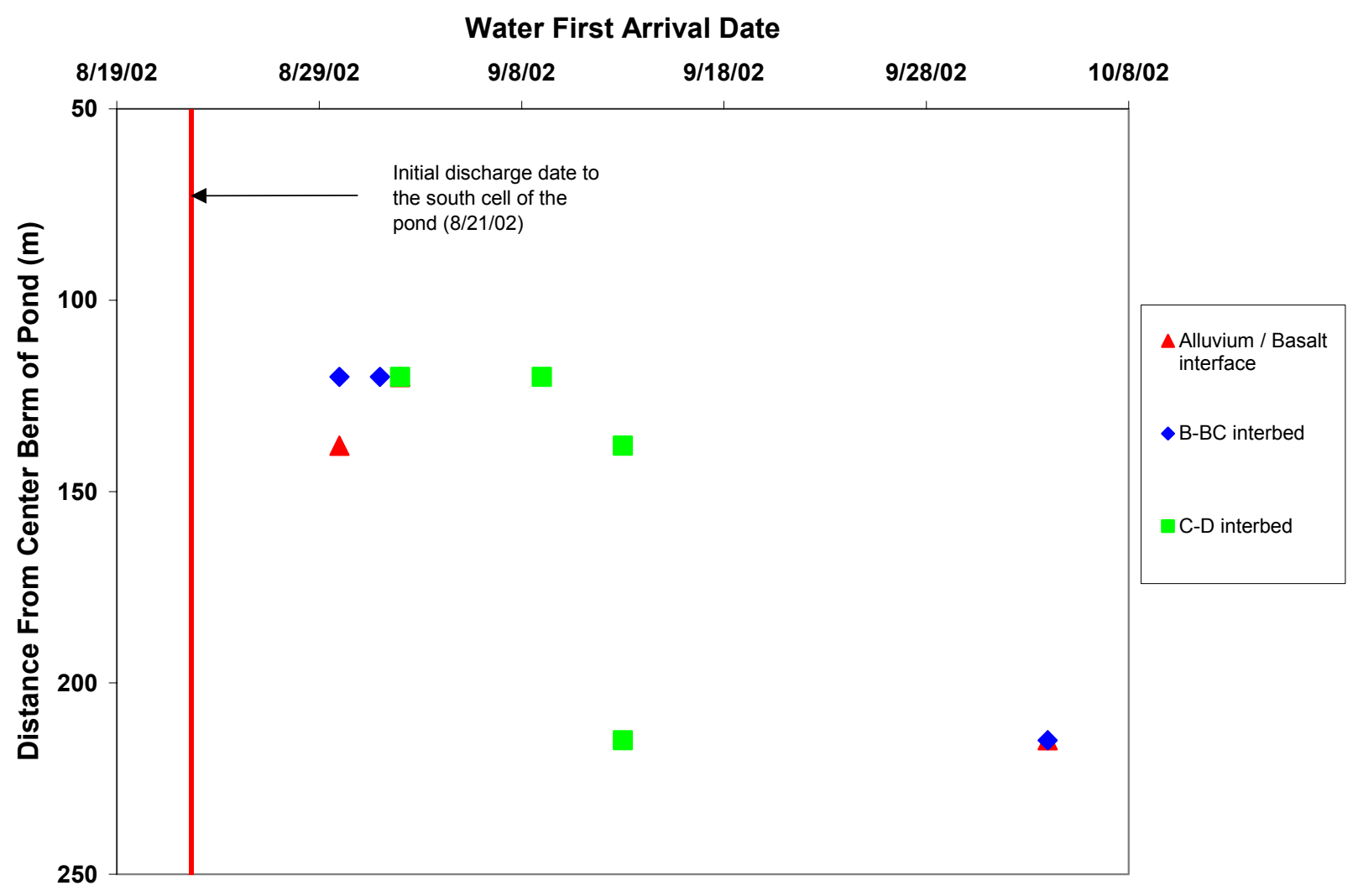

Figure 31. Grouped lithology water arrival dates as a function of lateral distance from the center berm of the pond for the alluvium/basalt interface, the B-BC interbed, and the C-D interbed for wells 198, 204, 205, and 215. 


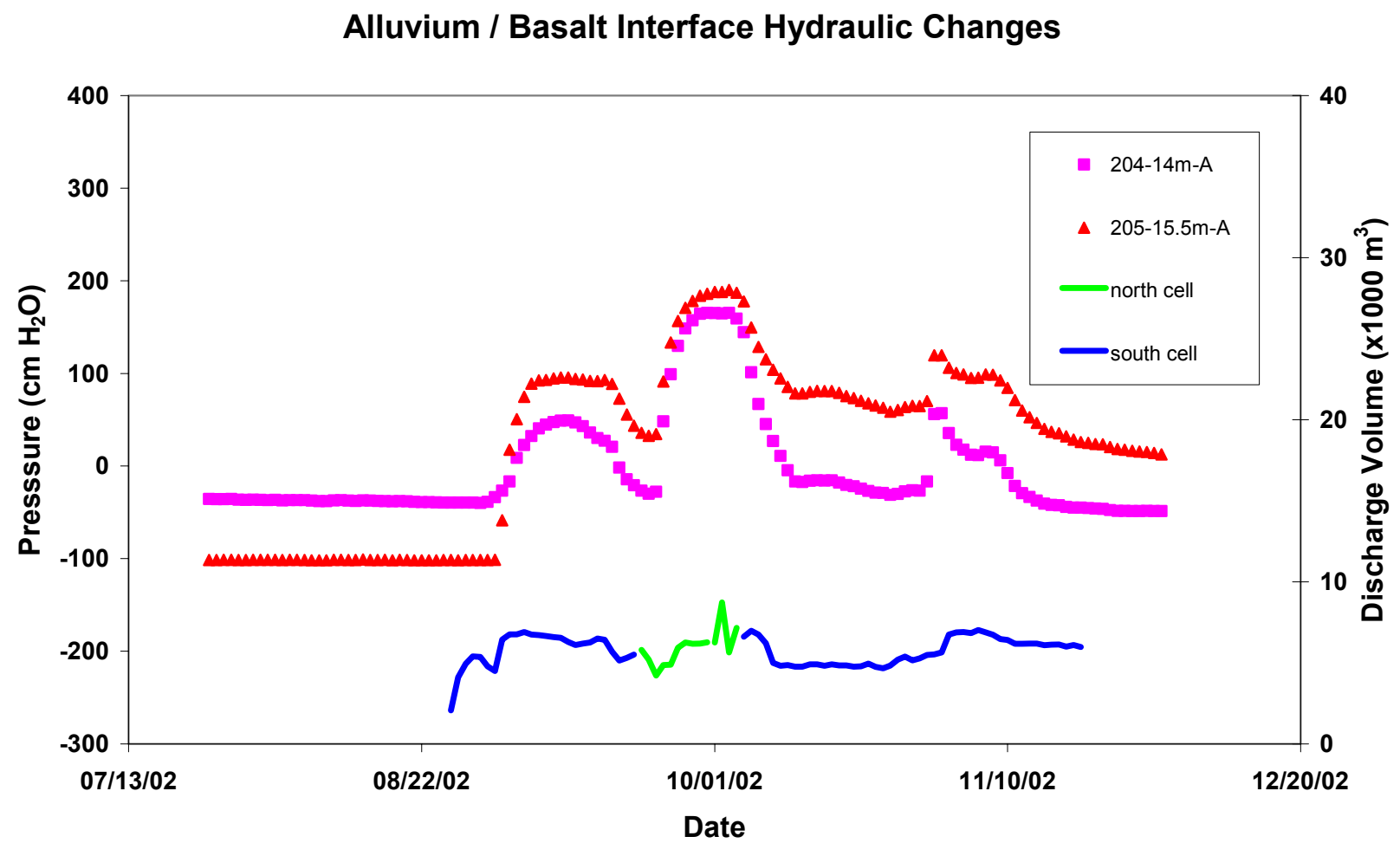

Figure 32. Example of changes in hydraulic pressure possibly due to flushing of fines from large pores during rapid infiltration or encountering fast pathways. Pressure peak reached during initial infiltration for both wells was about a meter higher than pressure observed after 3 months of continuous discharge to the pond. 


\section{B-C Interbed Hydraulic Changes}

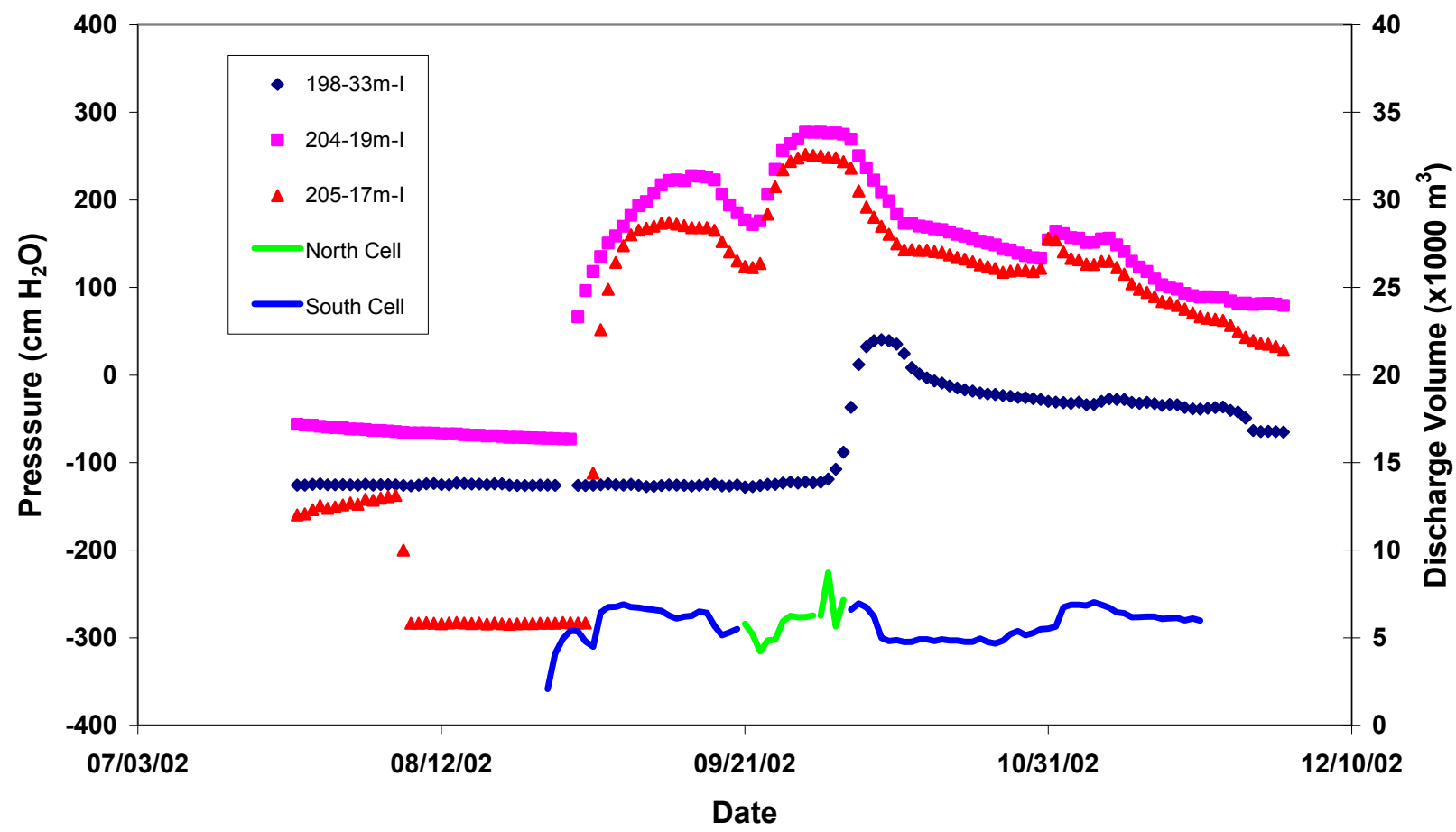

Figure 33. Example of changes in hydraulic pressure possibly due to flushing of fines from large pores during rapid infiltration or encountering fast pathways. Pressure peak reached during initial infiltration for 204 and 205 was about a meter higher than pressure observed after 3 months of continuous discharge to the pond. Pressure peak reached in well 198 was about $0.5-\mathrm{m}$ higher initially than what was observed 3 months after continuous discharge to the pond. 


\section{C-D Interbed Hydraulic Changes}

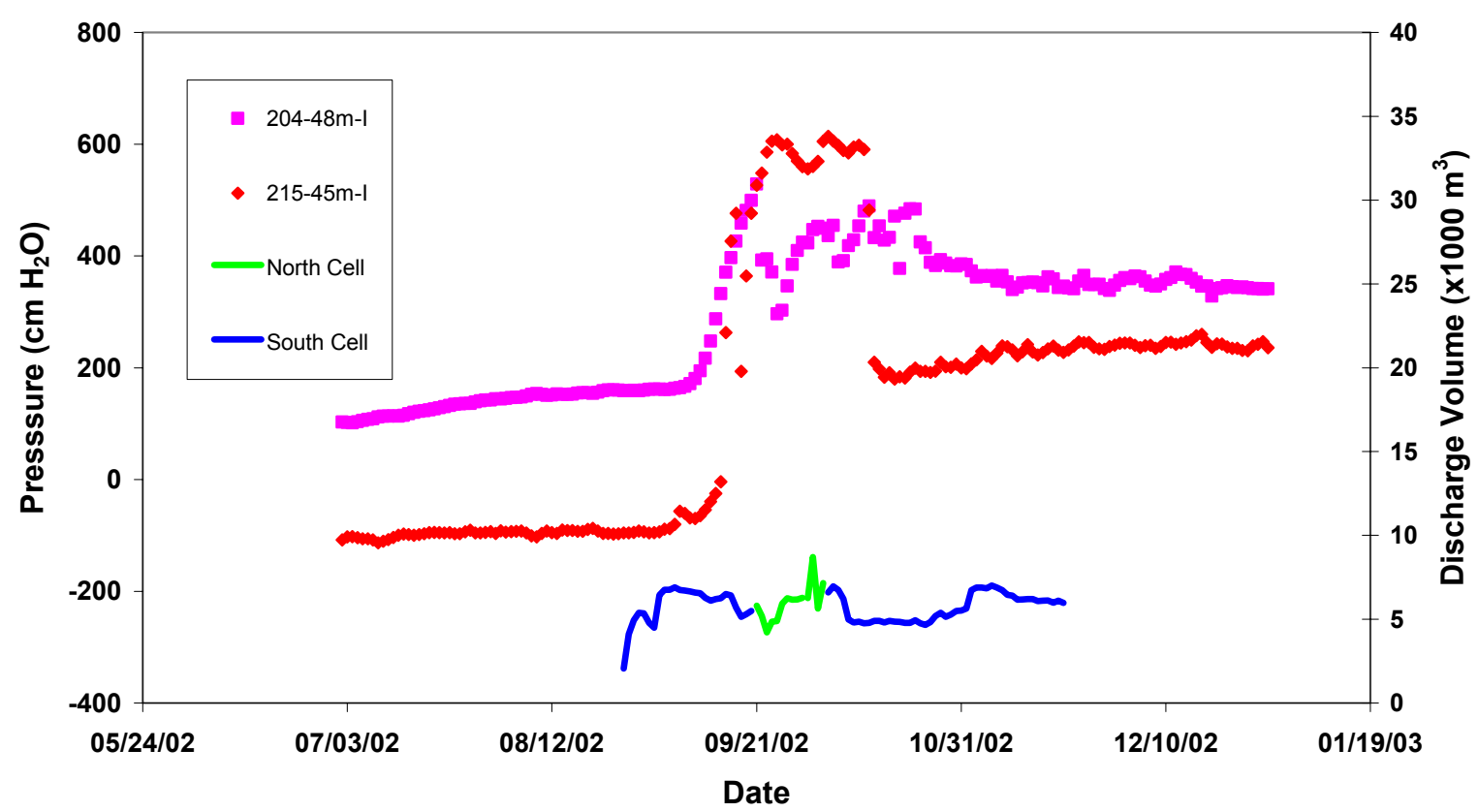

Figure 34. Example of changes in hydraulic pressure possibly due to flushing of fines from large pores during rapid infiltration or encountering fast pathways. Pressure peak reached during initial infiltration for 215 was about 4-m higher than pressure observed after 3 months of continuous discharge to the pond. Pressure peak reached in well 204 was about 1-m higher initially than what was observed 3 months after continuous discharge to the pond. 


\section{Basalt Hydraulic Changes}

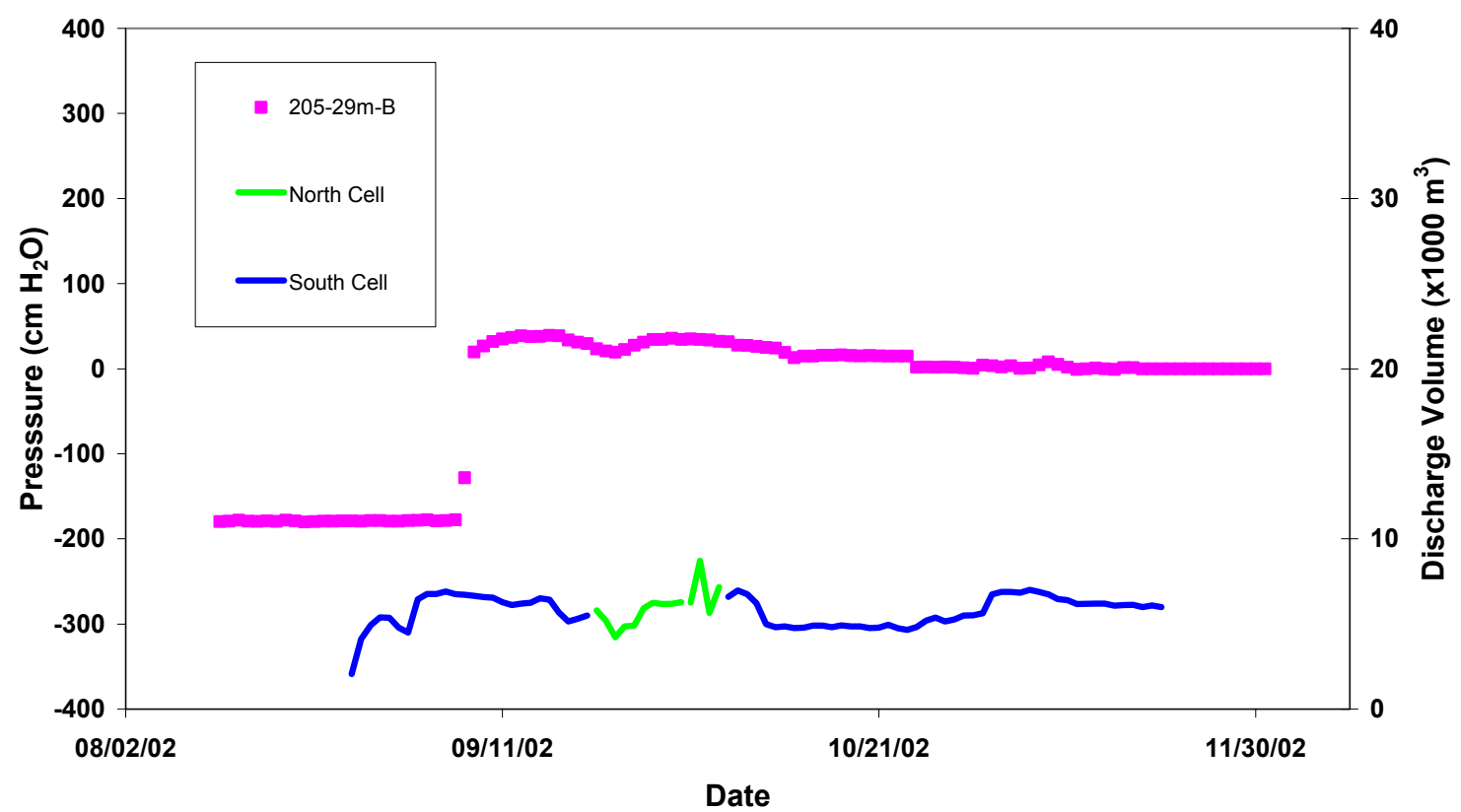

Figure 35. Example of changes in hydraulic pressure possibly due to flushing of fines from large pores during rapid infiltration or encountering fast pathways. Pressure peak reached during initial infiltration was about $1 / 2$ meter higher than pressure observed after 3 months of continuous discharge to the pond (in fact went from positive to negative pressure). 


\section{TABLES (1-2)}

Table 1. Installed wells, completion zones, and uses.

\begin{tabular}{|c|c|c|c|c|c|c|c|}
\hline 4-digit ID & Alias & $\begin{array}{l}\text { Completion } \\
\text { Zone }\end{array}$ & Type & $\begin{array}{l}\text { Completion } \\
\text { Depth }(\mathrm{m})\end{array}$ & Primary Use(s) & $\begin{array}{l}\text { Casing } \\
\text { Material }\end{array}$ & Annular Seal \\
\hline 1383 & 167 & $\mathrm{~A}$ & MON & 153.0 & water quality & SS & granular bentonite \\
\hline 1348 & $164 \mathrm{~A}$ & $\mathrm{~V}$ & MON & 33.5 & perched water & PVC & bentonite slurry \\
\hline 1349 & 164B & A & MON & 162.5 & water quality & SS & bentonite slurry \\
\hline 1350 & $164 \mathrm{C}$ & A & MON & 160.7 & water quality & SS & bentonite slurry \\
\hline 1351 & 165 & A & MON & 160.1 & water quality & SS & granular bentonite \\
\hline 1352 & 166 & A & MON & 160.7 & water quality & SS & granular bentonite \\
\hline 1353 & 187 & $\mathrm{~S}$ & MON & 14.7 & radar & PVC & cement grout \\
\hline 1354 & 188 & $\mathrm{~V}$ & MON & 36.5 & $\begin{array}{l}\text { perched water, } \\
\text { geophysics }\end{array}$ & PVC & bentonite slurry \\
\hline 1415 & 189 & $\mathrm{~V}$ & $\mathrm{SCI}$ & 46.7 & water flux & -- & granular bentonite \\
\hline 1356 & $190 \mathrm{~A}$ & $\mathrm{~S}$ & MON & 12.5 & radar & PVC & cement grout \\
\hline 1357 & 191 & $\mathrm{~V}$ & MON & 36.2 & $\begin{array}{l}\text { perched water, } \\
\text { geophysics }\end{array}$ & PVC & bentonite slurry \\
\hline 1416 & 192 & $\mathrm{~V}$ & SCI & 47.9 & water flux & -- & granular bentonite \\
\hline 1358 & 193 & $\mathrm{~S}$ & MON & 12.3 & $\begin{array}{l}\text { perched water, } \\
\text { geophysics }\end{array}$ & PVC & granular bentonite \\
\hline 1359 & 194 & $\mathrm{~V}$ & MON & 39.0 & $\begin{array}{l}\text { perched water, } \\
\text { geophysics }\end{array}$ & PVC & bentonite slurry \\
\hline 1417 & 195 & $\mathrm{~V}$ & $\mathrm{SCI}$ & 48.8 & water flux & -- & granular bentonite \\
\hline 1360 & 196 & $\mathrm{~S}$ & MON & 17.8 & $\begin{array}{l}\text { perched water, } \\
\text { geophysics }\end{array}$ & PVC & bentonite slurry \\
\hline 1361 & 197 & $\mathrm{~V}$ & MON & 38.1 & $\begin{array}{l}\text { perched water, } \\
\text { geophysics }\end{array}$ & PVC & bentonite slurry \\
\hline 1418 & 198 & $\mathrm{~V}$ & $\mathrm{SCI}$ & 48.5 & water flux & -- & granular bentonite \\
\hline 1362 & 199 & $\mathrm{~S}$ & MON & 15.5 & $\begin{array}{l}\text { perched water, } \\
\text { geophysics }\end{array}$ & PVC & bentonite slurry \\
\hline 1363 & 200 & $\mathrm{~V}$ & MON & 38.7 & $\begin{array}{l}\text { perched water, } \\
\text { geophysics }\end{array}$ & PVC & bentonite slurry \\
\hline 1449 & $201 \mathrm{~A}$ & $\mathrm{~V}$ & GP & 76.2 & geophysics & PVC & cement grout \\
\hline 1365 & $202 \mathrm{~A}$ & $\mathrm{~V}$ & MON & 37.3 & $\begin{array}{l}\text { perched water, } \\
\text { geophysics }\end{array}$ & PVC & bentonite slurry \\
\hline 1366 & 203 & $\mathrm{~S}$ & MON & 15.9 & $\begin{array}{l}\text { perched water, } \\
\text { geophysics }\end{array}$ & PVC & bentonite slurry \\
\hline 1420 & 204 & $\mathrm{~V}$ & $\mathrm{SCI}$ & 53.1 & water flux & -- & granular bentonite \\
\hline 1421 & 205 & $\mathrm{~V}$ & $\mathrm{SCI}$ & 49.5 & water flux & -- & granular bentonite \\
\hline 1422 & 207 & $\mathrm{~V}$ & $\mathrm{SCI}$ & 45.7 & water flux & -- & granular bentonite \\
\hline 1423 & 208 & $\mathrm{~V}$ & MON & 34.7 & $\begin{array}{l}\text { perched water, } \\
\text { geophysics }\end{array}$ & PVC & bentonite slurry \\
\hline
\end{tabular}




\begin{tabular}{|c|c|c|c|c|c|c|c|}
\hline 4-digit ID & Alias & $\begin{array}{l}\text { Completion } \\
\text { Zone }\end{array}$ & Type & $\begin{array}{l}\text { Completion } \\
\text { Depth }(\mathrm{m})\end{array}$ & Primary Use(s) & $\begin{array}{l}\text { Casing } \\
\text { Material }\end{array}$ & Annular Seal \\
\hline 1424 & 209 & V & GP & 76.1 & geophysics & PVC & cement grout \\
\hline 1367 & 210 & $\mathrm{~S}$ & $\mathrm{MON}$ & 18.1 & $\begin{array}{l}\text { perched water, } \\
\text { geophysics }\end{array}$ & PVC & bentonite slurry \\
\hline 1368 & 211 & V & MON & 39.3 & $\begin{array}{l}\text { perched water, } \\
\text { geophysics }\end{array}$ & PVC & bentonite slurry \\
\hline 1425 & 212 & V & MON & 75.7 & geophysics & PVC & cement grout \\
\hline 1369 & 213 & V & GP & 151.1 & geophysics & -- & cement grout \\
\hline 1426 & 214 & V & $\mathrm{SCI}$ & 135.1 & water flux & -- & granular bentonite \\
\hline 1427 & 215 & V & SCI & 147.0 & water flux & -- & granular bentonite \\
\hline 1784 & 1784 & V & MON & 78.0 & geophysics & PVC & bentonite slurry \\
\hline 1785 & 1785 & V & MON & 79.9 & geophysics & PVC & bentonite slurry \\
\hline 1786 & 1786 & V & MON & 79.6 & geophysics & PVC & cement grout \\
\hline 1891 & 1891 & $\mathrm{~S}$ & MON & 5.8 & water quality & PVC & granular bentonite \\
\hline 1892 & 1892 & $\mathrm{~S}$ & MON & 3.5 & water quality & PVC & granular bentonite \\
\hline 1893 & 1893 & $\mathrm{~S}$ & $\mathrm{MON}$ & 2.0 & water quality & PVC & granular bentonite \\
\hline \multicolumn{2}{|c|}{$\mathrm{S}=$ Alluvium } & MON & $=$ Mon & ing well & SS & less steel & \\
\hline \multicolumn{2}{|c|}{$\mathrm{V}=$ Vadose Zone } & SCI & $=$ Inst & nented borehole & $\mathrm{PVC}=$. & vinyl chlc & \\
\hline \multicolumn{2}{|c|}{$\mathrm{A}=$ Aquifer } & GP & $=\mathrm{Geo}$ & ysical borehole & & & \\
\hline
\end{tabular}


Table 2. Water arrival times to various instruments installed at depth near the percolation pond.

\begin{tabular}{|c|c|c|c|c|c|c|c|}
\hline Well ID & $\begin{array}{l}\text { Depth } \\
\text { below } \\
\text { Land } \\
\text { Surface } \\
\quad(\mathrm{m})\end{array}$ & $\begin{array}{l}\text { Initial Head } \\
(\mathrm{cm})\end{array}$ & $\begin{array}{l}\text { First High- } \\
\text { Volume } \\
\text { Discharge Date }\end{array}$ & $\begin{array}{l}\text { First } \\
\text { Response } \\
\text { Date }\end{array}$ & $\begin{array}{c}\text { Travel Time } \\
\text { (days) }\end{array}$ & $\begin{array}{l}\text { Radial } \\
\text { Distance from } \\
\text { Ponds } \\
\qquad(\mathrm{m})\end{array}$ & $\begin{array}{l}\text { Lateral Flow } \\
\text { Velocity } \\
\text { (m/day) }\end{array}$ \\
\hline 198-AT & 32.3 & -115 & $8 / 27 / 02$ & $10 / 06 / 02$ & 46 & 215 & 5 \\
\hline 198-AT & 33.2 & -121 & $8 / 27 / 02$ & $10 / 07 / 02$ & 47 & 215 & 5 \\
\hline 198-AT & 34.4 & -100 & $8 / 27 / 02$ & 09/15/02 & 25 & 215 & 11 \\
\hline 198-AT & 36.9 & -70 & $8 / 27 / 02$ & 09/10/02 & 20 & 215 & 14 \\
\hline 198-AT & 38.1 & 7 & $8 / 27 / 02$ & $09 / 10 / 02$ & 20 & 215 & 14 \\
\hline 198-AT & 42.7 & 103 & $8 / 27 / 02$ & $09 / 15 / 02$ & 25 & 215 & 11 \\
\hline 198-AT & 46.9 & -20 & $8 / 27 / 02$ & no arrival & & 215 & \\
\hline 204-AT & 13.7 & -40 & $8 / 27 / 02$ & $08 / 31 / 02$ & 10 & 120 & 24 \\
\hline 204-AT & 17.7 & -38 & $8 / 27 / 02$ & 08/30/02 & 10 & 120 & 25 \\
\hline 204-AT & 19.2 & -70 & $8 / 27 / 02$ & $08 / 30 / 02$ & 10 & 120 & 25 \\
\hline 204-AT & 27.4 & -64 & $8 / 27 / 02$ & $09 / 02 / 02$ & 12 & 120 & 16 \\
\hline 204-AT & 31.4 & -50 & $8 / 27 / 02$ & $10 / 03 / 02$ & 43 & 120 & 3 \\
\hline 204-AT & 38.7 & -14 & $8 / 27 / 02$ & $09 / 05 / 02$ & 15 & 120 & 12 \\
\hline 204-AT & 45.1 & -25 & $8 / 27 / 02$ & $09 / 02 / 02$ & 12 & 120 & 17 \\
\hline 204-AT & 46.3 & 28 & $8 / 27 / 02$ & 09/09/02 & 19 & 120 & 9 \\
\hline 204-AT & 47.9 & 150 & $8 / 27 / 02$ & $09 / 11 / 02$ & 21 & 120 & 8 \\
\hline 204-AT & 51.2 & 115 & $8 / 27 / 02$ & $09 / 23 / 02$ & 33 & 120 & 4 \\
\hline 205-AT & 15.5 & -60 & $8 / 27 / 02$ & 09/01/02 & 11 & 120 & 20 \\
\hline 205-AT & 16.5 & -65 & $8 / 27 / 02$ & $09 / 02 / 02$ & 12 & 120 & 17 \\
\hline 205-AT & 17.4 & -280 & $8 / 27 / 02$ & 09/03/02 & 13 & 120 & 15 \\
\hline 205-AT & 18.3 & -200 & $8 / 27 / 02$ & 09/03/02 & 13 & 120 & 15 \\
\hline 205-AT & 29.3 & -190 & $8 / 27 / 02$ & 09/07/02 & 17 & 120 & 10 \\
\hline 205-AT & 32.0 & -370 & $8 / 27 / 02$ & 09/14/02 & 24 & 120 & 6 \\
\hline 205-AT & 38.1 & -330 & $8 / 27 / 02$ & $09 / 02 / 02$ & 12 & 120 & 17 \\
\hline 205-AT & 39.0 & -350 & $8 / 27 / 02$ & $09 / 02 / 02$ & 12 & 120 & 17 \\
\hline 205-AT & 40.2 & -190 & $8 / 27 / 02$ & 09/03/02 & 13 & 120 & 15 \\
\hline 205-AT & 44.5 & -75 & $8 / 27 / 02$ & $09 / 29 / 02$ & 39 & 120 & 4 \\
\hline 207-AT & 18.9 & -230 & $8 / 27 / 02$ & Sept & & 129 & \\
\hline 207-AT & 20.4 & -110 & $8 / 27 / 02$ & Sept & & 129 & \\
\hline 207-AT & 28.0 & -15 & $8 / 27 / 02$ & Sept & & 129 & \\
\hline 207-AT & 36.9 & -70 & $8 / 27 / 02$ & Sept & & 129 & \\
\hline 207-AT & 39.3 & -250 & $8 / 27 / 02$ & 07/04/02 & 16 & 129 & 8 \\
\hline 207-AT & 40.8 & -230 & $8 / 27 / 02$ & $07 / 03 / 02$ & 15 & 129 & 9 \\
\hline
\end{tabular}




\begin{tabular}{|c|c|c|c|c|c|c|c|}
\hline Well ID & $\begin{array}{l}\text { Depth } \\
\text { below } \\
\text { Land } \\
\text { Surface } \\
\text { (m) }\end{array}$ & $\begin{array}{l}\text { Initial Head } \\
\quad(\mathrm{cm})\end{array}$ & $\begin{array}{l}\text { First High- } \\
\text { Volume } \\
\text { Discharge Date }\end{array}$ & $\begin{array}{l}\text { First } \\
\text { Response } \\
\text { Date }\end{array}$ & $\begin{array}{l}\text { Travel Time } \\
\text { (days) }\end{array}$ & $\begin{array}{l}\text { Radial } \\
\text { Distance from } \\
\text { Ponds } \\
\qquad(\mathrm{m})\end{array}$ & $\begin{array}{l}\text { Lateral Flow } \\
\text { Velocity } \\
\text { (m/day) }\end{array}$ \\
\hline 207-AT & 44.2 & -130 & $8 / 27 / 02$ & $07 / 24 / 02$ & 36 & 129 & 4 \\
\hline 215-AT & 23.8 & -40 & $8 / 27 / 02$ & 08/30/02 & 3 & 138 & 35 \\
\hline 215-AT & 43.3 & -15 & $8 / 27 / 02$ & 09/08/02 & 12 & 138 & 10 \\
\hline 215-AT & 45.4 & -100 & $8 / 27 / 02$ & 09/13/02 & 17 & 138 & 8 \\
\hline 215-AT & 57.9 & -1 & $8 / 27 / 02$ & $09 / 23 / 02$ & 27 & 138 & 5 \\
\hline 215-AT & 87.2 & 85 & $8 / 27 / 02$ & $10 / 31 / 02$ & 26 & 138 & 2 \\
\hline 215-AT & 101.8 & -85 & $8 / 27 / 02$ & no arrival & & 138 & \\
\hline 215-AT & 146.9 & -5 & $8 / 27 / 02$ & no arrival & & 138 & \\
\hline
\end{tabular}




\section{REFERENCES}

Anderson, S. R. and B. D. Lewis, 1989, Stratigraphy of the Unsaturated Zone at the Radioactive Waste Management Complex Idaho National Engineering Laboratory, Idaho," DOE/ID-22080, U.S. Geological Survey, Water Resources Investigation Report 89-4065, Idaho Falls, Idaho, p. 54.

Arnett, R. C., T. R. Meachum, and P. J. Jessmore, 1996, Post-Record of Decision Monitoring for the Test Reactor Area Perched Water System Operable Unit 2-12, INEL-96/0305, Idaho National Engineering Laboratory, Third Annual Technical Memorandum, Idaho Falls, Idaho,

Arya, L. M., P. J. Feike, P. J. Shouse, and M. T. Van Genuchten, 1999, "Relationship between the Hydraulic Conductivity Function and the Particle-Size Distribution," Soil Science Society of America Journal, Vol. 63, pp. 1063-1070.

Bennett, C. M., 1990, Streamflow Losses and Ground-Water Level Changes Along the Big Lost River at the Idaho National Engineering Laboratory, Idaho, 90-4067, U.S. Geological Survey, WaterResources Investigations Report, Idaho Falls, Idaho, p. 49.

Champion, D.E., Lanphere, M.A., Anderson, S.R., and Kuntz, M.A., 2002, "Accumulation and Subsidence of Late Pleistocene Basaltic Lava Flows of the Eastern Snake River Plain, Idaho," in Geology, Hydrogeology, and Environmental Remediation: Idaho National Engineering and Environmental Laboratory; Snake River Plain, Idaho, edited by P.K. Link and L.L. Mink, Geological Society of America Special Paper 353, Boulder, Colorado, p. 175-192.

Clawson, K. L., G. E. Start, and N. R. Ricks, 1989, Climatography of the Idaho National Engineering Laboratory, 2nd edition, DOE/ID-12118, National Oceanic and Atmospheric Administration, Idaho Falls, Idaho,

DOE/ID, 1999, Final Record of Decision Idaho Nuclear Technology and Engineering Center, Operable Unit 3-13, DOE/ED-10660, Rev. 0, U.S. Department of Energy Idaho Operations Office, Idaho Falls, Idaho,

Dunnivant, F. M., M. E. Newman, C. W. Bishop, D. Burgess, J. R. Giles, B. D. Higgs, J. M. Hubbell, E. R. Neher, G. T. Norrell, M. C. Pfiefer, I. Porro, R. C. Starr, and A. H. Wylie, 1998, "Water and Radioactive Tracer Flow in a Heterogeneous Field-Scale System," Ground Water, Vol. 36 (6), pp. $949-958$.

Faybishenko, B., C. Doughty, M. Steiger, J. C. S. Long, T. R. Wood, J. S. Jacobsen, J. Lore, and P. T. Zawislanski, 2000, "Conceptual Model of the Geometry and Physics of Water Flow a Fractured Basalt Vadose Zone," Water Resources Research, Vol. 36 (12), pp. 3499-3520.

Haverkamp, R. and J. Y. Parlange, 1986, "Predicting the Water-Retention Curve from Particle-Size Distribution: 1. Sandy Soils without Organic Matter," Soil Science, Vol. 142 (6), pp. 325-339.

Hubbell, J. M. and J. B. Sisson, 1998, "Advanced Tensiometer for Shallow or Deep Soil Water Potential Measurements," Soil Science, Vol. 163 (No. 4), pp. 271-277.

Hull, L. C. and C. W. Bishop, 2003, Fate of Magnesium Chloride Brine Applied to Unpaved Roads to Suppress Dust at the Ineel Subsurface Disposal Area, INEEL/EXT-01-01173, Idaho National Engineering and Environmental Laboratory, Bechtel BWXT, Idaho, Idaho Falls, Idaho.

INEEL, 2002, Vadose Zone Instrumented Well and Borehole Installations near the New Intec Percolation Pond Area, End of Well Reports, INEEL/EXT-02-00085, Idaho National Engineering and Environmental Laboratory, Idaho Falls, Idaho. 
Irving, J. S., 1993, Environmental Resource Document for the Idaho National Engineering Laboratory, EGG-WMO-10279, Idaho Engineering and Environmental Laboratory, Technical Report, Idaho Falls, Idaho.

Magnuson, S. O. and A. J. Sondrup, 1998, Development, Calibration, and Predictive Results of a Simulator for Subsurface Pathway Fate and Transport of Aqueous- and Gaseous-Phase Contaminants in the Subsurface Disposal Area at the Idaho National Engineering and Environmental Laboratory, INEEL/EXT-97-00609, Idaho National Engineering and Environmental Laboratory, Idaho Falls, Idaho.

McFadden, P.L. and A. B. Reid, 1982, "Analysis of Paleogagnetic Inclination Data," Journal of the Royal Astronomical Society, 69, pp. 307-319.

Mualem, Y., 1976, "A New Model for Predicting the Hydraulic Conductivity of Unsaturated Porous Media," Water Resources Research, Vol. 12, pp. 513-522.

National Research Council, 2000, Research Needs in Subsurface Science, National Academy Press, Washington, DC, p. 159.

Nimmo, J. R., K. S. Perkins, P. A. Rose, J. P. Rousseau, B. R. Orr, B. V. Twining, and S. R. Anderson, 2002, "Kilometer-Scale Rapid Transport of Naphthalene Sulfonate Tracer in the Unsaturated Zone at the Idaho National Engineering and Environmental Laboratory," Vadose Zone Journal, Vol. 1, pp. 89-101.

Perkins, K. S., 2003, Measurement of Sedimentary Interbed Hydraulic Properties and Their Hydrologic Influence near the Idaho Nuclear Technology and Engineering Center at the Idaho National Engineering and Environmental Laboratory, DOE/ID-22183, U.S. Geological Survey, WaterResources Investigations Report 03-4048, Idaho Falls, Idaho, p. 19.

Reed, M. F., R. C. Bartholomay, and S. S. Hughes, 1997, "Geochemistry and Stratigraphic Correlation of Basalt Lavas beneath the Idaho Chemical Processing Plant, Idaho National Engineering Laboratory," Environmental Geology, Vol. 30, pp. 108-118.

Schafer, A. L., P. Martian, J. M. McCarthy, and T. K. Honeycutt, 1997, "Wag-3 Vadose Zone and Aquifer Ri/Fs Contaminant Source Identification and Fate and Transport Modeling Results," in Comprehensive Ri/Fs for the Idaho Chemical Processing Plant Ou 3-13 at the Ineel - Part a, Ri/Bra Report (Final), DOE/ID-10534, Idaho National Engineering and Environmental Laboratory, Idaho Falls, Idaho.

Sisson, J. B., A. L. Schafer, and J. M. Hubbell, 2000, "Vadose Zone Monitoring System for Site Characterization and Transport Modeling," in Scientific Basis for Nuclear Waste Management XXIII, Boston, Massachusetts, 608, Materials Research Society, pp. 161-166.

Stephens, D. B., 1995, Vadose Zone Hydrology, Boca Raton, Florida: CRC Press, p. 347.

Van Genuchten, M. T., F. J. Leij, and S. R. Yates, 1991, The Retc Code for Quantifying the Hydraulic Functions of Unsaturated Soils, EPA/600/2-91/065, Office of Research and Development, U.S. Environmental Protection Agency, Open File Report, Riverside, California, p. 85.

Vigil, M. J., 1998, "Estimate of Water in Pits During Flooding Events," Project File 3X2MPP130, Idaho National Engineering and Environmental Laborartory, Engineering Design File BWP-12, EG\&G Idaho Inc., Idaho Falls, Idaho.

Winfield, K. A., 2003, Measurement of Unsaturated Hydraulic Conductivity Functions, Saturated Hydraulic Conductivity, Particle-Size Distribution, Bulk Density, Porosity, and Specific Surface Area for the Vadose Zone Research Park Samples, Idaho National Environmental and Engineering Laboratory (INEEL)," in press, U.S. Geological Survey, Water Resources Investigations Report, Menlo Park, California, p. 90. 